ORP-56289

Revision 0

\title{
Final Report - Engineering Study for DWPF Bubblers, VSL-10R1770-1, Rev. 0, dated 12/22/10
}

Prepared for the U.S. Department of Energy

Assistant Secretary for Environmental Management

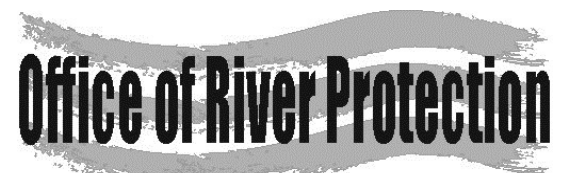

P.O. Box 450

Richland, Washington 99352 
ORP-56289

Revision 0

\title{
Final Report - Engineering Study for DWPF Bubblers, VSL-10R1770-1, Rev. 0, dated 12/22/10
}

\author{
A. A. Kruger \\ Department of Energy - Office of River Protection \\ I. Joseph \\ The Catholic University of America \\ K. S. Matlack \\ The Catholic University of America \\ W. K. Kot \\ The Catholic University of America
}

G. A. Diener

The Catholic University of America

I. L. Pegg

The Catholic University of America

R. A. Callow

The Catholic University of America

Date Published

June 2013

Prepared for the U.S. Department of Energy Assistant Secretary for Environmental Management

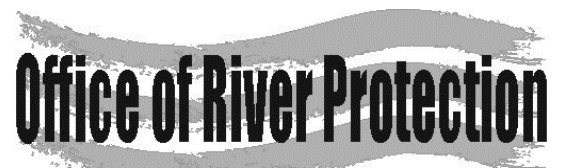

\section{P.O. Box 450}

Richland, Washington 99352

\section{APPROVED}

By Shauna Adams at 10:21 am, Nov 13, 2013 
ORP-56289

Revision 0

TRADEMARK DISCLAIMER

Reference herein to any specific commercial product, process, or service by tradename, trademark, manufacturer, or otherwise, does not necessarily constitute or imply its endorsement, recommendation, or favoring by the United States Government or any agency thereof or its contractors or subcontractors.

This report has been reproduced from the best available copy.

Printed in the United States of America 


\title{
Final Report
}

Engineering Study for DWPF Bubblers

\author{
prepared by
}

\author{
Keith S. Matlack and Ian L. Pegg \\ Vitreous State Laboratory \\ The Catholic University of America \\ Washington, DC 20064 \\ and
}

Richard A. Callow, Innocent Joseph, and Glenn A. Diener

EnergySolutions Federal EPC, Inc.

Columbia, MD

for

\begin{abstract}
Department of Energy
Office of River Protection

Richland, WA 99352
\end{abstract}

September 2, 2010

Rev. 0; 12/22/10 
Document Title: $\quad$ Engineering Study for DWPF Bubblers

\section{Document Number}

and Revision:

Issue Date:

Performing Organization: Vitreous State Laboratory, The Catholic University of America

Contract: "Engineering Study for DWPF Bubblers," Contract \# DE-AC27-07RV14884, Amendment Number A005, 6/8/09.

This report describes the results of work specified by the work scope in the above contract. The work was performed in compliance with the quality assurance requirements specified in the contract. Results required by the contract work scope are reported. This report has been reviewed for correctness, technical adequacy, completeness, and accuracy.

I.L. Pegg:

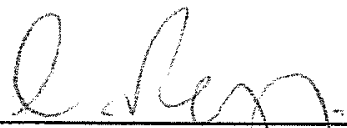

VSL Program Director/Principal Inyestigator

I. Joseph: fronocenftosebt Energy Solutions Sub-Contra of Manager
Date: $\quad 12 / 22 / 60$

Date: $12 / 22 / 10$ 
The Catholic University of America

Vitreous State Laboratory
Engineering Study for DWPF Bubblers Final Report, VSL-10R1770-1, Rev. 0

\section{TABLE OF CONTENTS}

List of Tables

List of Figures

List of Abbreviations

SECTION 1.0 INTRODUCTION

1.1 TEST OBJECTIVES

1.2 QUality Assurance

SECTION 2.0 GLASS THROUGHPUT IMPROVEMENT

2.1 SUMMARY OF GLASS PRODUCTION RATE DATA 10

2.2 GLASS PROdUCTION RATE IMPROVEMENT WITH SimUlated SRS WASTE STREAMS 12

SECTION 3.0 REFRACTORY WEAR 14

3.1 BACKGROUND 14

$\begin{array}{lll}3.2 & \text { DWPF DESIGN } & 14\end{array}$

3.3 VSL LABORATORY CORROSION DATA 15

3.4 M-AREA DM5000A MELTER 16

3.5 LAW PILOT MELTER $\quad 17$

3.6 HLW PILOT MELTER $\quad 18$

$\begin{array}{lll}3.7 & \text { SUMMARY OF REFRACTORY WEAR ASSESSMENT } & 19\end{array}$

SECTION 4.0 POWER REQUIREMENTS

$\begin{array}{ll}\text { SECTION 5.0 POURING STABILITY } & 22\end{array}$

$\begin{array}{ll}\text { SECTION 6.0 REDOX } & 24\end{array}$

SECTION 7.0 OFF-GAS CAPACITY, SOLIDS CARRYOVER, AND CESIUM VOLATILITY 28

SECTION 8.0 SAFETY BASIS AND FLAMMABILITY 31

SECTION 9.0 SUMMARY AND CONCLUSIONS

SECTION 10.0 REFERENCES 35 
The Catholic University of America

Vitreous State Laboratory
Engineering Study for DWPF Bubblers

Final Report, VSL-10R1770-1, Rev. 0

\section{List of Tables}

Table 2.1 Comparison of Production Rates Obtained from Tests With and Without Bubbling. T-1

Table 2.2 Summary of Results from DM100 Tests on SRS Sludge Batch $4 . \quad$ T-2

Table 2.3 Summary of Results from DM100 Tests on SRS Sludge Batch 19 Simulant Prepared by Harrell Industries.

T-3

Table 2.4 Summary of Results from DM100 Tests with SRS Sludge Batch 19 Simulant Prepared by NOAH.

Table 3.1 DWPF Monofrax K-3 Corrosion Allowances. $\quad$ T-5

Table 3.2 DuraMelter 5000A Key Parameters. $\quad$ T-5

Table 3.3 LAW Pilot Melter Key Parameters. $\quad$ T-5

Table 3.4 Summary Comparison of Melters and Bubbler Placements. $\quad$ T-6

Table 4.1 Comparison of Power Used During Tests With and Without Bubbling. $\quad$ T-7

Table 4.2 Summary of Measured DM100 Parameters for Tests with SRS Sludge Batch $4 . \quad$ T-8

Table 4.3 Summary of Measured DM100 Parameters for SRS Sludge Batch 19 Tests. $\quad$ T-9

Table 6.1 Redox State of Glasses. $\quad$ T-10

Table 7.1 Comparison of Particulate and Cesium Carryover during Tests With and Without Bubbling. T-11

Table 7.2 DM100 Melter Off-Gas Emission Results from Tests with SRS Sludge Batch $4 . \quad$ T-12

$\begin{array}{lll}\text { Table 7.3 DM100 Melter Off-Gas Emission Results from Tests with SRS Sludge Batch } 19 & \\ & \text { Simulant Prepared by Harrell Industries. }\end{array}$

Table 7.4 DM100 Melter Off-Gas Emission Results from Tests with SRS Sludge Batch 19 Simulant $\begin{array}{ll}\text { Prepared by NOAH Corporation. } & \text { T-15 }\end{array}$

Table 7.5 DWPF Melter Decontamination Factors for Cesium and Total Particulate. $\quad$ T-16

Table 8.1 Average Concentration and Range (ppmv) of Selected Species in Off-Gas Measured by FTIR Spectroscopy from SRS Sludge Batch 4 DM100 Tests.

Table 8.2 Average Concentration and Range (ppmv) of Selected Species in Off-Gas Measured by FTIR Spectroscopy for SRS Sludge Batch 19 Tests. 
The Catholic University of America

Vitreous State Laboratory
Engineering Study for DWPF Bubblers

Final Report, VSL-10R1770-1, Rev. 0

\section{List of Figures}

Figure 2.1 Comparison of glass production rates with conventional (DWPF and WVDP) and bubbled JHCMs and the further enhancements demonstrated by combining modest operating temperature increases with bubbling.

Figure 2.2 Comparison of glass production rates for Hanford WTP (AZ101, C106/AY102) and West Valley HLW feeds with and without bubbling determined on the DM1000 melter $\left(1.2 \mathrm{~m}^{2}\right)$.

Figure 2.3 Effect of bubbling on glass production rate for a range of Hanford WTP HLW feeds (AZ101, AZ102, C106/AY102, C104/AY101) and feed conditions (solids content, frit, glass formers, nitrated feeds, etc.) determined on two different melters (DM1000 and DM1200, both $1.2 \mathrm{~m}^{2}$ ).

Figure 2.4 Effect of bubbling rate on glass production rate for WTP HLW AZ101 feeds determined on the DM1200 melter $\left(1.2 \mathrm{~m}^{2}\right)$.

Figure 2.5 Results from DM100 test melter campaigns conducted on simulated DWPF feeds.

Figure 2.6 Glass production rates (hourly moving averages) for SRS Sludge Batch 19.

Figure 3.1 DWPF melter lid with bubblers installed (only bubbler assemblies shown).

Figure 3.2 DM-5000A melter K-3 refractory at melt line after a year of operations.

Figure 4.1 Melt pool resistance and total electrode power during processing SRS SB19.

Figure 5.1 Melter Pressure recorded every 2 minutes during DM100 tests with SRS SB19 produced by Harrell Industries.

Figure 5.2 Melter Pressure recorded every 2 minutes during DM100 tests with SRS SB19 simulant produced by Harrell Industries.

Figure 5.3 Melter Pressure recorded every 2 minutes during DM100 tests with SRS SB19 simulant produced by Harrell Industries.

Figure 5.4 Melter Pressure recorded every 2 minutes during DM100 tests with SRS SB19 simulant produced by NOAH.

Figure 6.1 Measured divalent iron concentrations during DM100 tests with SRS SB19 simulant produced by Harrell Industries.

Figure 6.2 Measured divalent iron concentrations during DM100 tests with SRS SB19 simulant produced by NOAH.

Figure 7.1 Measured Carryover from the DM1200 while processing various Hanford simulated HLW streams.

Figure 7.2 Relationship between solids and cesium carryover from the DM1200 while processing Various Hanford simulated HLW streams. 
The Catholic University of America

Vitreous State Laboratory
Engineering Study for DWPF Bubblers

Final Report, VSL-10R1770-1, Rev. 0

\title{
List of Abbreviations
}

\author{
ASME American Society of Mechanical Engineers \\ AZS Alumina-Zirconia-Silica \\ CEF Coldcap Evaluation Furnace \\ DF Decontamination Factor \\ DM DuraMelter ${ }^{\circledR}$ \\ DOE Department of Energy \\ DWPF Defense Waste Processing Facility \\ FTIR Fourier Transform Infrared Spectroscopy \\ HLW High Level Waste \\ IDMS Integrated DWPF Melter System \\ JHCM Joule Heated Ceramic Melter \\ LAW Low-Activity Waste \\ MRF Melt Rate Furnace \\ NQA Nuclear Quality Assurance \\ ORP Office of River Protection \\ QAPjP Quality Assurance Project Plan for Testing Programs Generating Environmental Regulatory Data \\ QAPP Quality Assurance Project Plan \\ QARD Quality Assurance Requirements and Description \\ RPP River Protection Project \\ SB Sludge Batch \\ SME Slurry Mix Evaporator \\ SMRF Slurry-Fed Melt Rate Furnace \\ SRAT Slurry Receipt and Adjustment Tank \\ SRNL Savannah River National Laboratory \\ SRR Savannah River Remediation, LLC \\ SRS Savannah River Site \\ SRTC Savannah River Technology Center \\ SWPF Salt Waste Processing Facility \\ US United States \\ VSL Vitreous State Laboratory \\ WC Water Column \\ WL Waste Loading \\ WTP Hanford Tank Waste Treatment and Immobilization Plant \\ WVDP West Valley Demonstration Project
}


The Catholic University of America

Vitreous State Laboratory
Engineering Study for DWPF Bubblers

Final Report, VSL-10R1770-1, Rev. 0

\section{SECTION 1.0 INTRODUCTION}

The current liquid waste operations contract, held by Savannah River Remediation, LLC (SRR), at the Department of Energy's Savannah River Site (SRS) centers on a number of systemwide process improvements to enhance the efficiency of liquid waste treatment and reduce the lifecycle operational costs. One featured improvement, centers on increasing the waste treatment rate of the Defense Waste Processing Facility's (DWPF) melter operation, whereby the objective of nearly doubling high level waste (HLW) glass canister production to 400 per annum is sought. This goal will be achieved through the transfer of joule heated ceramic melter (JHCM) bubbling technology from the Hanford Tank Waste Treatment and Immobilization Plant (WTP) to the DWPF JHCM. Large-scale testing for the WTP on various melter platforms and over a range of feed compositions has provided data that underpin the ability to achieve the required production rate increase at the DWPF.

In JHCMs, waste and glass forming chemicals or glass frit are fed onto the surface of the molten glass pool to form a "cold cap" region, where a number of process rate controlling physical and chemical reactions occur. As the feed materials travel downward through the cold-cap (vertical melting process), water is evaporated, salts are decomposed and melted, and the products are combined to form molten glass that then becomes part of the underlying pool. The essential melt-rate limiting processes are the transport of heat to and through this zone to fuel the conversion reactions and the mass transport of the reaction products away from this zone. In traditional JHCMs, such as those deployed at the West Valley Demonstration Project (WVDP) and DWPF in the US as well as those deployed in Germany/Belgium and Japan, the electrical energy supplied to the molten glass pool by joule heating is transported to the cold cap region by natural thermal convection, which is relatively inefficient in the viscous glass melt and, in turn, limits mass transport. In the early 1990s, VSL developed an active melt pool mixing technology that employed air sparging or "bubbling" to enhance heat and mass transport and thereby effect dramatic increases in glass production rates. This technology was licensed to EnergySolutions (then Duratek) for further development, demonstration and commercialization. The technology was first deployed at production scale in the EnergySolutions SRS M-Area mixed waste vitrification facility, and is now employed in both the HLW and low active waste (LAW) vitrification melter systems at the Hanford WTP. The experience base with this technology now includes over 11 million pounds of glass produced over many thousands of operating days on five different melter scales ranging from $0.02 \mathrm{~m}^{2}$ melt surface area to $5 \mathrm{~m}^{2}\left(0.02,0.11,1.2,3.3\right.$, and $\left.5 \mathrm{~m}^{2}\right)$, representing a demonstrated scale-up experience by a factor of 250 (for comparison, DWPF has a nominal melt surface area of $2.6 \mathrm{~m}^{2}$ with an effective melt surface area of about $2.3 \mathrm{~m}^{2}$ and the WTP HLW and LAW melters have melt surface areas of $3.75 \mathrm{~m}^{2}$ and 10 $\mathrm{m}^{2}$, respectively). This experience base also spans a very wide range of waste compositions and feed types (HLW and LAW wastes high in iron, sodium, aluminum, chromium, bismuth, sulfate, etc.). Consequently, there is very high confidence in the ability to apply this technology to other waste treatment problems in general, and to DWPF in particular. 
The Catholic University of America

Vitreous State Laboratory
Engineering Study for DWPF Bubblers

Final Report, VSL-10R1770-1, Rev. 0

Applying melt pool bubbling technology at DWPF will not only increase glass production rates but has the potential to affect other aspects of the vitrification process. As production rates increase, so too does the power demand and the challenge presented to the off-gas treatment system. There are other potential impacts in areas such as refractory wear, plenum gas composition and flammability controls, melter pressure control, and glass pouring stability. The purpose of this technical review is to evaluate the potential impacts of employing bubbling technology on the DWPF melter facility based on previous experience with bubbled melter systems. The scope of this engineering review is specified in a Scope of Work issued by The Department of Energy's (DOE) Office of River Protection (ORP) [1].

\subsection{Test Objectives}

As described above, the objective of this work was to perform an engineering assessment of the impact of implementation of bubblers to improve mixing of the glass pool, and thereby increase throughput, in the Defense Waste Processing Facility (DWPF) on the melter and off-gas system. Most of the data used for this evaluation were from extensive melter tests performed on non-SRS feeds. This information was supplemented by more recent results on SRS HLW simulants that were tested on a melter system at VSL under contracts from ORP and SRR [2]. Per the work scope, the evaluation focused on the following areas:

- Glass production rate

- Corrosion of melter components

- Power requirements

- Pouring stability

- Off-gas characteristics

- Safety and flammability

In each area, existing available data were evaluated to address potential impacts on the DWPF, to determine needs where relevant existing data are absent or insufficient, and to recommend testing to address those needs.

It should be noted that although the work scope envisioned active participation by SRS, the information relating to DWPF that was provided for this review was limited. Accordingly, the review is very heavily based on test data collected on bubbled melter systems by EnergySolutions and the Vitreous State Laboratory (VSL) and direct comparisons with DWPF data were possible in limited instances.

\subsection{Quality Assurance}

This review was conducted under a quality assurance program compliant with applicable criteria of 10 CFR 830.120; Office of Civilian Waste Management DOE/RW-0333P, Quality 
The Catholic University of America

Vitreous State Laboratory
Engineering Study for DWPF Bubblers Final Report, VSL-10R1770-1, Rev. 0

Assurance Requirements and Description (QARD) Revision 20; the American Society of Mechanical Engineers (ASME) NQA-1, 2000; and DOE Order 414.1 C, Quality Assurance.

The work is a summary of previously reported test results, the quality assurance requirements for each of which are provided in the original reports. The tests were conducted under a quality assurance program that is in place at the VSL that is based on Nuclear Quality Assurance (NQA)-1 (2004) and NQA-2a (1990) Part 2.7. This program is supplemented by a Quality Assurance Project Plan (QAPP) for ORP work that is conducted at VSL. Test and procedure requirements by which the testing activities are planned and controlled are also defined in this plan. The program is supported by VSL standard operating procedures that were used for this work. This work was not subject to DOE/RW-0333P or the requirements of the River Protection Project (RPP)-WTP Quality Assurance Project Plan for Testing Programs Generating Environmental Regulatory Data (QAPjP). However, several of the original tests were subject to the requirements of the RPP-WTP QAPjP, as noted in the original test reports. 


\section{SECTION 2.0 GLASS THROUGHPUT IMPROVEMENT}

\subsection{Summary of Glass Production Rate Data}

Available data on the impact of bubblers on glass production rates are summarized in a series of figures that are discussed below. The data sets span the history from the first large-scale deployment of the technology at the SRS M-Area vitrification facility through the extensive testing performed for the WTP up to the more recent but more limited tests performed on SRS HLW compositions. The latter data are then discussed in more detail in Section 2.2. In aggregate, these data indicate that achieving glass productions rates corresponding to 400 canisters per year at the DWPF is well within the capability of this technology.

- Figure 2.1 compares melt rates demonstrated with and without bubbling and the further improvements that have been made in the bubbling technology since its first large-scale deployment at the SRS M-Area facility, and shows sample comparative effects of bubbling, glass composition, and melt pool temperature on JCHM production rates. While we would certainly expect lower production rates without bubbling at all temperatures, the tests without bubbling were conducted only at $1150^{\circ} \mathrm{C}$.

- Figure 2.2 shows the impact of bubbling on both West Valley and WTP HLW simulated feed compositions and feed types determined on the DM1000 melter $\left(1.2 \mathrm{~m}^{2}\right)$ [3]. Without bubbling, the DM1000 production rates compare well with those determined using exactly the same simulant during WVDP cold commissioning runs, which provides a valuable calibration check of scale-up effects. Large increases in glass production rates (much greater than 2X) were demonstrated with bubbling across all of the HLW compositions and feed types tested.

- Figure 2.3 shows the impact of bubbling on a wide range of WTP HLW feed compositions and feed types determined on two different $1.2 \mathrm{~m}^{2}$ melters: the DM1000, which operated from about 1994 through 2000 [3], and the DM1200, which has been operating since 2001 [4-10]. The results show that the increase in glass production rate provided by bubblers is both large (much greater than $2 \mathrm{X}$ ) and robust across HLW compositions and feed types. Also evident is the further increase in melt rate that has been demonstrated for the WTP by increasing the number of bubbler outlets [10] (AZ-101 results are at the bottom of Figure 2.3).

- Figure 2.4 shows that for a given melter, bubbler configuration, and feed type, the glass production rate can be varied over a wide dynamic range by simply changing the bubbler flow rate, which is a simple process control setting [6]. This feature of the bubbling technology adds a crucial element of control, flexibility, and robustness that is absent in 
The Catholic University of America

Vitreous State Laboratory

Engineering Study for DWPF Bubblers

Final Report, VSL-10R1770-1, Rev. 0

traditional un-bubbled JHCM systems. This turn-down/turn-up capability allows the user to respond to unanticipated conditions such as slower melting feed types or more dilute feeds via a simple process control setting.

- Figure 2.5 shows specific test results for DWPF simulated waste types (high iron and high aluminum, and one case with simulated SWPF product added) [11]. The tests were also designed to include evaluation of production rate dependence on modest melt pool temperature increase $\left(1150^{\circ} \mathrm{C}\right.$ to $\left.1175^{\circ} \mathrm{C}\right)$. The results from the small-scale test platform (DM100, with a melt pool surface of $0.11 \mathrm{~m}^{2}$ ) were compared to DWPF production scale results without bubbling, which showed that the smaller-scale tests provide a conservative indicator of melter production rate (somewhat lower production rates per unit melt surface area than those found at the production facility). In all cases, with the addition of bubbling, melt rates far surpassing the minimum production rate needed to meet the 400 canister per year production objective $\left(1125 \mathrm{~kg}\right.$ glass $/ \mathrm{m}^{2} /$ day $)$, were observed.

Specific examples of melter throughput in tests conducted on melters at VSL (DM100, DM1000, and DM1200) with and without bubbling are listed in Table 2.1. These melters range in size from a surface area of $0.11 \mathrm{~m}^{2}$ for the DM100 to $1.2 \mathrm{~m}^{2}$ for the DM1000 and DM1200. Glass production rates increased by about 3 to 8 times with melt pool bubbling while processing Hanford and West Valley simulated HLW wastes. Only two bubblers were used in the DM1200 tests; greater increases in production rate were subsequently obtained with double-outlet bubblers and various optimization strategies.

Several general observations are worth noting from these results:

- Bubbling has a dramatic impact on improving convective heat transport to the feed pile or cold cap region during operation. This effect has been demonstrated repeatedly on large scale melters $\left(1.2 \mathrm{~m}^{2}\right.$ to $\left.5.0 \mathrm{~m}^{2}\right)$ and across a diverse range of target glass chemistries and waste types.

- Bubbling can, to a degree, be used as a throttle for melter production rates, by simple adjustment to the rate of bubbling. It should be noted, however, that extreme bubbling rates have diminishing rates of improvement and can increase particulate carryover to the off-gas system (which is typically not observed with appropriately optimized bubbling systems). The effect of bubbling on particulate carryover is discussed in Section 7.

- The glass production rate improvement due to bubbling is so dramatic that it can offset or overshadow lesser effects such as glass chemistry (e.g., intrinsically slow-melting feed chemistries due to increased waste loading, as in the case of high $\mathrm{Al}_{2} \mathrm{O}_{3}$ wastes), or the addition of lid heat (plenum heaters). 
The Catholic University of America

Vitreous State Laboratory
Engineering Study for DWPF Bubblers

Final Report, VSL-10R1770-1, Rev. 0

Additional production rate improvements can be obtained through increases in melt pool operating temperature. The increase in production rate with temperature is dependent on the glass formulation. In bubbled melters, production rate increases of about $1 \%$ per ${ }^{\circ} \mathrm{C}$ increase in temperature for Hanford LAW have been observed and somewhat lower values for Hanford HLW.

\subsection{Glass Production Rate Improvement with Simulated SRS Waste Streams}

During the proposal development stage in support of the SRS Liquid Waste Operations contract, a variety of melter tests were performed at VSL to demonstrate the potential of bubbling technology for throughput enhancement at DWPF [11]. The results from those tests are summarized in Figure 2.5. The effects of a variety of parameters were assessed in those tests; however, two of those tests are directly comparable in that the only difference was the presence or absence of bubbling. Those tests were performed using a projected Sludge Batch 4 (SB4) composition designated as Case 15 Batch 1 of Set 2 in a SRS document [12]. This particular projection of the SB4 sludge composition showed $44.4 \mathrm{wt} \%$ of $\mathrm{Al}_{2} \mathrm{O}_{3}$ along with $17.9 \mathrm{wt} \%$ of $\mathrm{Fe}_{2} \mathrm{O}_{3}$ and $17.7 \mathrm{wt} \%$ of $\mathrm{Na}_{2} \mathrm{O}$ (these tests preceded the processing of Sludge Batch 4 at DWPF and hence the actual Sludge Batch 4 waste composition was different, most notably, much lower in aluminum). The tests were conducted with and without bubbling in the DM100 melter installed at the VSL. The melter feed consisted of the chemical simulant of the SB4 sludge and a frit developed specifically at the VSL to achieve high waste loadings (43 wt $\%$ ) with this very high aluminum sludge composition. The HLW simulant was prepared by mixing chemical simulants to provide the correct oxide and anion compositions, but did not go through the processes to simulant the Slurry Receipt and Adjustment Tank (SRAT) and Slurry Mix Evaporator (SME). The tests were conducted at a nominal melter operating temperature of $1150^{\circ} \mathrm{C}$. Details of the tests are documented in a separate test report [11]. The test parameters are given in Tables 2.2 and 4.2. The results of the test with respect to glass throughput are given in Table 2.2. Without bubbling, the steady-state glass production rate was 450 $\mathrm{kg} / \mathrm{m}^{2} /$ day, whereas with bubbling, the glass production rate increased to $1650 \mathrm{~kg} / \mathrm{m}^{2} /$ day. This increase of about $367 \%$ is within the range observed for other HLW feeds (see Table 2.1). Another test for DOE-ORP discussed below also showed high production rates with bubbling for a Hanford high-Al simulant [13].

Another set of melter tests with projected SRS HLW sludge composition SB19 was recently completed on the DM100 at the VSL $[14,15]$. Major components in the SB19 HLW are $34.3 \mathrm{wt} \%$ of $\mathrm{Al}_{2} \mathrm{O}_{3}, 18.7 \mathrm{wt} \%$ of $\mathrm{Fe}_{2} \mathrm{O}_{3}$ and $27.9 \mathrm{wt} \%$ of $\mathrm{Na}_{2} \mathrm{O}$. Melter tests were conducted with and without bubbling at a nominal operating temperature of $1150^{\circ} \mathrm{C}$. Two different SB19 HLW simulants were used in these tests. One was a chemical simulant prepared by Noah Technologies by mixing the appropriate chemicals to match the oxide and anion compositions of the projected SB19 sludge composition. The other was prepared by Harrell Industries using a preparation process that simulated the SRAT process at DWPF. For the SB19 simulant prepared by Harrell, the acid addition calculation was done by SRR to target a redox ratio $\left(\mathrm{Fe}^{2+} /\right.$ Total $\mathrm{Fe}$ ) of 0.20 (see Section 6 for further discussion on redox). The HLW simulant prepared by Harrell did not simulate the SME process; instead frit was added to the sludge at the VSL. The frit composition was developed by VSL for the 
The Catholic University of America Vitreous State Laboratory

projected high-aluminum SB19 sludge composition [16]. Results of the DM100 melter tests for the two simulants are given in Tables 2.3 and 2.4. The production rate achieved without bubbling for both simulants was $400 \mathrm{~kg}$ glass $/ \mathrm{m}^{2} /$ day, similar to the production rates without bubbling obtained for the SB3 and SB4 simulant. This is illustrated by the comparison of production rates over the course of tests with and without bubbling shown in Figure 2.6. In contrast to other tests, where bubbling was optimized to achieve the maximum steady-state production rate, bubbling while processing the SB19 simulants was adjusted to achieve a production rate of $1125 \mathrm{~kg} / \mathrm{m}^{2} /$ day, which is the production rate needed to produce $400 \mathrm{HLW}$ canisters per year at the DWPF. The target production was easily achieved with a modest bubbling rate. This was observed for both types of waste simulant and while using argon or air as the bubbler gas. Given the modest amount of bubbling used in these tests, higher production rates similar to those obtained while processing the SRS high aluminum composition (Figure 2.5) could be obtained with optimum bubbling. In these tests, per the Test Plan, the objective was to demonstrate achievement of the target rate; no attempt was made to determine the maximum possible production rate, which is expected to be considerably higher (see Figure 2.5). The bubbled test with the NOAH simulant was conducted with one bubbler at an air bubbling rate of $8.5 \mathrm{lpm}$. One of the bubbled tests with the Harrell simulant was conducted at an air bubbling rate of $11.8 \mathrm{lpm}$, while the other was conducted with an argon bubbling rate of $11.9 \mathrm{lpm}$. In contrast, the previous work with the SB4 simulant was conducted at an air bubbling rate of $15.3 \mathrm{lpm}$. The bubbling rates used in these tests are listed in Tables 2.3 and 2.4.

The production rate depends on the bubbling rate and the chemical composition of the feed, in addition to other parameters. Since waste loading (WL) affects chemical composition, WL can have an effect on production rate. However, it is certainly not always true that production rate decreases as WL is increased. Furthermore, the sensitivity of production rate to waste loading and other composition changes is greatly mitigated with bubbling as compared to the case without bubbling. Previous work for the Hanford WTP and DOE-ORP showed that within an acceptable operating range for bubbling rate, production rate increases with increase in bubbling rate. However, the glass and feed compositions also affect production rate and, in fact, production rates even in bubbled melters can be increased substantially by modifying the glass formulation, even at high waste loadings [13]. For example, for a high-Al Hanford HLW, the production rate in a bubbled melter was increased from $550 \mathrm{~kg} / \mathrm{m}^{2} /$ day for a glass with $45 \mathrm{wt} \%$ waste loading $\left(24.6 \mathrm{wt} \% \mathrm{Al}_{2} \mathrm{O}_{3}\right)$ to $1900 \mathrm{~kg} / \mathrm{m}^{2} /$ day for a glass with $50 \mathrm{wt} \%$ waste loading $\left(26.6 \mathrm{wt} \% \mathrm{Al}_{2} \mathrm{O}_{3}\right)$ by redesigning the glass formulation [13]. 
The Catholic University of America

Vitreous State Laboratory
Engineering Study for DWPF Bubblers

Final Report, VSL-10R1770-1, Rev. 0

\section{SECTION 3.0 REFRACTORY WEAR}

\subsection{Background}

This section provides an assessment of the effects of bubbler implementation on refractory wear. The information provided in this section is extracted from the referenced reports. The information to make the assessment is presented as follows:

- Provide basic information on the DWPF melter design, particularly with respect to refractory design and proposed bubbler placement.

- Summarize laboratory data for glass corrosion of K-3 refractory collected at the VSL.

- Summarize and compare melter refractory and bubbler placement designs from previous melters operated by EnergySolutions, and the DM1200 WTP HLW Pilot melter at the VSL. For each melter, provide information available from in-service inspections or post-service dismantling and inspection on the condition of the refractory.

- Provide an overall evaluation of the available information as a basis for assessing the impact of installation of bubblers at the DWPF on refractory life and the likely effects on the overall HLW processing mission at SRS. This requires some consideration of the balance between corrosion in melters with bubblers and increased production rate resulting from agitation.

The increase in glass throughput as a result of melt pool agitation via bubbling has the potential to increase the wear of refractory and other melter components. To assess this, information regarding refractory corrosion from tests conducted at the VSL was evaluated. These data are mostly for glasses developed to support the Hanford Tank Waste Treatment and Immobilization Plant (WTP). Additionally, inspection of the DM1200 at the VSL was periodically performed and included camera inspections of refractory condition. Finally, data are available from previous EnergySolutions melters for the M-Area facility (DM5000A) and the LAW Pilot Melter(DM3300) for the WTP. These melters were used extensively for glass processing and the refractory wear was periodically assessed during melter operations as well as at the end of melter use. Both of the above EnergySolutions melters were decommissioned at the end of service; both melters were taken out of service as a result of mission completion, not melter failure.

\subsection{DWPF Design}

The DWPF melter design corrosion allowances are specified in the design description document [17]. As is the case for the VSL and EnergySolutions melters, the glass contact refractory 
The Catholic University of America

Vitreous State Laboratory
Engineering Study for DWPF Bubblers

Final Report, VSL-10R1770-1, Rev. 0

is Monofrax K-3. The DWPF bottom and side walls are lined with 12 " thick K-3 refractory. This thickness meets the requirements for a 2-year design life based on corrosion allowances (see Table 3.1) given in the DWPF design document [17].

The maximum allowable corrosion of 7.5 mils/day corresponds to corrosion of 2.7 inches of K-3 per 365 days. However, the actual life of the first melter was about 7 years and the second melter has operated for over 7 years. Obviously, the actual refractory corrosion rate is well below the design allowance. Over a period of seven years (2555 days), even complete corrosion/erosion through 12 inches of refractory would correspond to only $12 / 2555=4.7 \times 10^{-3}$ inches $/$ day $=4.7$ mils/day.

The proposed bubbler locations in the DWPF melter are in lid nozzles B1, B2, C2, and C4 (see Figure 3.1). The B1 and B2 bubblers are single function bubblers and are located more centrally in the DWPF melter with bubble injection distances from the refractory of approximately 18 inches. The $\mathrm{C} 2$ and $\mathrm{C} 4$ bubblers are dual function bubblers, which include bubbling and either level detection (C2) or temperature measurement using a thermocouple within a thermowell (C4). Since SRR required that the bubblers be installed using a straight lift, the bubblers are designed to ensure that the injection orifice is as far from the wall as possible to minimize refractory wear. These bubblers are located relatively close to the DWPF refractory wall but the bubble injection is pointed generally away from the wall. Both of the bubble injection points are approximately 5 inches from the wall.

\subsection{VSL Laboratory Corrosion Data}

K-3 refractory corrosion data were collected at laboratory scale for both WTP HLW [18] and Low Activity Waste (LAW) [19] glasses. The glass formulations were designed such that the K-3 corrosion was low enough to achieve the 5-year design life of the WTP HLW and LAW melters. LAW data, summarized in Reference [20], indicate that the estimated corrosion rate for LAW glasses developed for the WTP based on the small-scale tests was about 0.5 inches per year. This rate was verified to be conservative (i.e., predicted corrosion is more than that actually measured at large scale) by inspection of the LAW Pilot Melter during decommissioning [21]. The LAW Pilot Melter was a bubbled melter with a melt surface area of $3.3 . \mathrm{m}^{2}$, and was operated by EnergySolutions for over four years producing over 7.7 million pounds of glass. With optimized bubbling, the production rate of the LAW Pilot Melter was as high as 15,000 lbs of glass per day. The corrosion rate assessment was further supported by comparison of laboratory data and melter inspection results for the second M-Area melter (DM5000A) [22, 23]. The M-Area melter had a melt surface area of $5.0 \mathrm{~m}^{2}$ and included an optimized bubbler system. Laboratory-scale K-3 corrosion test data for HLW glasses show that the majority of them have corrosion rates that are much lower than that of the LAW glasses, which are typically much higher in sodium. This extensive data set on K-3 corrosion rate as a function of glass composition and the linkage to melter life based on inspection of operating and decommissioned melters allows the use of K-3 corrosion tests as a tool in the development of glass formulations. 
The Catholic University of America Vitreous State Laboratory
Engineering Study for DWPF Bubblers

Final Report, VSL-10R1770-1, Rev. 0

\subsection{M-Area DM5000A Melter}

The DuraMelter 5000A (DM5000A) was designed, built and operated by EnergySolutions to immobilize and volume reduce 660,000 gallons of mixed waste at M-Area at the Savannah River Site (SRS). The M-Area waste was similar in composition to the Hanford LAW with a high concentration of sodium and little divalent or trivalent components. The DM5000A was heated to operating temperature in October 1997 and decommissioned in May 1999 after the completion of its mission. During its operating life (December 10, 1997 to January 30, 1999), the DM 5000A melter processed over 1.2 million gallons of feed producing about 2.2 million pounds of glass at an overall plant operating efficiency of $78 \%$.

The general refractory design of the DM5000A was the basis for the LAW Pilot Melter (DM3300) described below, and the current WTP LAW melter design. The DM5000A melter used bubblers to enhance the waste processing rate. The DM5000A was a joule-heated ceramic melter with Inconel 690 electrodes and a melt surface area of $5.0 \mathrm{~m}^{2}$. The key design parameters of the DM5000A are listed in Table 3.2.

The glass contact refractory of the DM5000A was Monofrax ${ }^{\circledR}$ K-3 and Monofrax ${ }^{\circledR}$ E. Monofrax ${ }^{\circledR}$ E was used only in the glass discharge path (the throat and riser block) and for the center electrode support. The refractory was constructed in four layers. The glass contact refractory layer was a 10-inch thick layer of Monofrax K-3. Backing the glass contact layer was a second 5-inch thick layer of Monofrax K-3, followed by two 3-inch layers of Zirmul, a sintered alumina-zirconiasilica (AZS) refractory. The DM5000A bubblers were located approximately 4 inches from the wall $[22]$.

After completion of its mission, the M-Area DM5000A melter was drained in May 1999 and inspected. The inspection of the refractory was only visual without systematic corrosion depth measurements. The inspection showed that the K-3 refractory above the glass line was in excellent shape with little evidence of any corrosion. At the melt line, an approximately 4-inch high ring ranging in depth to as much as one to two inches was noticed (see Figure 3.2). The refractory below the melt line was in excellent condition with visibly sharp block edges. The K-3 refractory located near the bubblers did not show signs of erosion or increased corrosion.

During the destructive examination of the melter, samples were taken of the glass contact refractory. These samples were analyzed by the Savannah River Technology Center (SRTC) to determine the mechanisms of corrosion $[22,23]$. Results showed that corrosion of the K-3 samples appeared to be by the normal mechanisms, i.e. the dissolution of the chromia-alumina solid solution, followed by the slower dissolution of the complex spinel in the interaction layer. It also revealed that glass penetrated into the refractory to a depth of approximately one inch.

In summary, inspection of the DM5000A at the end of its mission showed the refractory package to be in excellent condition with no visible signs of erosion or corrosion due to bubblers. 
The Catholic University of America

Vitreous State Laboratory

Engineering Study for DWPF Bubblers

Final Report, VSL-10R1770-1, Rev. 0

Based on an overall assessment of the refractory condition, EnergySolutions estimated that an additional four to seven years of service lifetime could have been expected for the DM5000A [22]. Independent examination of the refractory samples by SRTC supported the EnergySolutions estimate [23].

\subsection{LAW Pilot Melter}

The DM3300 was designed as a 1/3 section prototype of the WTP LAW melter and had a melt surface area of $3.3 \mathrm{~m}^{2}$, as compared to the $10 \mathrm{~m}^{2}$ area of the full-scale WTP LAW melter [21]. The DM3300 pilot melter began operation on December 30, 1998. Over the next 4.86 years of operation the melter was fed 1,075,395 gallons of simulated LAW feed over a period of 628 days, producing 7,762,393 pounds of glass [21]. The DM3300 was shut down on November 7, 2003 upon completion of its mission and was then disassembled and discarded. Key design parameters for the LAW Pilot melter are listed in Table 3.3.

The refractory was constructed in four layers. The glass contact refractory was a 12-inch thick layer of fused cast Monofrax K-3. Backing the glass contact layer was a second 5-inch thick layer of Monofrax K-3, followed by two 3-inch layers of AZS refractory [24].

The DM3300 used bubbler assemblies comprised of two pipes connected to a bottom manifold that had three bubble release points. The pipes and manifold can be visualized as a very long inverted pi $(\pi)$. The melter used eight bubbler assemblies, six of which were located close to the walls with the closest bubble release point approximately 2 inches nominally from the K-3 refractory. This pattern was used for most, but not all, of the DM3300 operations.

Over its lifetime the DM3300 was inspected several times and these inspections revealed some deterioration and spalling of the K-3 refractory. During the early inspections, some erosion/corrosion of the K-3 refractory was noticed at locations where the bubble release points were closest to the refractory. However, this wear was not clearly visible during the final inspection of the refractory package during dismantling of the melter [21]. It is possible that any early wear was masked by the general corrosion of the refractory package, indicating that the wear on the refractory from bubbling was minimal.

A summary of the refractory corrosion based on in-service inspections and post-service autopsy is provided in a previous report [21]. The major observations from the report are given below.

- $\quad$ The K-3 contact refractory experienced cracking and spalling, especially above the melt line. Approximately $4-5$ inches of refractory was lost above the melt line, and approximately $2-$ 3 inches below the melt line. Possible reasons for the cracking include design of the refractory package with a ledge where feed splashed from the feed tube could potentially 
The Catholic University of America

Vitreous State Laboratory
Engineering Study for DWPF Bubblers

Final Report, VSL-10R1770-1, Rev. 0

accumulate, processing of very high lithium glasses early during its history, and the rough testing performed on the melter (frequent starts and stops, etc.).

- $\quad$ The backup K-3 and AZS refractory were in excellent condition with no refractory loss evident. Some minor glass migration between the K-3 seams and the first layer of AZS was noted. No glass was found in any of the seams on the outer AZS layer.

- $\quad$ The K-3 floor refractory was in excellent condition with less than 1 inch of refractory wear. The backup floor refractory was in excellent condition with some minor glass migration between the refractory seams. No glass was seen in any seam of the outer AZS layer.

- $\quad$ The plenum refractory ( $\mathrm{H}$ brick) was in very good condition with all of the refractory showing some surface cracking. The exposed tuckstone refractory (below the plenum refractory) showed significant cracking and spalling, with an average loss of approximately 5 inches. The tuckstone that was not exposed to the melter plenum was in good condition with only minor surface cracks.

The final inspection showed average K-3 loss of 2-3 inches for all glass contact refractory. Loss of the floor refractory was about one inch. The refractory loss appeared to be related to general corrosion. The final inspection did not show any evidence of enhanced corrosion at the location of the bubblers. If some erosion does occur due to the bubblers, it is likely to be self-limiting since any erosion of the K-3 refractory near the bubbler will effectively increase the distance of the injection point from the wall.

\subsection{HLW Pilot Melter}

The DuraMelter 1200 (DM1200) is the WTP HLW Pilot Melter installed at the VSL. The DM1200 is a joule-heated ceramic melter with Inconel 690 electrodes and a melt surface area of $1.2 \mathrm{~m}^{2}$. The glass contact refractory is Monofrax ${ }^{\circledR} \mathrm{K}-3$ while the plenum area walls are constructed of Monofrax ${ }^{\circledR} \mathrm{H}$ refractory. The DM1200 is an approximate $1 / 3$ scale version of the WTP HLW melter; however, the testing has included extensive processing of both HLW and LAW glasses for the WTP.

The processing history and inspection results concerning the condition of the melter as of 2006 are documented in a VSL summary report [25]. The DM1200 melter has been at temperature for over nine years, during which time over two million pounds of feed were processed to produce over 700,000 pounds of glass. Inspections conducted in 2006 showed that, overall, the melter was in excellent condition after five years of being at operating temperature. The plenum bricks were in excellent condition with some surface cracking. All of the seams between bricks appeared tight with no evidence of significant gaps. The tuckstone showed some minor wear and cracking on the brick faces nearest the glass pool. However, because the DM1200 is still operating, an extensive evaluation of the glass contact K-3 refractory was not possible. The visible parts of the K-3 
The Catholic University of America

Vitreous State Laboratory
Engineering Study for DWPF Bubblers

Final Report, VSL-10R1770-1, Rev. 0

refractory are in good condition and operational information does not indicate any concerns at present. Enhanced corrosion/erosion due to bubblers was not noticed in any of the DM1200 inspections.

\subsection{Summary of Refractory Wear Assessment}

A summary of the observations from a review of the refractory corrosion information from VSL and EnergySolutions is presented in this section. Table 3.4 provides a comparison of the DWPF melter and proposed bubbler configuration with other melters that used bubblers for processing of DOE HLW and LAW feeds. The following observations are noted:

- The DWPF melter and the VSL/EnergySolutions melters are similar in the type of glass contact refractory used (Monofrax K-3) and contact refractory thickness.

- The DWPF melter and the VSL/EnergySolutions melters are all operated at a nominal glass pool temperature of about $1150^{\circ} \mathrm{C}$.

- The DM1200, DM3300, and DM500A bracket the surface area of the DWPF so that scale-up is not an issue.

- If the bubblers are configured properly in the melter, accelerated erosion/corrosion of the refractory due to bubbling is unlikely.

- Accelerated erosion from bubblers placed close to the wall is self-limiting in that refractory erosion increases the distance of the contact refractory from the bubble release point.

- The DM3300 LAW Pilot Melter with bubblers produced over 7.7 million pounds of glass in about 4.8 years before being decommissioned. Despite having processed Hanford LAW, which is, in general, more corrosive to K-3 refractory than HLW feeds, this melter still had several years of useful life left. These results lead to the conclusion that, even at the higher processing rates with bubblers, the melter life was not impacted.

Based on the above information and the fact that the bubble injection points for the DWPF bubblers are farther from the refractory wall than the DM3300 and the DM5000A, it is unlikely that the bubblers will cause any significant erosion of the K-3 contact refractory in the DWPF melter. Little to no erosion is expected on the floor refractory since the bubblers are at least as far from the floor as the bubblers in the DM3300 and the DM5000A. Since glass is produced at a much faster rate with bubblers, the generalized corrosion of glass contact refractory observed in joule-heated ceramic melters would likely be somewhat higher as a function time, but not higher as a function of the amount of glass produced. Review of the information from operation of the VSL/EnergySolutions melters does not show any evidence that enhanced corrosion of the contact refractory due to installation of the bubblers is likely to be the life-limiting factor for DWPF melters. 
The Catholic University of America Vitreous State Laboratory
Engineering Study for DWPF Bubblers Final Report, VSL-10R1770-1, Rev. 0

Over the years VSL/EnergySolutions have developed a database that relates K-3 contact refractory corrosion to glass composition. In addition, the corrosion test results using K-3 refractory coupons can be used to estimate refractory corrosion in operating melters based on information from melters operated by VSL/EnergySolutions. K-3 refractory coupon testing of DWPF glass compositions for HLW processing can be added as an integral part of glass formulation development so that compositions with unacceptably high refractory corrosion rates can be excluded from being selected for HLW processing. 
The Catholic University of America

Vitreous State Laboratory
Engineering Study for DWPF Bubblers

Final Report, VSL-10R1770-1, Rev. 0

\section{SECTION 4.0 POWER REQUIREMENTS}

Since glass pool agitation through bubbling increases glass throughput, there will be a corresponding increase in the power requirements. The anticipated increase in power requirement as the throughput of the DWPF melter is increased through the implementation of bubbling is evaluated here by comparing tests conducted on the melters at VSL (DM100, DM1000, and DM1200) with and without bubbling, as shown in Table 4.1. These are largely the same tests used to evaluate glass production rate in Section 2.2 and include tests processing simulated SRS sludge batches 4 and 19. The increase in electrode power was 1.7 to 3 times greater in tests with bubbling in response to the increases in production rate. The increase in power demand was only about two fold for the SRS sludge batch 19 tests since the increase in production rate was deliberately more modest (i.e., up to the target rate of $1125 \mathrm{~kg} / \mathrm{m}^{2} /$ day); higher power demand would be required for the maximum production rate obtained with optimized bubbling. An illustration of the electrode power demand increase is provided in Figure 4.1 while processing SRS sludge batch 19 with and without bubbling.

The amount of energy consumed per unit time (power demand) increases with glass production rate, as would be expected. Note, however, that the amount of energy consumed per unit mass of glass produced decreases with increasing production rate. As shown in Table 4.1, the amount of energy consumed per unit mass of glass produced is reduced by about a factor of two by using typical bubbling rates and associated increases in glass production rates. The largest decreases correspond to the largest increases in glass production rate, while the lowest decreases were obtained while not maximizing production rate and using plenum heaters. Electrode power serves two purposes: to maintain the temperature of the glass pool and to provide the energy required to incorporate feed components into the glass pool. The latter includes energy used to evaporate water, calcine solids, and melt feed constituents to form new glass, and is therefore proportional to glass production rate. In contrast, the amount of power used to maintain the temperature of the glass pool is essentially constant and therefore constitutes a greater proportion of the total power when processing at low glass production rates.

The use of plenum heaters adds to the total power used in the vitrification process but, when bubblers are employed, does not significantly further increase glass production rates. The primary function of the plenum heaters in the DWPF process is to increase the plenum gas temperatures for flammability control [26-28]. The increase in the plenum temperature as a result of plenum heater use during DM100 melter tests is illustrated by comparing plenum temperatures in Table 4.2 while processing SRS sludge batch 4 without plenum heaters and Table 4.3 while processing SRS sludge batch 19 with plenum heaters. The use of the plenum heaters resulted in about $190^{\circ} \mathrm{C}$ increase in plenum temperature for the plenum heater configuration used. The total power demand for the tests processing the SRS sludge batch 19 increased by $2.5 \mathrm{~kW}$ as a result of using plenum heaters. 
The Catholic University of America

Vitreous State Laboratory
Engineering Study for DWPF Bubblers

Final Report, VSL-10R1770-1, Rev. 0

\section{SECTION 5.0 POURING STABILITY}

The DWPF melter uses a vacuum discharge system, whereas VSL/EnergySolutions melters use air-lift discharges. Therefore, it is not possible to directly compare data from bubbled and unbubbled tests conducted on VSL/EnergySolutions melters to assess the impact of the installation of bubblers on pouring stability in the DWPF melter. However, since pouring stability in the DWPF melter is related to plenum pressure in the melter, the effect of bubbling on plenum pressure is discussed in this section. For this comparison, only the recent test results with SRS simulants on the DM100 melter at the VSL were used since this test is the most relevant for DWPF operation because of the feed type, as well as the amount and type of bubbling $[14,15]$.

DWPF design information (Requirement Basis B.2.4.3.2.2 in Reference [17]) indicates that the DWPF seal pot will activate and release melter off-gas to the cell if the plenum pressure exceeds 2" WC. This set point is required to prevent positive melter plenum pressure from causing an uncontrolled glass discharge. Since the DWPF glass discharge system uses a vacuum pressure difference between the melter plenum and discharge chamber, an increase in plenum pressure can lead to glass discharge. Around the 2008 timeframe, the melter pressure control system was revised for the discharge system to reduce the potential for glass siphoning to the discharge when pressure spikes occur [29]. The control system detects siphoning and increases the melter discharge system pressure quickly enough to stop siphoning, should it initiate.

Plenum pressure fluctuations in melters depend on a number of factors including the type of feed, feed processing rate, bubbling, control air flow, operating pressure (vacuum) in the melter, and melter air in-leakage. In general, the VSL melters operate with more in-leakage and at less of an operating vacuum than the DWPF. Estimated in-leakage flow in the DM1200 is approximately $276 \mathrm{scfm}$ [30]. The in-leakage value for the DWPF is estimated to be $205 \mathrm{lbs} / \mathrm{hr}$ based on test data (Reference [17], Section B1.2.1.6). Using an air density at $70^{\circ} \mathrm{F}$ and 1 atmosphere, this mass in-leakage corresponds to a volume in-leakage rate of approximately $46 \mathrm{cfm}$. This in-leakage amount is substantially less than the DM1200 value even though the DWPF has a melt surface area about double that of the DM1200 $\left(2.6 \mathrm{~m}^{2}\right.$ vs. $\left.1.2 \mathrm{~m}^{2}\right)$.

Melter tests using a projected SRS SB19 HLW simulant composition were recently completed at the VSL $[14,15]$. A total of five test segments, each 50 hours in duration, were conducted. Three of the tests were performed using a simulant prepared by Harrell Industries. Preparation of this simulant followed the SRAT process at the DWPF. The Harrell simulant was used in one test without bubbling, a second test with air bubbling, and a third test with argon bubbling. Two tests were conducted using a SB19 HLW simulant prepared by NOAH Technologies. This simulant was prepared by mixing the appropriate types and amounts of chemicals to match the oxide and anion compositions of the SB19 HLW. One test without bubbling and another test with air bubbling were conducted with the NOAH SB19 simulant. Figures 5.1, 5.2, and 5.3 show melter 
The Catholic University of America Vitreous State Laboratory
Engineering Study for DWPF Bubblers Final Report, VSL-10R1770-1, Rev. 0

pressures from the tests with the Harrell SB19 simulant with air bubbling, without bubbling, and with argon bubbling, respectively. As is evident from the figures, the tests with bubbling show more fluctuation in the melter pressure when compared to the test without bubbling. Figure 5.4 shows melter pressure for the unbubbled test and the test with air bubbling, both using the NOAH simulant. Again, melter pressure fluctuations are larger for the test with bubbling. The differences are likely due simply to the considerably higher rate of feed consumption (and associated decomposition reactions) that results from the higher processing rates that prevail with bubbling. It should be noted, however, that large flow surges of the magnitude typically seen at DWPF $(\sim 12 \mathrm{X})$ have not been observed with bubbled melters.

Although the data show larger pressure fluctuations and generally higher maximum pressures for the bubbled tests as compared to the unbubbled tests, the effect of bubbling on pouring stability in the DWPF melter cannot be directly extrapolated from these DM100 test data because the glass discharge techniques are different. During implementation of bubblers at DWPF, the facility should plan on a higher level of pressure fluctuations in the melter during operations and modify the controls for glass pouring accordingly. While the pressure fluctuations are larger with bubbling, the magnitude of the increase is fairly small $(<2$ " WC), and may not impact pouring stability in the DWPF melter. However, the effect of the impact of bubbling on pouring stability in the DWPF melter will have to be assessed once bubblers are installed in the melter.

In addition to the potential impact of bubbler on pouring stability, there is the potential for increased bubble inclusion in the pour stream and into the glass canister. This effect was assessed by examining glass product samples from the SB19 tests performed on the DM100 with the Harrell simulant using scanning electron microscopy. Samples from both the air bubbled test and from the argon bubbled test showed no significant inclusion of bubbles. A similar question was addressed for glass produced in bubbled DM1200 tests using WTP AZ-101 HLW simulants [31]. However, those tests assessed the total void fraction in 55-gallon drums of glass product. Those tests showed a total void content of about $2.8 \mathrm{vol} \%$. 
The Catholic University of America

Vitreous State Laboratory
Engineering Study for DWPF Bubblers

Final Report, VSL-10R1770-1, Rev. 0

\section{SECTION 6.0 REDOX}

The DWPF operational strategy [32, 33] controls the glass redox $\left(\mathrm{Fe}^{+2} / \mathrm{Fe}_{\text {tot }}\right)$ between 0.09 and 0.33 , with a target of 0.20 . The lower limit (more oxidizing) is intended primarily to protect against foaming and the higher limit (more reducing) protects against formation of metallic and sulfide-rich species that might otherwise drop out of the melt and damage the melter. In addition, for some DWPF frit formulations, the processing rate was found to decrease at redox ratios of less than 0.1 [32]. DWPF uses an algorithm to calculate the amounts of acids to be added to obtain a target glass redox. This algorithm prescribes the amount of formic and nitric acids to be added during feed preparation in order to target a redox ratio of 0.2. Samples of melter feed simulants prepared with this acid addition by the SRAT and SME processes are analyzed for their chemical composition, including anion concentrations. The results from the analysis are used to predict the redox state of the glass using an equation developed by SRNL [33]. The feeds are subsequently melted in closed crucibles and the resultant glass samples are analyzed for redox state to assess the accuracy of the prediction. Glass samples from the Slurry-Fed Melt Rate Furnace (SMRF) and Melt Rate Furnace (MRF) also are analyzed occasionally for their redox state [34]. Very few glass samples from the DWPF melter have been analyzed for redox state. However, a glass sample from the DWPF melter from the SB2 feed was analyzed for its redox state and found to have an $\mathrm{Fe}^{2+} / \mathrm{Fe}$ Total ratio of 0.2 [35], which is the same as the target. The sample was collected to confirm the melt redox conditions after some processing changes such as increase in waste loading and change in frit composition.

Recent tests at the VSL using SRS SB19 simulants (see Section 2 for descriptions of the tests) were used to evaluate the effect of glass pool bubbling on redox state. In parallel with these, a number of closed crucible tests were conducted at the VSL and the Savannah River National Laboratory (SRNL) using SB19 and SB6 HLW feeds. The results of the tests are given in Table 6.1 and Figures 6.1 and 6.2. The acid addition calculation for the SB19 feed simulant was targeted to provide a redox state of 0.2 in terms of $\mathrm{Fe}^{+2} / \mathrm{Fe}_{\text {tot. }}$. Calculation of the predicted redox per the SRNL equation [33] yields a redox ratio of 0.24. However, the glass samples from closed crucible tests were fully oxidized $\left(\mathrm{Fe}^{+2} / \mathrm{Fe}_{\text {tot }}\right.$ of 0.0 or 0.01$)$. DM100 melter samples from tests using SB19 Harrell simulant, without bubbling and with air bubbling, were fully oxidized. Glass samples from the SB19 Harrell simulant processed in the DM100 melter with argon bubbling showed redox state $\left(\mathrm{Fe}^{+2} / \mathrm{Fe}_{\text {tot }}\right)$ values as high as 0.18 (see Figure 6.1). Glass samples from the SB19 NOAH simulant processed in the DM100 melter without bubbling showed $\mathrm{Fe}^{+2} / \mathrm{Fe}_{\text {tot }}$ ratios of up to about 0.05 (see Figure 6.2), whereas the samples from the test with air bubbling were fully oxidized.

Glasses made from SB6 simulants with high noble metals content for which acid additions were made to target a redox ratio of 0.2 were fully oxidized. In addition, SB6 melts, without mercury and noble metals, bubbled with argon in the CEF melter also were fully oxidized. However, an SRNL report [33] shows good agreement between predicted and measured redox ratios for three out of four measurements on SB6 simulants, with all four of the values within the $95 \%$ confidence band of the model. These predictions were based on the analysis of feed samples that had gone through the SRAT and SME processes. 
The Catholic University of America

Vitreous State Laboratory

Engineering Study for DWPF Bubblers

Final Report, VSL-10R1770-1, Rev. 0

The results from the SB19 glass samples, especially the closed crucible test samples prepared using the same procedure that is used at SRNL, do not agree with the prediction regarding redox ratio based on analysis of the feed sample. Contrary to the predicted redox state of 0.24 for the glass product, the feed did not yield measurable amounts of divalent iron in the closed crucible tests. For the SB19 simulant, the closed crucible tests, melter tests with air bubbling, and melter tests without bubbling all gave essentially fully oxidized glasses with the exception of the unbubbled melter test with the NOAH simulant, which showed less than $5 \%$ of $\mathrm{Fe}^{2+}$. In contrast, the DM100 melter test with argon bubbling yielded glass samples with up to $18 \% \mathrm{Fe}^{2+}$, and from Figure 6.1 , it appears that the $\mathrm{Fe}^{2+}$ content of the melt had not reached steady-state by the end of the test, but was still increasing. The single DWPF glass sample from SB2 that was analyzed for redox state [35] showed an $\mathrm{Fe}^{+2} / \mathrm{Fe}_{\text {tot }}$ value of 0.20 and agreed with the results of the closed crucible test. In the case of SB19 Harrell simulant, the closed crucible samples and samples from melter tests without bubbling and with air bubbling show similar redox ratios of zero or close to zero. Therefore, it is reasonable to conclude that bubbling with argon makes the glass melt more reducing as compared to melt processing without bubbling and with air bubbling. The discrepancy between the CEF melter results with argon bubbling and the DM100 melter results with argon bubbling could be due to the differences in the scale and geometry of these systems, with the DM100 system being both larger and more prototypic; however, the specific reasons have not been identified. Furthermore, the DM100 results are consistent with earlier results from melter tests performed at VSL with Hanford LAW simulants in which argon was used as the bubbler gas, which produced a more reduced glass product than was the case when air was used [36].

The SB19 feed simulant prepared by Harrell used in the melter tests did not contain mercury or noble metals, both of which affect chemical reactions in the SRAT, whereas most of the feeds used in the DWPF redox prediction calculation [33] contained these components. The compositions of the SB19 and SB6 simulants also are different, with SB19 having considerably higher aluminum content. SRS selected SB19 HLW for these tests because it is projected to have one of the highest aluminum concentrations of all DWPF feeds and the objective was to determine achievable waste loadings for this feed. Even though these differences can potentially be sources of error in the calculation of the amount of acid to be added to target a specific redox ratio, it should not affect the calculation of redox ratio based on the final feed analysis. The presence of free formic acid in the SB19 SRAT simulant as the reason for the difference is very unlikely given the high $\mathrm{pH}$ of the feed $(\sim 9)$. At this time, the reason for the inability of the model to predict the measured redox ratios for the SB19 SRAT simulant used in these tests is not known.

Although argon is often considered "inert," it necessarily introduces a local low-oxygen environment. When a glass melt is equilibrated with a gas phase (e.g., by gas sparging), it will absorb or take up oxygen as dictated by the underlying redox equilibria. If the gas phase is rich in oxygen, the melt will tend to take up oxygen from the gas and multivalent redox species will tend to move towards their higher oxidation states. Conversely, if the gas phase is poor in oxygen, the melt will tend to give up oxygen to the gas phase and multivalent redox species will tend to move towards their lower oxidation states (i.e., they will be reduced, as is summarized in Le Chatelier's Principle). The equilibrium positions of the redox couples in the glass melt are thus fixed by the oxygen 
The Catholic University of America Vitreous State Laboratory

fugacity in the equilibrium gas phase. Consequently, in terms of the position of these redox couples in general, and that of the $\mathrm{Fe}^{2+} / \mathrm{Fe}^{3+}$ couple in particular, equilibrating the melt with air will necessarily tend to create a lower $\mathrm{Fe}^{2+} / \mathrm{Fe}_{\text {tot }}$ ratio, and equilibration of the melt with argon will tend to create a higher $\mathrm{Fe}^{2+} / \mathrm{Fe}_{\text {tot }}$ ratio. However, in terms of degree of this effect, it is important to note that the redox ratio depends logarithmically on the oxygen fugacity. Consequently, the reducing power of an "oxygen-free" "inert" gas such as argon depends crucially on the trace concentration of oxygen in that gas. These effects have been investigated systematically in borosilicate glasses and extensively documented [36]. Based on Schreiber's data [37], a residual concentration of oxygen of $\sim 5 \mathrm{ppm}$ would give an equilibrium $\mathrm{Fe}^{2+} / \mathrm{Fe}_{\text {tot }}$ ratio of about $20 \%$, whereas $\sim 0.1 \mathrm{ppm}$ would give an equilibrium $\mathrm{Fe}^{2+} / \mathrm{Fe}_{\text {tot }}$ ratio of nearly $40 \%$. It should be noted, however, that these equilibrium conditions will be approached but may or may not be achieved in practice due to the dynamic nature of the actual glass melting process.

DWPF plans to install bubblers in the melter and use argon as the bubbling gas to improve feed processing rate. Since the DM100 melter tests indicate that bubbling with argon is likely to yield a more reducing glass as compared to no bubbling, the DWPF feed preparation strategy should consider this effect. At this time, there are not sufficient data available to predict the exact magnitude of the increase in the redox state of the glass melt with argon bubbling. In the current tests with $\mathrm{SB} 19$, even though a $\mathrm{Fe}^{2+} / \mathrm{Fe}_{\text {tot }}$ ratio of 0.2 was targeted, analysis of multiple glass samples from closed crucible tests and melter tests without bubbling showed redox ratios of zero or close to zero. Bubbling with argon shifted the redox state to about 0.18 . Given that argon bubbling shifted the redox state of an essentially fully oxidized glass $\left(\mathrm{Fe}^{2+} / \mathrm{Fe}_{\text {tot }} \sim 0.0\right)$ to a redox state of about 0.18 , it is likely that if the feed without argon bubbling had yielded the targeted redox state of 0.2 , bubbling with argon would have made the glass yet more reducing. If, for example, these effects were additive, the redox state would be above the DWPF upper redox limit and into the range where formation of deleterious metal and sulfide phases becomes an issue.

In view of the observed differences between targeted and measured redox ratios, limited understanding of the magnitude of the effect of argon bubbling on redox state, and deleterious impacts of over reducing conditions on melter life, it is recommended that during feed preparation, the redox state be targeted towards the oxidizing end of the current operating range to allow for additional reducing impact from argon bubbling.

For future operations at DWPF with argon bubbling, it would be useful to better understand the effect of argon bubbling on glass redox state. This can be accomplished through a combination of crucible-scale tests to determine the magnitude and kinetics of the change in redox state with argon bubbling, a limited number of melter tests to confirm the results from crucible-scale tests in the presence of a cold cap and under the dynamic conditions prevailing in an actual melter of reasonable scale, and analysis of additional samples from the DWPF melter to better understand the actual redox history.

As discussed above, the lower DWPF $\mathrm{Fe}^{2+} / \mathrm{Fe}_{\text {tot }}$ limit of 0.09 is intended to control foaming. It should be noted, however, that experience from the West Valley Demonstration Project (WVDP) and melters operated by EnergySolutions and VSL indicates that foaming can be reliably controlled 
The Catholic University of America Vitreous State Laboratory
Engineering Study for DWPF Bubblers Final Report, VSL-10R1770-1, Rev. 0

even at significantly more oxidizing conditions. In particular, the DM100 melter tests performed with SRS sludge batch 4 and sludge batch 19 simulants showed no issues with foaming despite the fact that the glass was essentially fully oxidized in several cases. This suggests that the DWPF lower limit of 0.09 is overly conservative. 
The Catholic University of America

Vitreous State Laboratory
Engineering Study for DWPF Bubblers

Final Report, VSL-10R1770-1, Rev. 0

\section{SECTION 7.0 OFF-GAS CAPACITY, SOLIDS CARRYOVER, AND CESIUM VOLATILITY}

Implementation of bubbling in the DWPF melter will increase the off-gas flow rate due to factors such as increased throughput and, to a lesser extent, additional gas used for bubbling. In addition, carry-over of feed components, including radioactive cesium, into the off-gas will be affected by bubbling and the increased throughput. The anticipated increase in solids and cesium carryover as the throughput of the DWPF melter is increased through the implementation of bubbling is evaluated here by comparing tests conducted on the melters at VSL (DM100, DM1000, and DM1200) with and without bubbling, as shown in Table 7.1. These are largely the same tests used to evaluate glass production rate in Section 2.2 and electrode power in Section 4.0, and include tests processing simulated SRS sludge batches 4 and 19. Overall, the increase in solids carryover was 1.77 to 8.19 times greater in tests with bubbling, depending greatly on the intensity of bubbling used (as well as the bubbler configuration). In one pair of tests, the carryover without bubbling was actually about half that for the bubbled test based on triplicate measurements for both conditions. In test pairs evaluating carryover increase while processing SRS sludge batch 19 targeting a production rate of $1125 \mathrm{~kg} / \mathrm{m}^{2} /$ day (400 canisters a year) the carryover increase with bubbling is about a factor of two. This condition is closest to being representative of expectations for bubbler deployment at the DWPF; many of the other tests target considerably greater increases in glass production rate and showed correspondingly larger increases in carryover. Tests maximizing the glass throughput with higher relative bubbling rates show the greatest increase in solids carryover as observed in the tests with SRS sludge batch 4 . Similar trends are observed for cesium carryover: 2 to 8 fold increases in cesium carryover were measured in response to bubbling. Increasing the operating temperature is another way to increase production rate. However, with increased temperature, more of the volatiles such as Cs and Tc are likely to be emitted from the melter.

The character of the melter emissions while processing simulated SRS sludge batches 4 and 19 is illustrated in the detailed melter exhaust sampling data given in Tables 7.2 - 7.4. In addition to the increase in carryover with bubbling, the relative volatility of the feed constituents is illustrated. The most volatile feed constituent is rhenium (used as a surrogate for radioactive technetium), with a carryover fraction ranging from about a third to three quarters, depending on melter operating conditions. Reports of DWPF pour sample analyses indicate that the majority of technetium is retained in the glass. However, carryover for technetium of about a third to three quarters is consistent with reports from other vitrification facilities and testing for WTP over a wide range of conditions [36]. A number of studies have shown that more reducing conditions favor technetium retention as a result of the higher volatility of Tc(VII) as compared to $\mathrm{Tc}(\mathrm{IV})$ [36] and that high molar ratios of technetium to cesium can result in increased volatility of cesium [36,38]. Tests have also been performed with WTP LAW simulants to investigate the rate of loss of technetium under melter idling conditions. Those tests showed first-order loss kinetics with a rate constant of about

0.3 hour $^{-1}$, which decreased with decreases in temperature, bubbling rate, and the use of a more 
The Catholic University of America Vitreous State Laboratory
Engineering Study for DWPF Bubblers

Final Report, VSL-10R1770-1, Rev. 0

reducing bubbling gas than air [36]. Tests with Hanford AZ-101 HLW simulants showed ruthenium carryover of about $4 \%$ without bubbling and about $11 \%$ with air bubbling $[39,40]$. Results of those tests also showed decreasing ruthenium carryover with more reducing melt conditions $[39,41]$.

Sulfur is the next most volatile constituent, with six to over seventy-seven percent carryover; however, its determination is complicated by its low concentrations in the SRS sludge batch 4 feed. Cesium carryover ranged from about two and half percent without bubbling to seven percent with bubbling used to obtain maximum production rates. Other feed constituents had lower carryover than rhenium, sulfur, and cesium with the lowest carryover measured for silicon, aluminum, lithium, and zirconium. Potassium, chromium, and boron typically had higher carryover than alkaline earth and transition metals. The amount of water in the exhaust is directly proportional to the feed rate since none of the water is retained in the glass product.

Additional insight into the relationship between bubbling and both solids and cesium carryover can be obtained from analysis of DM1200 emissions data obtained while processing simulated Hanford HLW wastes that contained cesium [25]. Figures 7.1 and 7.2 show all of the available data for cesium and solids carryover from DM1200 tests conducted with cesium-containing Hanford HLW simulants. These data are not from paired tests with and without bubbling but from tests using a variety of Hanford HLW streams, solids contents, feed additives, and bubbling configurations. Without bubbling, solids carryover was less than $0.5 \%$ and increased to as high as $2 \%$ at $65 \mathrm{lpm}$ bubbling (maximum effective bubbling rate for the two-outlet bubbler configuration used). Similarly, cesium carryover increased from less than $1 \%$ to less than $6 \%$, excluding the highest outlier for each condition. Collectively, data from the SRS sludge batch 19 and all of the Hanford HLW tests indicate that even under the most extreme bubbling regimes, cesium carryover is not likely to exceed $8 \%$ and will be significantly less at the more modest bubbling rates planned for the DWPF implementation. As with the various constituents in the SRS wastes during the DM100 tests, cesium carryover increased with solids carryover in the DM1200 tests with the Hanford HLW streams. Overall, as shown in Figure 7.2, cesium carryover is typically about three times that of the total solids carryover. Applying this empirical factor to the data for the DM100 tests using SRS sludge batch 19 feed produced by Harrell Industries would indicate cesium carryover of about 0.3 percent at the target production rate of $1125 \mathrm{~kg} / \mathrm{m}^{2} /$ day with argon bubbling.

Another point of comparison for emissions is data from the operation of the Integrated DWPF Melter System (IDMS), which was a pilot-scale system used in support of start-up and operation of the DWPF [42]. The IDMS had a melt pool surface area of $0.29 \mathrm{~m}^{2}$ (as compared to the full-scale DWPF melter value of $2.6 \mathrm{~m}^{2}$ ), did not use bubbling technology, and used simulated waste spiked with non-radioactive cesium for the emissions tests. Data were reported for carryover and decontamination factors for the melter and for off-gas components. The report [42] also provides the DWPF design values for comparison with IDMS data. Table 7.5 provides the data collected for cesium and particulate carryover from the melter. The measured cesium carryover of $0.76 \%$ in these tests exceeds almost all of the data obtained on melter tests at VSL without bubbling. Also of note is the DWPF DF design value for cesium of 15, which is lower than most of the values measured in melter tests performed at VSL, with the exceptions being those measured at maximum bubbling 
The Catholic University of America Vitreous State Laboratory
Engineering Study for DWPF Bubblers Final Report, VSL-10R1770-1, Rev. 0

rates. Similarly, all particulate DF values from tests with SRS sludge batch 19 at the target production rate of $1125 \mathrm{~kg} / \mathrm{m}^{2} /$ day were higher than the DWPF design DF value of 69 . 


\section{SECTION 8.0 SAFETY BASIS AND FLAMMABILITY}

The safety requirements for the DWFP melter off-gas are documented in the technical safety requirements [43] and design [44] documents. The melter off-gas flammability control discussion and requirements are in Section B 3.3.1 of the technical safety document [43]. Flammability requirements specify the amount of total organic carbon in the feed to the melter, plenum temperature to promote combustion, and off-gas flow. The feed rate to the melter is not directly constrained to a limiting value by the technical safety requirements document; however, it may be indirectly constrained, primarily by other factors such as the lower limit on the plenum temperature.

The justifications for requirements and limitation on feed carbon, melter plenum temperature, and off-gas flow derive from a number of flammability models and calculations [43, 26-28, 45]. The safety requirements are underpinned by a substantial analytical modeling program along with experimental test data. An analytical model was developed to use a four-stage cold-cap decomposition and melting process for the melter feed solids [27]. This model was then evaluated and validated using small-scale data and used with appropriate conservatisms such as assuming an allowable upper bound of gas formation as $60 \%$ of the lower flammability limit under the case of a $3 \mathrm{X}$ off-gas surge. Details of the model validation process are provided in Reference [28]. Initially, a lower temperature bound of $445^{\circ} \mathrm{C}$ was established for the melter plenum. However, additional work since that time has resulted in a somewhat higher plenum temperature value of $493^{\circ} \mathrm{C}$, as documented in the Technical Safety Requirements document [27]. The DWPF safety basis analysis work uses a correlation, based on data, for converting the measured thermocouple reading to a corresponding true gas temperature [28].

The safety basis for the melter feed rate is dependent on maintaining a high enough plenum temperature to promote sufficient combustion. The specific required temperature is determined from an analytical combustion model and the validity of the model is evaluated using small-scale melter test data. The combustion model has been evaluated for both oxidizing and very reducing feeds over a wide temperature range. One of the reports [28] notes that, as of 2000, no off-gas data has been taken from the DWPF melter system to validate calculated off-gas parameters.

Since VSL and EnergySolutions do not have access to the DWPF safety models, it was not possible to perform a flammability and safety analysis. However, off-gas data relevant to safety and flammability are presented in this section. Even though a large database of off-gas data are available at the VSL for bubbled and unbubbled tests, the majority of those data relate to WTP HLW and LAW feeds and are not directly relevant to the DWPF analysis because of differences in feed and melter conditions. The data presented below are from bubbled and unbubbled tests on the DM100 melter at the VSL using simulants of projected SB4 and SB19 HLW compositions.

The off-gas data measured by FTIR for the test with the SB4 HLW simulant prepared by NOAH technologies [11] are given in Table 8.1. The major components in the off-gas were $\mathrm{N}_{2} \mathrm{O}$, $\mathrm{NO}, \mathrm{NO}_{2}, \mathrm{NH}_{3}, \mathrm{H}_{2} \mathrm{O}, \mathrm{CO}_{2}$ and $\mathrm{CO} . \mathrm{H}_{2}$ in the off-gas was not measured for these tests. Test 5 in 
Table 8.1 was conducted with air bubbling and Test 7 without bubbling. The glass production rate was $1650 \mathrm{~kg} / \mathrm{m}^{2} /$ day with air bubbling, and $450 \mathrm{~kg} / \mathrm{m}^{2} /$ day without bubbling. As the glass production rate increased 3.7 times, the concentrations of NOx emissions from the melter increased by a factor of about 3.4 or less and the concentration of $\mathrm{CO}$ increased by a factor of 2.9.

The off-gas data measured by FTIR for the test with SB19 HLW simulants [14, 15] are given in Table 8.2. The major components in the off-gas were $\mathrm{N}_{2} \mathrm{O}, \mathrm{NO}, \mathrm{NO}_{2}, \mathrm{NH}_{3}, \mathrm{H}_{2} \mathrm{O}, \mathrm{CO}_{2}$ and $\mathrm{CO}, \mathrm{HF}$ and $\mathrm{H}_{2}$. Test 1 in Table 8.2 was conducted with air bubbling and the Harrell simulant, Test 2 without bubbling and the Harrell simulant, Test 3 with argon bubbling and the Harrell simulant, Test 4 with air bubbling and the NOAH simulant, and Test 5 without bubbling and the NOAH simulant. The Harrell simulant went through the SRAT process, whereas the NOAH simulant was prepared by mixing the appropriate chemicals to achieve the same final oxide composition. With air and argon bubbling the glass production rate was $1200 \mathrm{~kg} / \mathrm{m}^{2} /$ day with the Harrell simulant, and $400 \mathrm{~kg} / \mathrm{m}^{2} /$ day without bubbling. With air bubbling, the glass production rate was $1125 \mathrm{~kg} / \mathrm{m}^{2} /$ day with the NOAH simulant and $400 \mathrm{~kg} / \mathrm{m}^{2} /$ day without bubbling.

With the Harrell simulant, as the glass production rate increased by a factor of three, the concentrations of various NOx species emitted from the melter increased by factors of between 1.5 and 3.5 and $\mathrm{CO}$ emissions increased by factors of between 1.7 and 2.3. $\mathrm{H}_{2}$ emissions from the melter increased by a factor of 1.4 with air bubbling, but decreased more than $10 \%$ with argon bubbling.

With the NOAH simulant, as the glass production rate increased by a factor of 2.8 , the concentrations of various NOx species emitted from the melter increased by factors of between 1.5 and 2.2 and $\mathrm{CO}$ emissions increased by a factor of 2.4. $\mathrm{H}_{2}$ emissions from the melter increased by a factor of 1.8 with air bubbling.

The concentration of flammable gases and NOx in the off-gas from the melter increased as the feed rate was increased with bubbling. However, the increases in the concentrations of $\mathrm{H}_{2}$ and $\mathrm{CO}$ in the melter off-gas were by factors that were significantly smaller than those for the increase in feed rate. 


\section{SECTION 9.0 SUMMARY AND CONCLUSIONS}

An engineering assessment of the impact of implementation of bubblers to improve mixing of the glass pool, and thereby increase throughput, in the Defense Waste Processing Facility (DWPF) on the melter and off-gas system was performed. Data from a vast array of melter tests conducted by EnergySolutions and the Vitreous State Laboratory on Hanford and West Valley wastes simulants, as well as a series of melter tests conducted on SRS Sludge batches 4 and 19 provided input for this assessment. The existing available data were evaluated to address potential impacts on the DWPF, to determine needs where relevant existing data are absent or insufficient, and to recommend testing to address those needs. The following specific areas were investigated: Glass production rate; corrosion of melter components; power requirements; pouring stability; offgas characteristics; and safety and flammability. The review indicates that, overall, bubbling can be implemented safely to improve melter throughput to the design requirement glass production rate of 400 canisters annually. Uncertainty still exists in areas of glass redox state control and the effects of argon bubbling, the extent to which pressure fluctuations may affect pouring stability, and any effects on flammability control, which is the subject of a separate assessment by SRR. The following provides a summary of the findings for each area that was reviewed:

- Glass Throughput - Bubbling technology has been demonstrated to increase glass throughput by 3 to 7 times for various HLW as well as LAW streams. Tests with SRS sludge batch 4 simulants have demonstrated a nearly four-fold increase with bubbling. Tests with SRS sludge batch 19 have demonstrated that a production rate of $1125 \mathrm{~kg} / \mathrm{m}^{2} /$ day, which corresponds to the DWPF target of 400 canisters per year, can be achieved with modest bubbling. Although the DWPF melter design throughput is about 400 canisters per year, that rate has not yet been achieved.

- Refractory Wear - While the higher glass throughput that results from bubbling will result in some increase in refractory wear, extensive testing has shown that, when properly deployed, the increase in refractory wear due to bubbling is small. Melters that have been operational for many years with bubbling at high throughput, and frequently used much more corrosive glass compositions, indicate lifetimes in excess of five years. Coupon tests have been developed to estimate melter refractory life for prospective glass compositions.

- Power Requirements - Power demand increases with throughput while the energy consumption per unit amount of glass produced decreases. Melter testing indicates that increasing the glass production rate with bubbling to the design throughput requirement of 400 canisters would result in an approximate two-fold increase in instantaneous power demand.

- Pouring Stability - Melter pressure fluctuations increase somewhat as a result of the increased throughput produced by bubbling. Pouring stability has not been an issue for the air-lift melter systems employed in the melter used by EnergySolutions and VSL. However, 
any potential impact on the vacuum pouring system employed in the DWPF melter still needs to be assessed.

- Redox - The predicted [33] redox states of SB19 feed simulants without mercury and noble metals do not agree with those measured in closed crucible tests and melter tests, both of which show more oxidized glasses than predicted. Melter tests conducted with Ar bubbling result in a more reducing glass product than without bubbling or with air bubbling. The combined impact of these uncertainties remains to be assessed.

- Off-gas Capacity and Solids and Cesium Carryover - Solids and cesium carryover increase with increasing bubbling and production rate. The increases in carryover associated with achieving the throughput of 400 canisters per year result in DFs that are still greater than the DWPF DF design value. Most tests conducted at VSL with Hanford HLW simulants also resulted in measured melter DF values above the DWPF design specification.

- Safety Basis/Flammability - The concentrations of $\mathrm{CO}$ and $\mathrm{H}_{2}$ increase with throughput; however, the factors by which they increase are significantly smaller than the factor by which throughput increases. The plenum temperature, which is a controlled parameter for mitigating flammable gases, is maintained with plenum heaters and therefore does not change with melt pool bubbling. Using argon as the bubbling gas resulted in smaller increases in $\mathrm{H}_{2}$ and $\mathrm{CO}$ concentrations as compared to air bubbling.

Additional data and review from DWPF could alleviate some of the uncertainty remaining related to the implementation of bubblers at DWPF. Specific areas are as follows:

- Confirmation of the actual amount of power available to electrodes in the DWPF melter.

- Threshold for pressure fluctuations for pouring stability.

- The effect of higher $\mathrm{CO}$ and $\mathrm{H}_{2}$ concentrations on flammability as defined by the model used at DWPF.

- Measured carryover of solids and cesium from the DWPF melter. 


\section{SECTION 10.0 REFERENCES}

[1] "Engineering Study for DWPF Bubblers," Contract Number DE-AC27-07RV14884, US Department of Energy, Office of River Protection, Richland, WA, 2007. Amendment A005 dated $4 / 28 / 09$.

[2] ORP Contract No. DE-AC27-07RV14884, "Savannah River Site (SRS) Workscope," Department of Energy, Office of River Protection, Richland, WA; and SRR SOW RQ0000006 Change Notice Number Six under Sub-Contract No. C002402P, Savannah River Remediation, LLC, Aiken, SC.

[3] "Determination of Processing Rate of RPP-WTP HLW Simulants using a DuraMelterTM 1000 Vitrification System," K.S. Matlack, W.K. Kot, F. Perez-Cardenas, and I.L. Pegg, VSL-00R2590-2, Rev. 0, Vitreous State Laboratory, The Catholic University of America, Washington, DC, 8/21/00.

[4] "Start-Up and Commissioning Tests on the DM1200 HLW Pilot Melter System Using AZ101 Waste Simulants," K.S. Matlack, M. Brandys, and I.L. Pegg, Final Report, VSL01R0100-2, Rev.1, Vitreous State Laboratory, The Catholic University of America, Washington, DC, 10/31/01.

[5] "Tests on the DuraMelter 1200 HLW Pilot Melter System Using AZ-101 HLW Simulants," K.S. Matlack, W.K. Kot, T. Bardakci, T.R. Schatz, W. Gong, and I.L. Pegg, Final Report, VSL-02R0100-2, Rev. 0, Vitreous State Laboratory, The Catholic University of America, Washington, DC, 6/11/02.

[6] “DM1200 Tests with AZ-101 HLW Simulants,” K.S. Matlack, W. Gong, T. Bardakci, N. D'Angelo, W.K. Kot, and I.L. Pegg, Final Report, VSL-03R3800-4, Rev. 0, Vitreous State Laboratory, The Catholic University of America, Washington, DC, 2/17/04.

[7] "Integrated DM1200 Melter Testing of HLW AZ-102 Compositions Using Bubblers," K.S. Matlack, W. Gong, T. Bardakci, N. D’Angelo, W. Kot and I.L. Pegg, Final Report, VSL03R3800-2, Rev. 0, Vitreous State Laboratory, The Catholic University of America, Washington, DC, 9/24/03.

[8] "Integrated DM1200 Melter Testing of HLW C-106/AY-102 Composition Using Bubblers," K.S. Matlack, W. Gong, T. Bardakci, N. D’Angelo, W. Kot and I.L. Pegg, Final Report, VSL-03R3800-1, Rev. 0, Vitreous State Laboratory, The Catholic University of America, Washington, DC, 9/15/03. 
[9] "Integrated DM1200 Melter Testing of HLW C-104/AY-101 Compositions Using Bubblers," K.S. Matlack, W. Gong, T. Bardakci, N. D’Angelo, W. Kot and I.L. Pegg, Final Report, VSL-03R3800-3, Rev. 0, Vitreous State Laboratory, The Catholic University of America, Washington, DC, 11/24/03.

[10] "Integrated DM1200 Melter Testing of Bubbler Configurations Using HLW AZ-101 Simulants," K.S. Matlack, W. Gong, T. Bardakci, N. D’Angelo, W. Lutze, R. A. Callow, M. Brandys, W.K. Kot, and I.L. Pegg, Final Report, VSL-04R4800-4, Rev. 0, Vitreous State Laboratory, The Catholic University of America, Washington, DC, 10/5/04.

[11] "SRS Vitrification System Improvements," K.S. Matlack, W. Kot, W. Gong and I.L. Pegg, Final Report, VSL-07R1270-1, Rev. 0, Vitreous State Laboratory, The Catholic University of America, Washington, DC, June 30, 2007.

[12] "Sludge Batch 2/3 Blend SRAT Cycle in the SRNL Shielded Cells," C. J. Bannochie, J.M. Pareizs, and D. C., Koopman, WSRC-RP-2004-00097, Revision 0, Westinghouse Savannah River Company, Aiken, SC, May 2004.

[13] "DM100 and DM1200 Melter Testing with High Waste Loading Glass Formulations for Hanford High-Aluminum HLW Streams," K.S. Matlack, H. Gan, M. Chaudhuri, W. Kot, W. Gong, T. Bardakci, I.L. Pegg, and I. Joseph, Final Report, VSL-10R1690-1, Rev. 0, Vitreous State Laboratory, The Catholic University of America, Washington, DC, 8/16/10.

[14] "Glass Formulation Development and Testing for DWPF High- $\mathrm{Al}_{2} \mathrm{O}_{3}$ HLW Sludges," K.S. Matlack, W.K. Kot, I.L. Pegg, and I. Joseph, Test Plan, VSL-09T1670-1, Rev. 0, Vitreous State Laboratory, The Catholic University of America, Washington, DC, 6/4/09.

[15] "Testing to Assess the Impact of Argon vs. Air as a Bubbler Gas For the DWPF High- $\mathrm{Al}_{2} \mathrm{O}_{3}$ HLW Sludges," K.S. Matlack, W.K. Kot, I.L. Pegg, and I. Joseph, Test Plan, VSL-09T16701, Rev. 0, Vitreous State Laboratory, The Catholic University of America, Washington, DC, $6 / 4 / 09$.

[16] "Glass Formulation Development and Testing for DWPF High- $\mathrm{Al}_{2} \mathrm{O}_{3}$ HLW Sludges" W.K. Kot and I.L. Pegg, Data Summary Report, VSL-10S1670-1, Rev. 0, Vitreous State Laboratory, The Catholic University of America, Washington, DC, 4/19/10.

[17] "Defense Waste Processing Facility System Design Description (U), Melter \& Assoc Equipment, GP-2," G-SYD-S-0060, Rev 3, Westinghouse Savannah River Company, Aiken, SC, April 2005.

[18] "Corrosion of K-3 Refractory and Metal Alloys in RPP-WTP HLW Glasses," H. Gan, X.D. Lu, I. Vidensky, M.C. Paul, and I.L. Pegg, Final Report, VSL-01R2550-1, Rev. 0, Vitreous State Laboratory, The Catholic University of America, Washington, DC March, 2001. 
[19] "Corrosion of K-3 Refractory and Metal Alloys in RPP-WTP LAW Glasses," H. Gan, X.D. Lu, I. Vidensky, M.C. Paul, and I.L. Pegg, Final Report, VSL-01R3540-1, Rev. 0, Vitreous State Laboratory, The Catholic University of America, Washington, DC March, 2001.

[20] "RPP-WTP Pilot Melter - Melter Life Interim Test Results Report," C.P. Payne, TRR-PLT05B, Rev 0, Duratek, Inc., Columbia, MD, April, 2001.

[21] “RPP-WTP LAW Pilot Melter Disassembly Report," G. Diener, REP-PLT-026, Rev 0, Duratek, Inc., Columbia, MD, February, 2004.

[22] "Savannah River Site M-Area Sludge Vitrification Project Summary of Operations and Preliminary Evaluation of the DuraMelter 5000A Addendum: Summary of Melter Draining and Additional Inspection,” Internal Duratek Memorandum, November 1999.

[23] "BNFL Report Inspection of M-Area, GTS Duratek, Melter Refractories," Letter Report, BNF-003-98-0136 revision 0, September 27, 1999.

[24] "Refractory Corrosion Analysis for the DM-5000A and LAW Pilot Melters," C.C. Chapman, REP-PLT-015, Rev 0, Duratek, Inc., Columbia, MD, December, 2003.

[25] "Summary of DM1200 Operations at VSL", K.S. Matlack, G. Diener, T. Bardakci, and I.L. Pegg, Final Report, VSL-06R6710-2, Rev. 0, Vitreous State Laboratory, The Catholic University of America, Washington, DC, 9/7/06.

[26] "Minimum TI4085D Interlock Setpoint at 1.0 GPM Sludge-Only Feed Rate and 14,000 TOC (U)," A.S. Choi, WSRC-TR-96-0357-TL, Westinghouse Savannah River Company, Aiken, $\mathrm{SC}$.

[27] "Maximum Total Organic Carbon Limit for DWPF Melter Feed (U)", A.S. Choi, WSRCTR-95-0119, Westinghouse Savannah River Company, Aiken, SC, March 1995.

[28] "Validation of DWPF Melter Off-Gas Combustion Model", A.S. Choi, WSRC-TR-200000100, Westinghouse Savannah River Company, Aiken, SC, 2000.

[29] "Recent Process and Equipment Improvements to Increase High Level Waste Throughput at the Defense Waste Processing Facility (DWPF)", R.J. O’Driscoll, A.B. Barnes. J.R. Coleman, T.L Glover, R.C. Hopkins, D.C. Iverson, J.N. Leita, WM2008 Conference Proceedings, February 2008.

[30] "Comparison of Off-Gas Emissions from Tests with LAW Simulants on the DM100, DM1200, and DM3300 Melters," R.A. Callow, K.S. Matlack, and I.L. Pegg, Summary Report, VSL-04S4850-1, Vitreous State Laboratory, The Catholic University of America, Washington, DC, 4/19/04. 
[31] “Air Bubbles in DM1200, Simulated AZ-101 HLW Glass,” W. Gong, K.S. Matlack and I.L. Pegg, Letter Report, VSL-03L3800-1, Rev. 0, Vitreous State Laboratory, The Catholic University of America, Washington, DC, 1/31/2003.

[32] "Role of Manganese Reduction/Oxidation (Redox) on Foaming and Melt Rate in High Level Waste (HLW) Melters (U)", C.M Jantzen, and M.E. Stone, WSRC-STI-2006-00066, Rev 0, Savannah River National Laboratory, Aiken, SC, March 2007.

[33] "Defense Waste Processing Facility (DWPF) Sludge Batch 6 (SB6) Redox Evaluation," J.D. Newell, SRNL-L3100-2010-00073, Savannah River National Laboratory, Aiken, SC, June, 2010.

[34] "Sludge Batch 4 Baseline Melt Rate Furnace and Slurry-Fed Melt Rate Furnace Tests with Frits 418 and 510," M.E. Smith, T.M. Jones, and D.H. Miller, WSRC-STI-2007-00450, Savannah River National Laboratory, Aiken, SC, September, 2007.

[35] "Characterization of Defense Waste Processing Facility (DWPF) Glass and Deposit Samples from Melter \#2 (U)”, C.M. Jantzen, A.D. Cozzi, and N.E. Bibler, WSRC-TR-2003-00502, Rev. 0, Savannah River Technology Center, Aiken, SC, 3/1/04.

[36] "Improving Technetium Retention in Hanford LAW Glass - Phase 1," K.S. Matlack, I.S. Muller, I. Joseph, and I.L. Pegg, Final Report, VSL-10R1920-1, Rev. 0, Vitreous State Laboratory, The Catholic University of America, Washington, DC, 3/19/10.

[37] "An Electrochemical Series of Redox Couples in Silicate Melts: A Review and Application s of Geochemistry,” H. D. Schreiber, J. Geophys. Res., 92, 9225 (1987).

[38] "DM100 HLW and LAW Tests of the Influence of Technetium on Cesium Volatility Using Rhenium as a Technetium Surrogate," K.S. Matlack, W.K. Kot, and I.L. Pegg, Final Report, VSL-04R4710-1, Rev. 0, Vitreous State Laboratory, The Catholic University of America, Washington, DC, 9/28/04.

[39] "Integrated DM1200 Melter Testing of Bubbler Configurations Using HLW AZ-101 Simulants," K.S. Matlack, W. Gong, T. Bardakci, N. D'Angelo, W. Lutze, R.A. Callow, M. Brandys, W.K. Kot, and I.L. Pegg, Final Report, VSL-04R4800-4, Rev. 0, Vitreous State Laboratory, The Catholic University of America, Washington, DC, 10/5/04.

[40] "Testing and Modeling the Behavior of Platinoids during Vitrification of High-Level Radioactive Waste - Part 1,” W. Lutze, W. Gong, F.C. Perez-Cardenas, K.S. Matlack, I.L. Pegg, and P. Schill, European J. Glass Sci. Tech., 48, 263 (2007).

[41] "Testing and Modeling the Behavior of Platinoids During Vitrification of High-Level Radioactive Waste, Part 3," W. Gong, W. Lutze, K.S. Matlack, and I.L. Pegg, European J. Glass Sci. Tech., 50, 95 (2009). 
[42] "Measurement of Cesium Emissions during Vitrification of Simulated High Level Radioactive Waste", J.R. Zamencnik, D.H. Miller, and J.T. Carter, WSRC-MS-92-251, Westinghouse Savannah River Company, Aiken, SC, 1992.

[43] “Technical Safety Requirements Defense Waste Processing Facility," WSRC-TS-95-0019, S-TSR-S-00001, Westinghouse Savannah River Company, Aiken, SC.

[44] "Defense Waste Processing Facility, System Design Description (U) Melter Off-Gas System," G-SYD-S-0061, Rev 5, GP-03, Westinghouse Savannah River Company, Aiken, SC, February, 2008.

[45] "Maximum Organic Carbon Limits at Different Melter Feed Rates," A.S. Choi, WSRC-TR95-0294, Westinghouse Savannah River Company, Aiken, SC, 1995. 
Table 2.1. Comparison of Production Rates Obtained from Tests With and Without Bubbling.

\begin{tabular}{|c|c|c|c|c|}
\hline Melter & Feed & $\begin{array}{l}\text { Bubbling } \\
\text { (lpm) }\end{array}$ & $\begin{array}{c}\text { Production Rate } \\
\left(\mathrm{kg} / \mathrm{m}^{2} / \text { day }\right)\end{array}$ & $\begin{array}{c}\text { Rate Increase from } \\
\text { Bubbling }\end{array}$ \\
\hline \multirow{2}{*}{ DM100 } & \multirow{2}{*}{ AZ-101 [12] } & $<0.1 \mathrm{lpm}$ & 430 & \multirow{2}{*}{$302 \%$} \\
\hline & & $5.7 \mathrm{lpm}$ & 1300 & \\
\hline \multirow{4}{*}{ DM1000 } & \multirow{2}{*}{ C-106/AY-102 [3] } & 0 & 160 & \multirow{2}{*}{$781 \%$} \\
\hline & & 61-97 lpm & 1250 & \\
\hline & \multirow{2}{*}{ West Valley [3] } & 0 & $250-350$ & \multirow{2}{*}{$391 \%$} \\
\hline & & Yes & 1370 & \\
\hline \multirow{6}{*}{ DM1200 } & \multirow{2}{*}{ AZ-101 [4] } & $<4$ lpm & 155 & \multirow{2}{*}{$484 \%$} \\
\hline & & $47 \mathrm{lpm}$ & 750 & \\
\hline & \multirow{2}{*}{ AZ-101 + frit [5] } & $<4 \mathrm{lpm}$ & 210 & \multirow{2}{*}{$524 \%$} \\
\hline & & $60 \mathrm{lpm}$ & 1100 & \\
\hline & \multirow{2}{*}{ AZ-101 [6] } & $<4 \mathrm{lpm}$ & 190 & \multirow{2}{*}{$395 \%$} \\
\hline & & $65 \mathrm{lpm}$ & 750 & \\
\hline
\end{tabular}


Table 2.2. Summary of Results from DM100 Tests on SRS Sludge Batch 4.

\begin{tabular}{|c|c|c|c|}
\hline \multicolumn{2}{|r|}{ Test } & 5 & 7 \\
\hline \multirow{3}{*}{$\underset{\Xi}{\Xi}$} & Feed Start & 2/22/07 2:00 & 2/23/07 2:00 \\
\hline & Feed End & 2/23/07 2:00 & 2/24/07 2:00 \\
\hline & Interval & $24.0 \mathrm{hr}$ & $24.0 \mathrm{hr}$ \\
\hline \multicolumn{2}{|c|}{ Water Feeding for Cold Cap } & NA & NA \\
\hline \multicolumn{2}{|r|}{ Slurry Feeding } & $24.0 \mathrm{hr}$ & $24.0 \mathrm{hr}$ \\
\hline \multicolumn{2}{|c|}{ Feeding Interruptions } & $10 \mathrm{~min}$ & $27 \mathrm{~min}$ \\
\hline \multicolumn{2}{|r|}{ Cold cap burn } & NA & $1.9 \mathrm{hr}$ \\
\hline \multicolumn{2}{|c|}{ Plenum Heaters } & OFF & OFF \\
\hline \multicolumn{2}{|c|}{ Target Glass Temperature } & $1150^{\circ} \mathrm{C}$ & $1150^{\circ} \mathrm{C}$ \\
\hline \multicolumn{2}{|c|}{ Average Bubbling Rate } & $15.3 \mathrm{lpm}$ & $0.3 \mathrm{lpm}$ \\
\hline \multirow{2}{*}{ 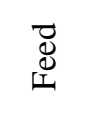 } & Used & $495 \mathrm{~kg}$ & $129 \mathrm{~kg}$ \\
\hline & Average Feed Rate & $20.6 \mathrm{~kg} / \mathrm{hr}$ & $5.4 \mathrm{~kg} / \mathrm{hr}$ \\
\hline \multirow{3}{*}{ 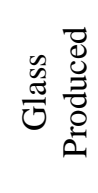 } & Poured & $172 \mathrm{~kg}$ & $44 \mathrm{~kg}$ \\
\hline & Average Rate ${ }^{*}$ & $1604 \mathrm{~kg} / \mathrm{m}^{2} /$ day & $418 \mathrm{~kg} / \mathrm{m}^{2} /$ day \\
\hline & Steady State Rate ${ }^{*}$ & $1650 \mathrm{~kg} / \mathrm{m}^{2} /$ day & $450 \mathrm{~kg} / \mathrm{m}^{2} /$ day \\
\hline
\end{tabular}

$\$$ - Rates calculated from glass poured.

*- Rates calculated from feed data.

Note: Rates do not take into account the time for water feeding and cold cap burn-off. Production rates not calculated from amounts of poured glass due to the changing of the level of glass in the melter. 
ORP-56289 Rev. 0

The Catholic University of America

Table 2.3. Summary of Results from DM100 Tests with SRS Sludge Batch 19 Simulant Prepared by Harrell Industries.

\begin{tabular}{|c|c|c|c|c|}
\hline \multicolumn{2}{|r|}{ Test } & 1 & 2 & 3 \\
\hline \multirow{3}{*}{ 音 } & Feed Start & 6/2/10 23:52 & 6/9/10 00:00 & 6/16/10 08:30 \\
\hline & Feed End & 6/5/10 2:00 & 6/11/10 2:30 & 6/18/10 11:15 \\
\hline & Interval & $50.1 \mathrm{hr}$ & $50.5 \mathrm{hr}$ & $50.75 \mathrm{hr}$ \\
\hline \multicolumn{2}{|c|}{ Water Feeding for Cold Cap } & $0.5 \mathrm{hr}$ & $0 \mathrm{hr}$ & $0.75 \mathrm{hr}$ \\
\hline \multicolumn{2}{|c|}{ Slurry Feeding } & $49.6 \mathrm{hr}$ & $50.5 \mathrm{hr}$ & $50.0 \mathrm{hr}$ \\
\hline \multicolumn{2}{|c|}{ Feeding Interruptions } & $136 \mathrm{~min}$ & $14 \mathrm{~min}$ & $40 \mathrm{~min}$ \\
\hline \multicolumn{2}{|c|}{ Cold cap burn } & $1.6 \mathrm{hr}$ & $1.9 \mathrm{hr}$ & $1.3 \mathrm{hr}$ \\
\hline \multicolumn{2}{|c|}{ Plenum Heaters } & $\mathrm{ON}$ & ON & ON \\
\hline \multicolumn{2}{|c|}{$\begin{array}{c}\text { Average Measured Plenum } \\
\text { Temperature }\end{array}$} & $675^{\circ} \mathrm{C}^{\&}$ & $632^{\circ} \mathrm{C}$ & $688^{\circ} \mathrm{C}$ \\
\hline \multicolumn{2}{|c|}{ Target Glass Temperature } & $1150^{\circ} \mathrm{C}$ & $1150^{\circ} \mathrm{C}$ & $1150^{\circ} \mathrm{C}$ \\
\hline \multicolumn{2}{|c|}{$\begin{array}{c}\text { Average Measured Bulk Glass } \\
\text { Temperature }\end{array}$} & $1149^{\circ} \mathrm{C}^{\&}$ & $1155^{\circ} \mathrm{C}$ & $1150{ }^{\circ} \mathrm{C}$ \\
\hline \multirow{3}{*}{ Bubbling } & Gas & Air & None & Argon \\
\hline & Target Rate & $\begin{array}{l}\text { To achieve glass production } \\
\text { rate of } 1150 \mathrm{~kg} / \mathrm{m}^{2} / \text { day }\end{array}$ & 0 & $\begin{array}{c}\text { To achieve glass } \\
\text { production rate of } \\
1150 \mathrm{~kg} / \mathrm{m}^{2} / \text { day }\end{array}$ \\
\hline & Average Rate & $11.8 \mathrm{lpm}^{\&}$ & $0 \mathrm{lpm}$ & $11.9 \mathrm{lpm}$ \\
\hline \multirow{2}{*}{ Feed } & Used & $705 \mathrm{~kg}$ & $288 \mathrm{~kg}$ & $712 \mathrm{~kg}$ \\
\hline & $\begin{array}{l}\text { Average Feed } \\
\text { Rate }\end{array}$ & $14.2 \mathrm{~kg} / \mathrm{hr}$ & $5.7 \mathrm{~kg} / \mathrm{hr}$ & $14.2 \mathrm{~kg} / \mathrm{hr}$ \\
\hline \multirow{5}{*}{ Glass } & Poured & $279.5 \mathrm{~kg}$ & $74.7 \mathrm{~kg}$ & $257.5 \mathrm{~kg}$ \\
\hline & Average Rate $\$$ & $1252 \mathrm{~kg} / \mathrm{m}^{2} /$ day & $329 \mathrm{~kg} / \mathrm{m}^{2} /$ day & $1144 \mathrm{~kg} / \mathrm{m}^{2} /$ day \\
\hline & Average Rate & $1134 \mathrm{~kg} / \mathrm{m}^{2} /$ day & $450 \mathrm{~kg} / \mathrm{m}^{2} /$ day & $1133 \mathrm{~kg} / \mathrm{m}^{2} /$ day \\
\hline & $\begin{array}{l}\text { Estimated Steady } \\
\text { State Rate }\end{array}$ & $1200 \mathrm{~kg} / \mathrm{m}^{2} / \mathrm{day}^{\&}$ & $400 \mathrm{~kg} / \mathrm{m}^{2} /$ day & $1200 \mathrm{~kg} / \mathrm{m}^{2} /$ day \\
\hline & $\begin{array}{c}\text { Measured \%Fe++/ } \\
\text { Total Fe }\end{array}$ & $<1$ & $<1$ & 18 \\
\hline
\end{tabular}

$\$$ - Rates calculated from glass poured. *- Rates calculated from feed data.

$\&$ - Value calculated from portion test conducted after feed diluted to $45 \%$ solids.

Note: Rates do not take into account the time for water feeding and cold cap burn-off. 
Table 2.4. Summary of Results from DM100 Tests with SRS Sludge Batch 19 Simulant Prepared by NOAH.

\begin{tabular}{|c|c|c|c|}
\hline \multicolumn{2}{|r|}{ Test } & 4 & 5 \\
\hline \multirow{3}{*}{$\stackrel{\mathscr{G}}{\Xi}$} & Feed Start & 7/12/10 9:30 & 7/14/10 12:30 \\
\hline & Feed End & 7/14/10 12:00 & 7/16/10 20:00 \\
\hline & Interval & $50.5 \mathrm{hr}$ & $55.5 \mathrm{hr}$ \\
\hline \multicolumn{2}{|c|}{ Water Feeding for Cold Cap } & $0.5 \mathrm{hr}$ & $0 \mathrm{hr}$ \\
\hline \multicolumn{2}{|c|}{ Slurry Feeding } & $50.0 \mathrm{hr}$ & $55.5 \mathrm{hr}$ \\
\hline \multicolumn{2}{|c|}{ Feeding Interruptions } & $\min$ & $\min$ \\
\hline \multicolumn{2}{|c|}{ Cold cap burn } & NA & $1.8 \mathrm{hr}$ \\
\hline \multicolumn{2}{|c|}{ Plenum Heaters } & ON & ON \\
\hline \multicolumn{2}{|c|}{$\begin{array}{c}\text { Average Measured Plenum } \\
\text { Temperature }\end{array}$} & $685^{\circ} \mathrm{C}$ & $679^{\circ} \mathrm{C}$ \\
\hline \multicolumn{2}{|c|}{ Target Glass Temperature } & $1150^{\circ} \mathrm{C}$ & $1150^{\circ} \mathrm{C}$ \\
\hline \multicolumn{2}{|c|}{$\begin{array}{c}\text { Average Measured Bulk Glass } \\
\text { Temperature }\end{array}$} & $1151^{\circ} \mathrm{C}$ & $1154^{\circ} \mathrm{C}$ \\
\hline \multirow{3}{*}{ Bubbling } & Gas & Air & None \\
\hline & Target Rate & $\begin{array}{l}\text { To achieve glass production } \\
\text { rate of } 1150 \mathrm{~kg} / \mathrm{m}^{2} / \text { day }\end{array}$ & 0 \\
\hline & Average Rate & $8.5 \mathrm{lpm}$ & $0 \mathrm{lpm}$ \\
\hline \multirow{2}{*}{ Feed } & Used & $755 \mathrm{~kg}$ & $287 \mathrm{~kg}$ \\
\hline & $\begin{array}{l}\text { Average Feed } \\
\text { Rate }\end{array}$ & $15.1 \mathrm{~kg} / \mathrm{hr}$ & $5.2 \mathrm{~kg} / \mathrm{hr}$ \\
\hline \multirow{5}{*}{ Glass } & Poured & $260.1 \mathrm{~kg}$ & $93.5 \mathrm{~kg}$ \\
\hline & Average Rate ${ }^{\$}$ & $1145 \mathrm{~kg} / \mathrm{m}^{2} /$ day & $371 \mathrm{~kg} / \mathrm{m}^{2} /$ day \\
\hline & Average Rate ${ }^{*}$ & $1124 \mathrm{~kg} / \mathrm{m}^{2} /$ day & $385 \mathrm{~kg} / \mathrm{m}^{2} /$ day \\
\hline & $\begin{array}{l}\text { Estimated Steady } \\
\text { State Rate }\end{array}$ & $1125 \mathrm{~kg} / \mathrm{m}^{2} / \mathrm{day}^{\&}$ & $400 \mathrm{~kg} / \mathrm{m}^{2} /$ day \\
\hline & $\begin{array}{c}\text { Measured \%Fe++/ } \\
\text { Total Fe }\end{array}$ & $<1$ & 4.6 \\
\hline
\end{tabular}

$\$$ - Rates calculated from glass poured.

*- Rates calculated from feed data.

Note: Rates do not take into account the time for water feeding and cold cap burn-off. 
Table 3.1. DWPF Monofrax K-3 Corrosion Allowances.

\begin{tabular}{|c|c|}
\hline Location & Corrosion Allowance \\
\hline Sidewall above melt line & 3 mils/day \\
\hline $\begin{array}{c}\text { Sidewall 0-4” below melt } \\
\text { line }\end{array}$ & 7.5 mils/day \\
\hline $\begin{array}{c}\text { Sidewall greater than 4" } \\
\text { below melt line }\end{array}$ & 5.4 mils/day \\
\hline
\end{tabular}

Table 3.2. DuraMelter 5000A Key Parameters.

\begin{tabular}{|l|l|}
\hline Parameter & Value \\
\hline \hline Glass pool length (distance between electrodes) & $4^{\prime}$ (each side) \\
\hline Glass pool width & $5^{\prime}-10^{\prime \prime}$ \\
\hline Glass pool depth & $22^{\prime}$ \\
\hline Plenum height & $4^{\prime}-0^{\prime \prime}$ \\
\hline Glass temperature & $1150^{\circ} \mathrm{C}$ \\
\hline Plenum temperature (not feeding) & $\sim 1100^{\circ} \mathrm{C}$ \\
\hline Plenum temperature (feeding) & $\sim 400^{\circ} \mathrm{C}$ \\
\hline Lid heaters & $\sim 70 \mathrm{~kW}$ \\
\hline Number of bubbler assemblies & $10^{*}$ \\
\hline \hline
\end{tabular}

(*Value corrected from report.)

Table 3.3. LAW Pilot Melter Key Parameters.

\begin{tabular}{||l|l||}
\hline \hline Parameter & Value \\
\hline \hline Glass pool length (distance between electrodes) & $6{ }^{\prime}-8^{\prime \prime}$ \\
\hline Glass pool width & $5 ’-4 ”$ \\
\hline Glass pool depth & $2^{\prime}-9^{\prime \prime}$ \\
\hline Plenum height & $4^{\prime}-0^{\prime \prime}$ \\
\hline Glass temperature & $1150^{\circ} \mathrm{C}$ \\
\hline Plenum temperature (not feeding) & $\sim 1100^{\circ} \mathrm{C}$ \\
\hline Plenum temperature (feeding) & $350-450^{\circ} \mathrm{C}$ \\
\hline Lid heaters & No lid heaters \\
\hline Number of bubbler assemblies & 8 \\
\hline \hline
\end{tabular}


Table 3.4. Summary Comparison of Melters and Bubbler Placements.

\begin{tabular}{|c|c|c|c|c|}
\hline Parameter & DWPF & DM5000A & DM3300 & DM1200 \\
\hline Geometry & Cylinder & Rectangular & Rectangular & Rectangular \\
\hline Melt surface area, $\mathrm{m}^{2}$ & 2.6 & 5.0 & 3.3 & 1.2 \\
\hline Glass contact refractory type & K-3 & K-3 & K-3 & K-3 \\
\hline $\begin{array}{l}\text { Glass contact refractory } \\
\text { thickness, in }\end{array}$ & 12 & 10 & 12 & 5 \\
\hline Number of bubblers & 4 assemblies & 10 assemblies & 8 assemblies & $\begin{array}{c}\text { Varies } \\
2-6 \\
\text { (typically) }\end{array}$ \\
\hline $\begin{array}{l}\text { Closest distance from bubbler } \\
\text { injection point to refractory } \\
\text { wall, in }\end{array}$ & $\sim 5$ & $\sim 4$ & $\sim 2$ & $\begin{array}{l}\text { Varies } \\
\sim 3-8\end{array}$ \\
\hline $\begin{array}{l}\text { Closest distance from the } \\
\text { bubbler injection point to floor } \\
\text { refractory, in }\end{array}$ & $>2$ & 2 & 2 & $1-2$ \\
\hline Total glass produced, lb & $2,963,000 *$ & $2,175,000$ & $7,762,000$ & $633,000 * *$ \\
\hline
\end{tabular}

* Estimated value for first DWPF melter at 6.3 years of operation.

** Approximate value as of 3/05. 
Table 4.1. Comparison of Power Used During Tests With and Without Bubbling.

\begin{tabular}{|c|c|c|c|c|c|c|c|}
\hline Melter & Feed & $\begin{array}{l}\text { Bubbling } \\
\text { (lpm) }\end{array}$ & $\begin{array}{c}\text { Electrode } \\
\text { Power } \\
(\mathrm{kW})\end{array}$ & $\begin{array}{c}\text { Plenum } \\
\text { Heater } \\
\text { Power } \\
(\mathrm{kW})\end{array}$ & $\begin{array}{c}\text { Total } \\
\text { Power } \\
(\mathrm{kW})\end{array}$ & $\begin{array}{c}\text { Average } \\
\text { Energy Use } \\
\text { (kW.hr/ } \\
\text { kg glass) }\end{array}$ & $\begin{array}{c}\text { Decrease in } \\
\text { Energy } \\
\text { Required to } \\
\text { Produce Glass } \\
\text { Attributable to } \\
\text { Bubbling } \\
\end{array}$ \\
\hline \multirow{2}{*}{ DM100 } & \multirow{2}{*}{ AZ-101 [12] } & $<0.1$ & 15.7 & 0 & 15.7 & 8.4 & \multirow{2}{*}{$48 \%$} \\
\hline & & 5.7 & 36.9 & 0 & 36.9 & 4.4 & \\
\hline \multirow{4}{*}{ DM1000 } & \multirow{2}{*}{$\begin{array}{c}\text { C-106/AY- } \\
102[3] \\
\end{array}$} & 0 & 64 & 0 & 64 & 8.0 & \multirow{2}{*}{$61 \%$} \\
\hline & & $61-97$ & 193 & 0 & 193 & 3.1 & \\
\hline & \multirow{2}{*}{$\begin{array}{c}\text { West Valley } \\
{[3]}\end{array}$} & 0 & 72.1 & 0 & 72.1 & 4.7 & \multirow{2}{*}{$43 \%$} \\
\hline & & Yes & 170.4 & 0 & 170.4 & 2.7 & \\
\hline \multirow{6}{*}{ DM1200 } & \multirow{2}{*}{ AZ-101 [4] } & $<4$ & 78 & 0 & 78 & 9.8 & \multirow{2}{*}{$63 \%$} \\
\hline & & 47 & 135 & 0 & 135 & 3.6 & \\
\hline & \multirow{2}{*}{$\begin{array}{c}\text { AZ-101 + frit } \\
{[5]}\end{array}$} & $<4$ & 74 & 0 & 74 & 6.0 & \multirow{2}{*}{$45 \%$} \\
\hline & & 60 & 160 & 0 & 160 & 3.3 & \\
\hline & \multirow{2}{*}{ AZ-101 [6] } & $<4$ & 81 & 0 & 81 & 9.1 & \multirow{2}{*}{$53 \%$} \\
\hline & & 65 & 153 & 0 & 153 & 4.3 & \\
\hline \multirow{6}{*}{ DM100 } & \multirow{2}{*}{$\begin{array}{l}\text { SRS Sludge } \\
\text { Batch } 4 \text { [11] }\end{array}$} & 0 & 12.6 & 0 & 12.6 & 6.6 & \multirow{2}{*}{$48 \%$} \\
\hline & & 15.3 & 24.6 & 0 & 24.6 & 3.4 & \\
\hline & \multirow{2}{*}{$\begin{array}{c}\text { SRS Sludge } \\
\text { Batch } 19 \\
\text { Harrell } \\
\text { Industries }\end{array}$} & 0 & 11.7 & 2.5 & 14.2 & 6.9 & \multirow{2}{*}{$30 \%$} \\
\hline & & 11.8 & 22.3 & 2.5 & 24.8 & 4.8 & \\
\hline & \multirow{2}{*}{$\begin{array}{l}\text { SRS Sludge } \\
\text { Batch } 19 \\
\text { NOAH }\end{array}$} & 0 & 12.9 & 2.5 & 15.4 & 8.8 & \multirow{2}{*}{$41 \%$} \\
\hline & & 8.5 & 23.9 & 2.5 & 26.4 & 5.2 & \\
\hline
\end{tabular}


Table 4.2. Summary of Measured DM100 Parameters for Tests with SRS Sludge Batch 4.

\begin{tabular}{|c|c|c|c|c|c|c|c|c|}
\hline \multirow{2}{*}{\multicolumn{3}{|c|}{ Test }} & \multicolumn{3}{|c|}{5} & \multicolumn{3}{|c|}{7} \\
\hline & & & \multirow{2}{*}{$\frac{\text { AVG }}{1054}$} & \multirow{2}{*}{$\begin{array}{l}\text { MIN } \\
1021\end{array}$} & \multirow{2}{*}{$\begin{array}{c}\text { MAX } \\
1087\end{array}$} & \multirow{2}{*}{$\begin{array}{c}\text { AVG } \\
985 \\
\end{array}$} & \multirow{2}{*}{$\begin{array}{c}\text { MIN } \\
959\end{array}$} & \multirow{2}{*}{$\begin{array}{c}\text { MAX } \\
1057\end{array}$} \\
\hline \multirow{4}{*}{$\begin{array}{l}\mathrm{T} \\
\mathrm{E} \\
\mathrm{M}\end{array}$} & \multirow{4}{*}{ Electrode } & East Upper & & & & & & \\
\hline & & West Upper & 1070 & 1037 & 1088 & 1040 & 1022 & 1070 \\
\hline & & West Lower & 1084 & 1074 & 1098 & 1061 & 1052 & 1087 \\
\hline & & Bottom & 784 & 778 & 796 & 757 & 743 & 781 \\
\hline \multirow{10}{*}{$\begin{array}{c}\mathrm{E} \\
\mathrm{R} \\
\mathrm{A} \\
\mathrm{T} \\
\mathrm{U} \\
\mathrm{R} \\
\mathrm{E} \\
\text { (C) }\end{array}$} & \multirow{4}{*}{ Glass } & 27” from bottom & 1100 & 891 & 1150 & 1051 & 907 & 1112 \\
\hline & & $16 ”$ from bottom & 1128 & 1084 & 1147 & 1128 & 1108 & 1175 \\
\hline & & 10” from bottom & 1148 & 1125 & 1167 & 1155 & 1137 & 1200 \\
\hline & & 5” from bottom & 1152 & 1133 & 1169 & 1153 & 1136 & 1191 \\
\hline & \multirow{2}{*}{ Plenum } & Exposed & 505 & 430 & 541 & 474 & 444 & 507 \\
\hline & & Thermowell & 475 & 411 & 514 & 453 & 412 & 483 \\
\hline & \multirow{2}{*}{ Discharge } & Chamber & 1068 & 1047 & 1085 & 1029 & 1013 & 1066 \\
\hline & & Air Lift & 1044 & 1026 & 1085 & 1007 & 989 & 1057 \\
\hline & \multicolumn{2}{|c|}{ Film Cooler Outlet } & 287 & 272 & 294 & 270 & 257 & 289 \\
\hline & \multicolumn{2}{|c|}{ Transition Line Outlet } & 276 & 265 & 283 & 258 & 222 & 273 \\
\hline \multicolumn{3}{|c|}{ Lance Bubbling (lpm) } & 15.3 & 10.6 & 21.3 & 0.3 & 0.3 & 0.3 \\
\hline \multicolumn{3}{|c|}{ Melter Pressure (inches water) } & -1.03 & -2.47 & 0.71 & -1.09 & -1.78 & 0.31 \\
\hline \multicolumn{3}{|c|}{ Total Electrode Voltage (V) } & 46.2 & 42.5 & 49.1 & 32.0 & 28.1 & 47.9 \\
\hline \multicolumn{3}{|c|}{ Total Electrode Power $(\mathrm{kW})$} & 24.6 & 20.9 & 26.6 & 12.6 & 10.1 & 25.7 \\
\hline \multicolumn{3}{|c|}{ Plenum heater Power (kW) } & 0 & 0 & 0 & 0 & 0 & 0 \\
\hline \multicolumn{3}{|c|}{ Total Power $(\mathrm{kW})$} & 24.6 & 20.9 & 26.6 & 12.6 & 10.1 & 25.7 \\
\hline \multicolumn{3}{|c|}{ Glass Resistance (ohms) } & 0.087 & 0.078 & 0.093 & 0.082 & 0.077 & 0.089 \\
\hline
\end{tabular}


Table 4.3. Summary of Measured DM100 Parameters for SRS Sludge Batch 19 Tests.

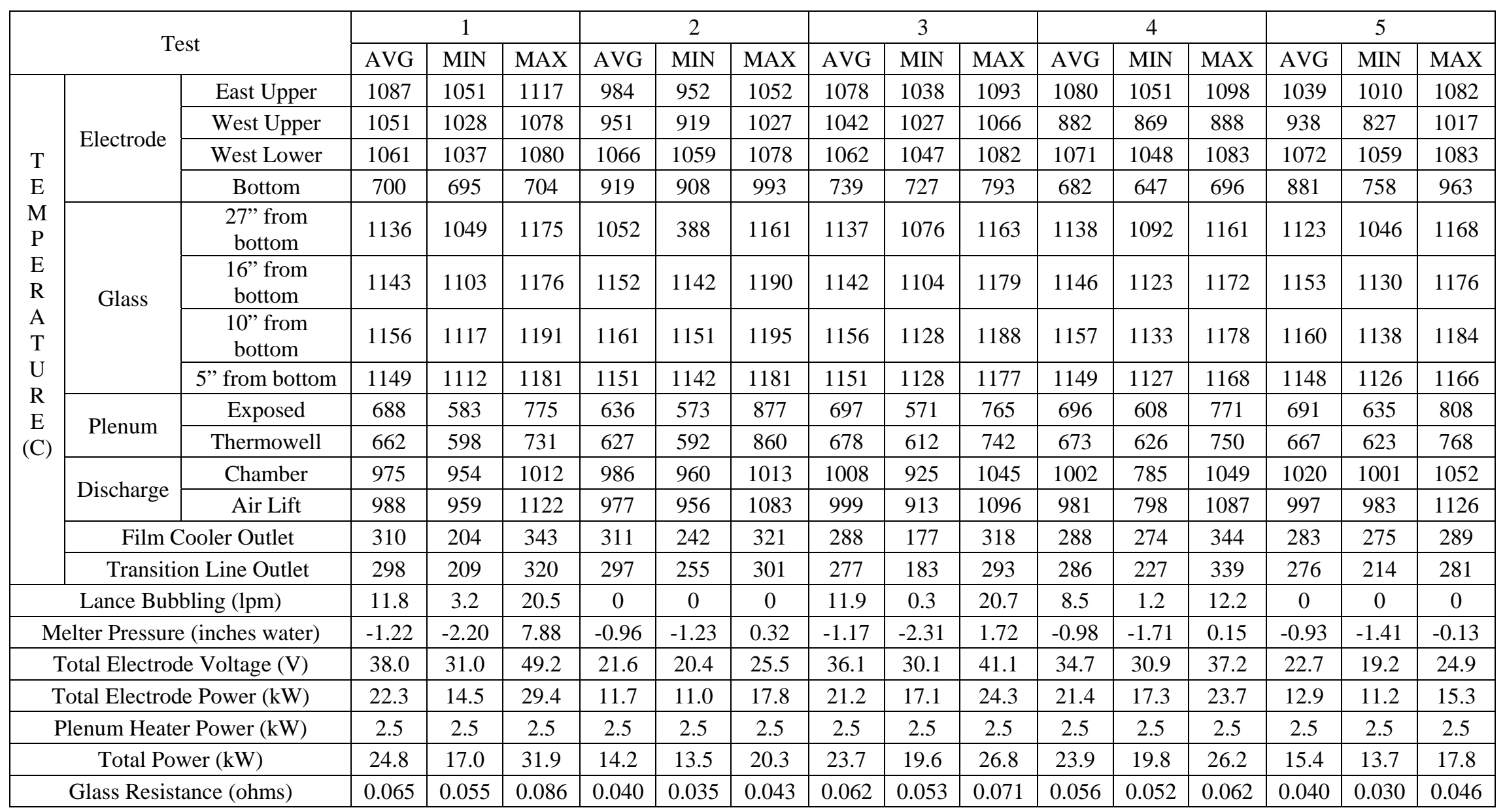


Table 6.1. Redox State of Glasses.

\begin{tabular}{|c|c|c|c|c|}
\hline Sludge Batch ID & Type of Test & Gas Flow & $\mathrm{Fe}^{2+} / \mathrm{Fe}_{\text {tot }}$ & $\begin{array}{c}\text { Performing } \\
\text { Organization }\end{array}$ \\
\hline $\begin{array}{c}\text { SB6 (with noble } \\
\text { metals) }\end{array}$ & Closed Crucible & None & 0.0 & SRNL \\
\hline $\begin{array}{c}\text { SB6 (without noble } \\
\text { metals) }\end{array}$ & Closed Crucible & None & 0.0 & SRNL \\
\hline SB6 & CEF Melter & None & 0.0 & SRNL \\
\hline SB6 & CEF Melter & Argon & 0.0 & SRNL \\
\hline SB19 (Harrell) & Closed Crucible & None & $<0.01$ & VSL \\
\hline SB19 (Harrell) & Closed Crucible & None & 0.01 & VSL \\
\hline SB19 (Harrell) & DM100 Melter & None & $<0.01$ & VSL \\
\hline SB19 (Harrell) & DM100 Melter & Air & $<0.01$ & VSL \\
\hline SB19 (Harrell) & DM100 Melter & Argon & 0.18 & VSL \\
\hline SB19 (NOAH) & DM100 Melter & None & 0.05 & VSL \\
\hline SB19 (NOAH) & DM100 Melter & Air & $<0.01$ & VSL \\
\hline
\end{tabular}


Table 7.1. Comparison of Particulate and Cesium Carryover During Tests With and Without Bubbling.

\begin{tabular}{|c|c|c|c|c|c|c|}
\hline Melter & Feed & $\begin{array}{l}\text { Bubbling } \\
\text { (lpm) }\end{array}$ & $\begin{array}{l}\text { \% Particulate } \\
\text { Carryover }\end{array}$ & $\begin{array}{c}\text { Increase in } \\
\text { Particulate } \\
\text { Carryover } \\
\text { Attributable to } \\
\text { Bubbling }\end{array}$ & $\begin{array}{l}\text { \% Cesium* } \\
\text { Carryover }\end{array}$ & $\begin{array}{c}\text { Increase in } \\
\text { Cesium } \\
\text { Carryover } \\
\text { Attributable to } \\
\text { Bubbling }\end{array}$ \\
\hline \multirow{2}{*}{ DM100 } & \multirow{2}{*}{ AZ-101 [12] } & $<0.1$ & 0.10 & \multirow{2}{*}{2.60} & 0.49 & \multirow{2}{*}{4.73} \\
\hline & & 5.7 & 0.26 & & 2.32 & \\
\hline \multirow{2}{*}{ DM1000 } & \multirow{2}{*}{$\begin{array}{c}\text { C-106/AY-102 } \\
{[3]}\end{array}$} & 0 & $<0.01$ & \multirow{2}{*}{$\mathrm{NC}$} & NA & \multirow{2}{*}{ NA } \\
\hline & & $61-97$ & 0.28 & & NA & \\
\hline \multirow{6}{*}{ DM1200 } & \multirow{2}{*}{ AZ-101 [4] } & $<4$ & 0.05 & \multirow{2}{*}{5.20} & 0.24 & \multirow{2}{*}{7.29} \\
\hline & & 47 & 0.26 & & 1.75 & \\
\hline & \multirow{2}{*}{ AZ-101 + frit [5] } & $<4$ & 0.13 & \multirow{2}{*}{1.77} & 0.36 & \multirow{2}{*}{3.67} \\
\hline & & 60 & 0.23 & & 1.32 & \\
\hline & \multirow{2}{*}{ AZ-101 [6] } & $<4$ & 1.18 & \multirow{2}{*}{0.44} & NA & \multirow{2}{*}{ NA } \\
\hline & & 65 & 0.78 & & NA & \\
\hline \multirow{7}{*}{ DM100 } & \multirow{2}{*}{ SRS SB4 [11] } & 0 & 0.26 & \multirow{2}{*}{8.19} & 2.48 & \multirow{2}{*}{2.86} \\
\hline & & 15.3 & 2.13 & & 7.09 & \\
\hline & \multirow{3}{*}{$\begin{array}{c}\text { SRS SB19 } \\
\text { Harrell Industries }\end{array}$} & 0 & 0.04 & \multirow{3}{*}{2.13} & NA & \multirow{3}{*}{ NA } \\
\hline & & 11.8 & 0.08 & & NA & \\
\hline & & 11.9 argon & 0.09 & & NA & \\
\hline & \multirow{2}{*}{$\begin{array}{l}\text { SRS SB19 } \\
\text { NOAH }\end{array}$} & 0 & 0.54 & \multirow{2}{*}{2.52} & NA & \multirow{2}{*}{ NA } \\
\hline & & 8.5 & 1.36 & & NA & \\
\hline
\end{tabular}

NC - Not Calculated

NA - Not Applicable due to the lack of cesium in the feed.

* Target Cs concentration in the glass for Ref [11] was $0.10 \mathrm{wt} \%$ and $0.08 \mathrm{wt} \%$ for Refs [12], [4] and [5]. 
Table 7.2. DM100 Melter Off-Gas Emission Results from Tests with SRS Sludge Batch 4.

\begin{tabular}{|c|c|c|c|c|c|c|c|c|c|}
\hline & \multicolumn{4}{|c|}{ Test 5} & \multicolumn{4}{|c|}{ Test 7} \\
\hline & & \multicolumn{4}{|c|}{$\begin{array}{c}\text { 02/22/07 16:40 - 17:40 } \\
101.0 \% \text { Isokinetic, } 13.9 \% \text { Moisture }\end{array}$} & \multicolumn{4}{|c|}{$\begin{array}{c}02 / 23 / 07 \text { 15:21 - 16:21 } \\
\text { 98.0\% Isokinetic, 5.5\% Moisture }\end{array}$} \\
\hline & & Feed Rate $^{\#}(\mathrm{mg} / \mathrm{min})$ & $\begin{array}{c}\text { Emissions } \\
\text { Rate (mg/min) }\end{array}$ & \% Feed & DF & $\begin{array}{c}\text { Feed Rate }^{\#} \\
\text { (mg/min) }\end{array}$ & $\begin{array}{c}\text { Emissions } \\
\text { Rate (mg/min) }\end{array}$ & \% Feed & $\mathrm{DF}$ \\
\hline \multirow{19}{*}{ 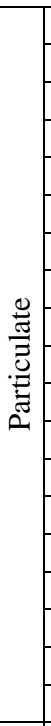 } & Total $^{\$}$ & 149244 & 3179 & 2.13 & 46.9 & 40703 & 106 & 0.26 & 385 \\
\hline & $\mathrm{Al}$ & 13063 & 184 & 1.41 & 71.1 & 3563 & 5.19 & 0.15 & 686 \\
\hline & $\mathrm{B}$ & 7054 & 136 & 1.93 & 51.8 & 1924 & 5.04 & 0.26 & 382 \\
\hline & $\mathrm{Ba}$ & 45 & 11.3 & 25.2 & 4.0 & 12 & 0.56 & 4.55 & 22.0 \\
\hline & $\mathrm{Ca}$ & 661 & 30.3 & 4.59 & 21.8 & 180 & 1.13 & 0.63 & 159 \\
\hline & $\mathrm{Cr}$ & 77 & 3.43 & 4.46 & 22.4 & 21 & 0.16 & 0.78 & 128 \\
\hline & Cs & 118 & 8.35 & 7.09 & 14.1 & 32 & 0.80 & 2.48 & 40.3 \\
\hline & $\mathrm{Fe}$ & 6978 & 245 & 3.50 & 28.5 & 1903 & 7.57 & 0.40 & 251 \\
\hline & $\mathrm{K}$ & 290 & 16.5 & 5.68 & 17.6 & 79 & 0.89 & 1.12 & 89.3 \\
\hline & $\mathrm{Li}$ & 2031 & 20.2 & 1.00 & 100 & 554 & 0.52 & 0.09 & 1058 \\
\hline & $\mathrm{Mg}$ & 264 & 14.7 & 5.56 & 18.0 & 72 & 0.56 & 0.78 & 128 \\
\hline & $\mathrm{Mn}$ & 1664 & 56.4 & 3.39 & 29.5 & 454 & 1.44 & 0.32 & 316 \\
\hline & $\mathrm{Na}$ & 11666 & 298 & 2.55 & 39.2 & 3182 & 11.7 & 0.37 & 273 \\
\hline & $\mathrm{Ni}$ & 608 & 28.2 & 4.63 & 21.6 & 166 & 0.97 & 0.58 & 171 \\
\hline & $\operatorname{Re}$ & 107 & 75.2 & 70.5 & 1.4 & 29 & 9.74 & 33.5 & 3.0 \\
\hline & $\mathrm{S}$ & 235 & 67.0 & 28.5 & 3.5 & 64 & 3.17 & 4.94 & 20.2 \\
\hline & $\mathrm{Si}$ & 19436 & 184 & 0.95 & 106 & 5301 & 5.14 & 0.10 & 1032 \\
\hline & $\mathrm{Ti}$ & 7 & 2.95 & 39.4 & 2.5 & 2 & 0.16 & 7.68 & 13.0 \\
\hline & $\mathrm{Zr}$ & 83 & 4.53 & 5.45 & 18.4 & 23 & $<0.10$ & $<0.01$ & $>230$ \\
\hline \multirow{2}{*}{$\underset{0}{\mathscr{0}}$} & B & 7054 & 15.1 & 0.21 & 467 & 1924 & 3.85 & 0.20 & 500 \\
\hline & $\mathrm{S}$ & 235 & 18.6 & 7.90 & 12.7 & 64 & 2.36 & 3.68 & 27.2 \\
\hline
\end{tabular}

$\$$ - From gravimetric analysis of filters and particulate nitric acid rinses.

\# - Feed rate calculated from target composition and steady state production rate. 


\section{Table 7.3. DM100 Melter Off-Gas Emission Results from Tests with SRS Sludge Batch 19} Simulant Prepared by Harrell Industries.

\begin{tabular}{|c|c|c|c|c|c|c|c|c|c|}
\hline & \multicolumn{4}{|c|}{ Test 1, $11.8 \mathrm{lpm}$ air bubbling } & \multicolumn{4}{|c|}{ Test 2, 0 lpm bubbling } \\
\hline & & \multicolumn{4}{|c|}{$\begin{array}{c}\text { 6/4/10 13:07 - 14:21 } \\
\text { 10.9\% Moisture; } 95.8 \% \text { Isokinetic }\end{array}$} & \multicolumn{4}{|c|}{$\begin{array}{c}\text { 6/10/10 17:48 - 18:48 } \\
\text { 4.7\% Moisture; } 105.4 \% \text { Isokinetic }\end{array}$} \\
\hline & & $\begin{array}{c}\text { Feed }^{\#} \\
(\mathrm{mg} / \mathrm{min})\end{array}$ & $\begin{array}{c}\text { Output } \\
\text { (mg/min) }\end{array}$ & $\begin{array}{c}\% \% \\
\text { Emitted }\end{array}$ & DF & $\begin{array}{c}\text { Feed }^{\#} \\
(\mathrm{mg} / \mathrm{min})\end{array}$ & $\begin{array}{c}\text { Output } \\
\text { (mg/min) }\end{array}$ & $\begin{array}{c}\% \\
\text { Emitted }\end{array}$ & DF \\
\hline \multirow{23}{*}{ 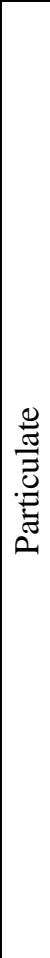 } & Total $^{\$}$ & 105963 & 86.1 & 0.08 & 1231 & 42059 & 17.7 & 0.04 & 2371 \\
\hline & $\mathrm{Al}$ & 7355 & 3.10 & 0.04 & 2370 & 2951 & 0.32 & 0.01 & 9263 \\
\hline & B & 2745 & 2.04 & 0.07 & 1343 & 1101 & 0.21 & 0.02 & 5195 \\
\hline & $\mathrm{Ba}$ & 67.0 & $<0.10$ & $<0.15$ & $>670$ & 26.9 & $<0.10$ & $<0.37$ & $>269$ \\
\hline & $\mathrm{Ca}$ & 821 & 1.14 & 0.14 & 720 & 330 & 0.52 & 0.16 & 635.2 \\
\hline & $\mathrm{Cl}^{*}$ & 10.2 & NA & NA & NA & 4.1 & NA & NA & NA \\
\hline & $\mathrm{Cr}$ & 90.2 & 0.36 & 0.40 & 250 & 36.2 & $<0.10$ & $<0.28$ & $>362$ \\
\hline & $\mathrm{Cu}$ & 28.5 & NA & NA & NA & 11.4 & NA & NA & NA \\
\hline & $\mathrm{F}^{*}$ & 2.6 & NA & NA & NA & 1.0 & NA & NA & NA \\
\hline & $\mathrm{Fe}$ & 5300 & 1.70 & 0.03 & 3110 & 2126 & $<0.10$ & $<0.00$ & $>21264$ \\
\hline & $\mathrm{K}$ & 231 & 1.11 & 0.48 & 207 & 92.6 & $<0.10$ & $<0.11$ & $>926$ \\
\hline & $\mathrm{Li}$ & 2054 & 1.35 & 0.07 & 1523 & 824 & $<0.10$ & $<0.01$ & $>8242$ \\
\hline & $\mathrm{Mg}$ & 91.8 & 0.14 & 0.16 & 638 & 36.8 & 0.18 & 0.48 & 207 \\
\hline & $\mathrm{Mn}$ & 565 & 0.10 & 0.02 & 5514 & 227 & $<0.10$ & $<0.04$ & $>2265$ \\
\hline & $\mathrm{Na}$ & 8601 & 13.47 & 0.16 & 639 & 3451 & 1.86 & 0.05 & 1857 \\
\hline & $\mathrm{Ni}$ & 102 & $<0.10$ & $<0.10$ & $>1022$ & 41.0 & $<0.10$ & $<0.24$ & $>410$ \\
\hline & $\mathrm{P}$ & 7.1 & $<0.10$ & $<1.42$ & $>71$ & 2.8 & $<0.10$ & $<3.53$ & $>28$ \\
\hline & $\mathrm{Pb}$ & 25.3 & NA & NA & NA & $\begin{array}{l}10.1 \\
\end{array}$ & NA & NA & NA \\
\hline & $\mathrm{S}^{*}$ & 22.2 & NA & NA & NA & 8.9 & NA & NA & NA \\
\hline & $\mathrm{Si}$ & 16038 & 9.04 & 0.06 & 1775 & 6435 & $<0.10$ & $<0.00$ & $>64349$ \\
\hline & $\mathrm{Ti}$ & 753 & 0.17 & 0.02 & 4382 & 302 & $<0.10$ & $<0.03$ & $>3021$ \\
\hline & $\mathrm{Zn}$ & 28.7 & NA & NA & NA & 11.5 & NA & NA & NA \\
\hline & $\mathrm{Zr}$ & 142 & $<0.10$ & $<0.07$ & $>1417$ & 56.8 & $<0.10$ & $<0.18$ & $>568$ \\
\hline \multirow{4}{*}{ రే } & B & 2745 & 11.32 & 0.41 & 242 & 1101 & 0.85 & 0.08 & 1295 \\
\hline & $\mathrm{Cl}$ & 10.2 & 10.26 & 101 & 1.0 & 4.1 & $<0.10$ & $<2.44$ & $>41$ \\
\hline & $F$ & 2.6 & $<0.10$ & $<3.92$ & $>26$ & 1.0 & $<0.10$ & $<9.77$ & $>10$ \\
\hline & $\mathrm{S}$ & 22.2 & 2.14 & 9.66 & 10.4 & 8.9 & 0.56 & 6.30 & 15.9 \\
\hline
\end{tabular}

$\$$ - From gravimetric analysis of filters and particulate nitric acid rinses

\# - Feed rate calculated from target composition and steady state production rate

* - Calculated from analysis of filter particulate by water dissolution

NA - Not Available

NC - Not Calculated 


\section{Table 7.3. DM100 Melter Off-Gas Emission Results from Tests with SRS Sludge Batch 19} Simulant Prepared by Harrell Industries (continued).

\begin{tabular}{|c|c|c|c|c|c|}
\hline & \multicolumn{4}{|c|}{ Test 3, 11.9 lpm argon bubbling } \\
\hline & & \multicolumn{4}{|c|}{$\begin{array}{c}\text { 6/17/10 18:08 - 19:08 } \\
\text { 12.2\% Moisture; } 105.9 \% \text { Isokinetic }\end{array}$} \\
\hline & & $\begin{array}{c}\text { Feed }^{\#} \\
(\mathrm{mg} / \mathrm{min})\end{array}$ & $\begin{array}{c}\text { Output } \\
\text { (mg/min) }\end{array}$ & $\begin{array}{c}\% \% \\
\text { Emitted }\end{array}$ & DF \\
\hline \multirow{23}{*}{ 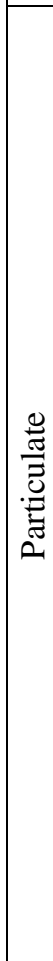 } & Total $^{\$}$ & 105874 & 91.6 & 0.09 & 1156 \\
\hline & $\mathrm{Al}$ & 7368 & 2.95 & 0.04 & 2499 \\
\hline & B & 2750 & 2.56 & 0.09 & 1072 \\
\hline & $\mathrm{Ba}$ & 67 & $<0.10$ & $<0.15$ & $>672$ \\
\hline & $\mathrm{Ca}$ & 823 & 0.47 & 0.06 & 1762 \\
\hline & $\mathrm{Cl}^{*}$ & 10 & 11.8 & NC & NC \\
\hline & $\mathrm{Cr}$ & 90 & 0.11 & 0.12 & 845 \\
\hline & $\mathrm{Cu}$ & 29 & NA & NA & NA \\
\hline & $\mathrm{F}^{*}$ & 3 & 0.14 & 4.7 & 21 \\
\hline & $\mathrm{Fe}$ & 5310 & 1.70 & 0.03 & 3121 \\
\hline & K & 231 & 1.38 & 0.60 & 168 \\
\hline & $\mathrm{Li}$ & 2058 & 1.68 & 0.08 & 1224 \\
\hline & $\mathrm{Mg}$ & 92 & $<0.10$ & $<0.11$ & $>920$ \\
\hline & $\mathrm{Mn}$ & 565 & $<0.10$ & $<0.02$ & $>5655$ \\
\hline & $\mathrm{Na}$ & 8617 & 14.83 & 0.17 & 581 \\
\hline & $\mathrm{Ni}$ & 102 & $<0.10$ & $<0.10$ & $>1024$ \\
\hline & $\mathrm{P}$ & 7 & $<0.10$ & $<1.41$ & $>71$ \\
\hline & $\mathrm{Pb}$ & 25 & NA & NA & NA \\
\hline & $\mathrm{S}^{*}$ & 22 & 5.7 & 25.9 & 3.9 \\
\hline & $\mathrm{Si}$ & 16068 & 8.84 & 0.06 & 1818 \\
\hline & $\mathrm{Ti}$ & 754 & 0.25 & 0.03 & 3003 \\
\hline & $\mathrm{Zn}$ & 29 & NA & NA & NA \\
\hline & $\mathrm{Zr}$ & 142 & $<0.10$ & $<0.07$ & $>1419$ \\
\hline \multirow{4}{*}{$\tilde{\mathscr{J}}$} & B & 2750 & 13.8 & 0.50 & 200 \\
\hline & $\mathrm{Cl}$ & 10 & 1.21 & 11.8 & 8.5 \\
\hline & $\mathrm{F}$ & 3 & $<0.10$ & $<3.91$ & $>26$ \\
\hline & $S$ & 22 & 3.38 & 15.24 & 6.6 \\
\hline
\end{tabular}




\section{Table 7.4. DM100 Melter Off-Gas Emission Results from Tests with SRS Sludge Batch 19} Simulant Prepared by NOAH Corporation.

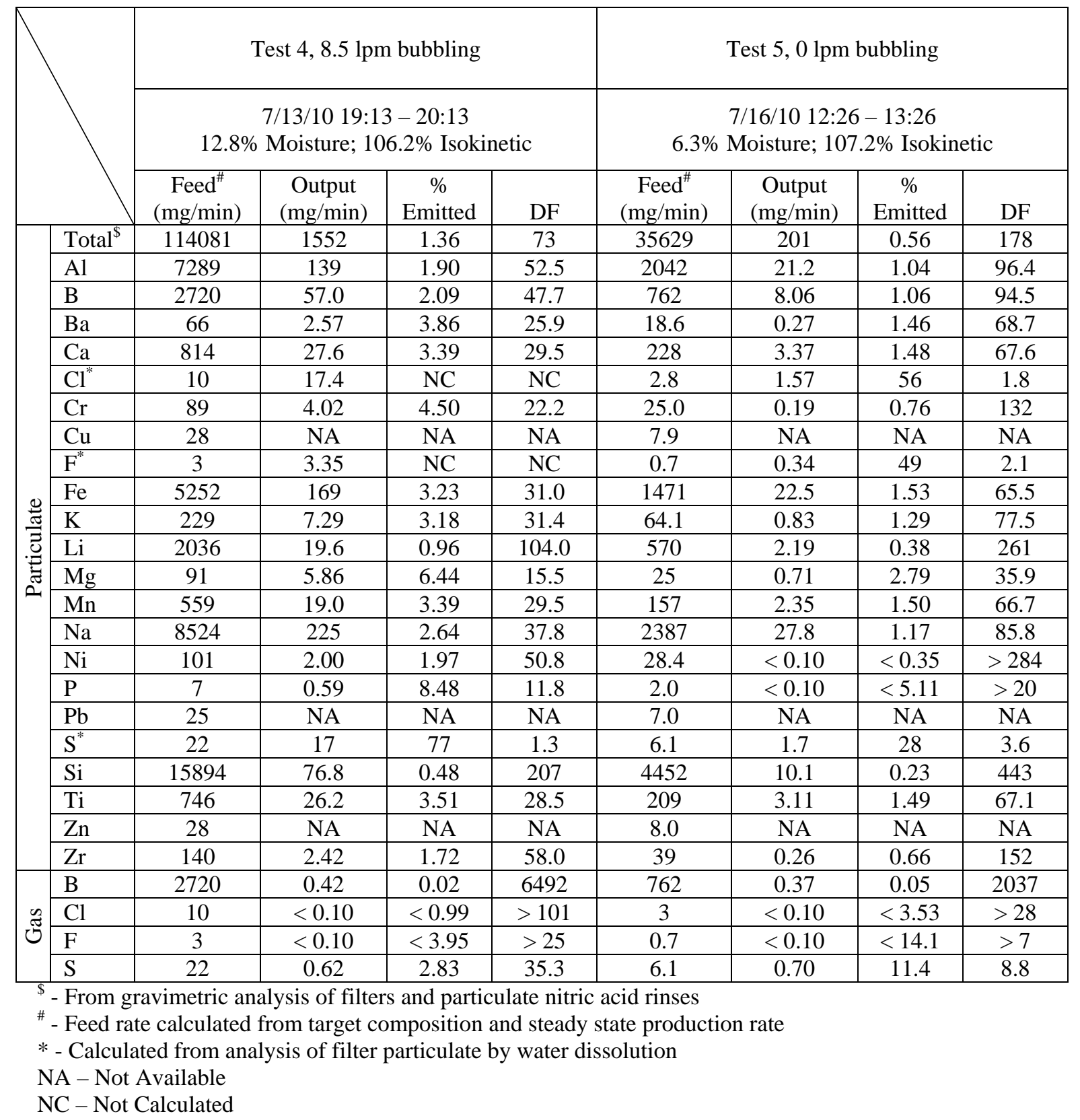


Table 7.5. DWPF Melter Decontamination Factors for Cesium and Total Particulate.

\begin{tabular}{|c|c|c|}
\hline- & Cesium & Total Particulate \\
\hline $\begin{array}{c}\text { Melter feed (mg/min) } \\
\text { IDMS data }\end{array}$ & 335 & Not reported \\
\hline $\begin{array}{c}\text { Melter off-gas (mg/min) } \\
\text { IDMS data }\end{array}$ & $2.54 \pm 1.39$ & $0.038 \% *$ \\
\hline $\begin{array}{c}\text { \% carryover } \\
\text { IDMS data }\end{array}$ & $0.76 \%$ & 2626 \\
\hline $\begin{array}{c}\text { DF } \\
\text { IDMS data }\end{array}$ & 132 & 69 \\
\hline DWPF DF design value & 15 & \\
\hline
\end{tabular}

* IDMS carryover value calculated from reported DF $\%$ carryover $=(1 / \mathrm{DF}) \times 100$ 
Table 8.1. Average Concentration and Range (ppmv) of Selected Species in Off-Gas Measured by FTIR Spectroscopy from SRS Sludge Batch 4 DM100 Tests.

\begin{tabular}{|c|c|c|c|c|}
\hline \multirow{2}{*}{} & \multicolumn{2}{|c|}{5} & \multicolumn{2}{c|}{7} \\
\cline { 2 - 5 } & Melter & Stack & Melter & Stack \\
\hline $\mathrm{N}_{2} \mathrm{O}$ & 236 & 45.1 & 95 & 18.5 \\
\hline $\mathrm{NO}$ & 1272 & 243 & 377 & 73.4 \\
\hline $\mathrm{NO}_{2}$ & 105 & 20 & 37 & 7.1 \\
\hline $\mathrm{NH}_{3}$ & 22 & 4.2 & 11 & 2.1 \\
\hline $\mathrm{H}_{2} \mathrm{O}[\%]$ & 34 & 6.5 & 11 & 2.1 \\
\hline $\mathrm{CO}_{2}[\%]$ & 1.067 & 0.204 & 0.481 & 0.094 \\
\hline Nitrous Acid & $<5.3$ & $<1.0$ & $<5.3$ & $<1.0$ \\
\hline Nitric Acid & $<5.3$ & $<1.0$ & $<5.3$ & $<1.0$ \\
\hline $\mathrm{CO}$ & 1078 & 206 & 368 & 71.5 \\
\hline $\mathrm{HCN}$ & $<5.3$ & $<1.0$ & $<5.3$ & $<1.0$ \\
\hline $\mathrm{HCl}$ & $<5.3$ & $<1.0$ & $<5.3$ & $<1.0$ \\
\hline $\mathrm{SO}$ & $<5.3$ & $<1.0$ & $<5.3$ & $<1.0$ \\
\hline $\mathrm{HF}$ & $<5.3$ & $<1.0$ & $<5.3$ & $<1.0$ \\
\hline
\end{tabular}

Note: Stack is point of measurement after particulate filtration. Melter concentration is calculated accounting for all dilutions including film cooler air. 
Table 8.2. Average Concentration and Range (ppmv) of Selected Species in Off-Gas Measured by FTIR Spectroscopy for SRS Sludge Batch 19 Tests.

\begin{tabular}{|c|c|c|c|c|c|c|c|c|c|c|}
\hline & \multicolumn{2}{|c|}{1} & \multicolumn{2}{c|}{2} & \multicolumn{2}{c|}{3} & \multicolumn{2}{c|}{4} & \multicolumn{2}{c|}{5} \\
\cline { 2 - 12 } & Melter & Stack & Melter & Stack & Melter & Stack & Melter & Stack & Melter & Stack \\
\hline $\mathrm{N}_{2} \mathrm{O}$ & 100 & 17.8 & 63 & 8.7 & 147 & 18.4 & 696 & 74.0 & 355 & 32 \\
\hline $\mathrm{NO}$ & 1805 & 323 & 1076 & 150 & 3022 & 378 & 3983 & 424 & 1805 & 162 \\
\hline $\mathrm{NO}_{2}$ & 411 & 73.5 & 117 & 16.3 & 252 & 31.5 & 256 & 27.2 & 156 & 14 \\
\hline $\mathrm{NH}_{3}$ & $<5.6$ & $<1.0$ & $<7.2$ & $<1.0$ & $<8.0$ & $<1.0$ & 12 & 1.3 & $<11.2$ & $<1.0$ \\
\hline $\mathrm{H}_{2} \mathrm{O}[\%]$ & 34 & 6.2 & 24 & 3.3 & 49 & 6.2 & 67 & 7.1 & 43 & 3.8 \\
\hline $\mathrm{CO}_{2}[\%]$ & 1.240 & 0.222 & 0.857 & 0.119 & 1.851 & 0.231 & 2.950 & 0.310 & 1.742 & 0.156 \\
\hline Nitrous Acid & $<5.6$ & $<1.0$ & $<7.2$ & $<1.0$ & $<8.0$ & $<1.0$ & $<9.4$ & $<1.0$ & $<11.2$ & $<1.0$ \\
\hline Nitric Acid & $<5.6$ & $<1.0$ & $<7.2$ & $<1.0$ & $<8.0$ & $<1.0$ & $<9.4$ & $<1.0$ & $<11.2$ & $<1.0$ \\
\hline $\mathrm{CO}$ & 443 & 79.3 & 257 & 35.7 & 585 & 73.1 & 1135 & 121 & 465 & 42 \\
\hline $\mathrm{HCN}$ & $<5.6$ & $<1.0$ & $<7.2$ & $<1.0$ & $<8.0$ & $<1.0$ & $<9.4$ & $<1.0$ & $<11.2$ & $<1.0$ \\
\hline $\mathrm{HCl}$ & $<5.6$ & $<1.0$ & $<7.2$ & $<1.0$ & $<8.0$ & $<1.0$ & $<9.4$ & $<1.0$ & $<11.2$ & $<1.0$ \\
\hline $\mathrm{SO} \mathrm{F}_{2}$ & $<5.6$ & $<1.0$ & $<7.2$ & $<1.0$ & $<8.0$ & $<1.0$ & $<9.4$ & $<1.0$ & $<11.2$ & $<1.0$ \\
\hline $\mathrm{HF}$ & 12 & 2.2 & 12 & 1.6 & 14 & 1.8 & $<9.4$ & $<1.0$ & $<11.2$ & $<1.0$ \\
\hline $\mathrm{H}_{2}$ & 341 & 61.0 & 244 & 34.0 & 216 & 27.0 & 103 & 11.0 & 56 & 5.0 \\
\hline
\end{tabular}

NA - Not applicable.

Note: Stack is point of measurement after particulate filtration. Melter concentration is calculated accounting for all dilutions including film cooler air. 


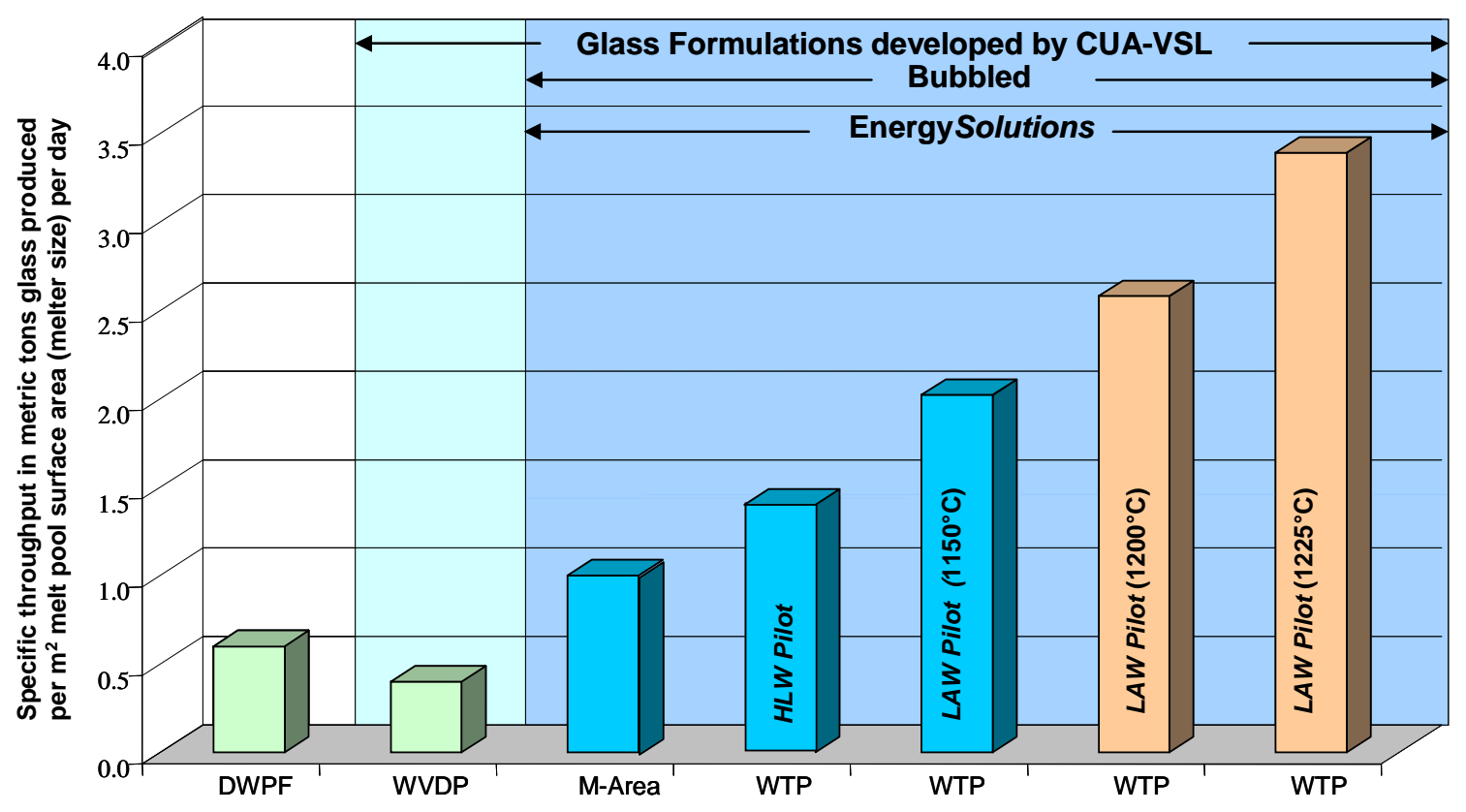

Figure 2.1. Comparison of glass production rates with conventional (DWPF and WVDP) and bubbled JHCMs and the further enhancements demonstrated by combining modest operating temperature increases with bubbling. 


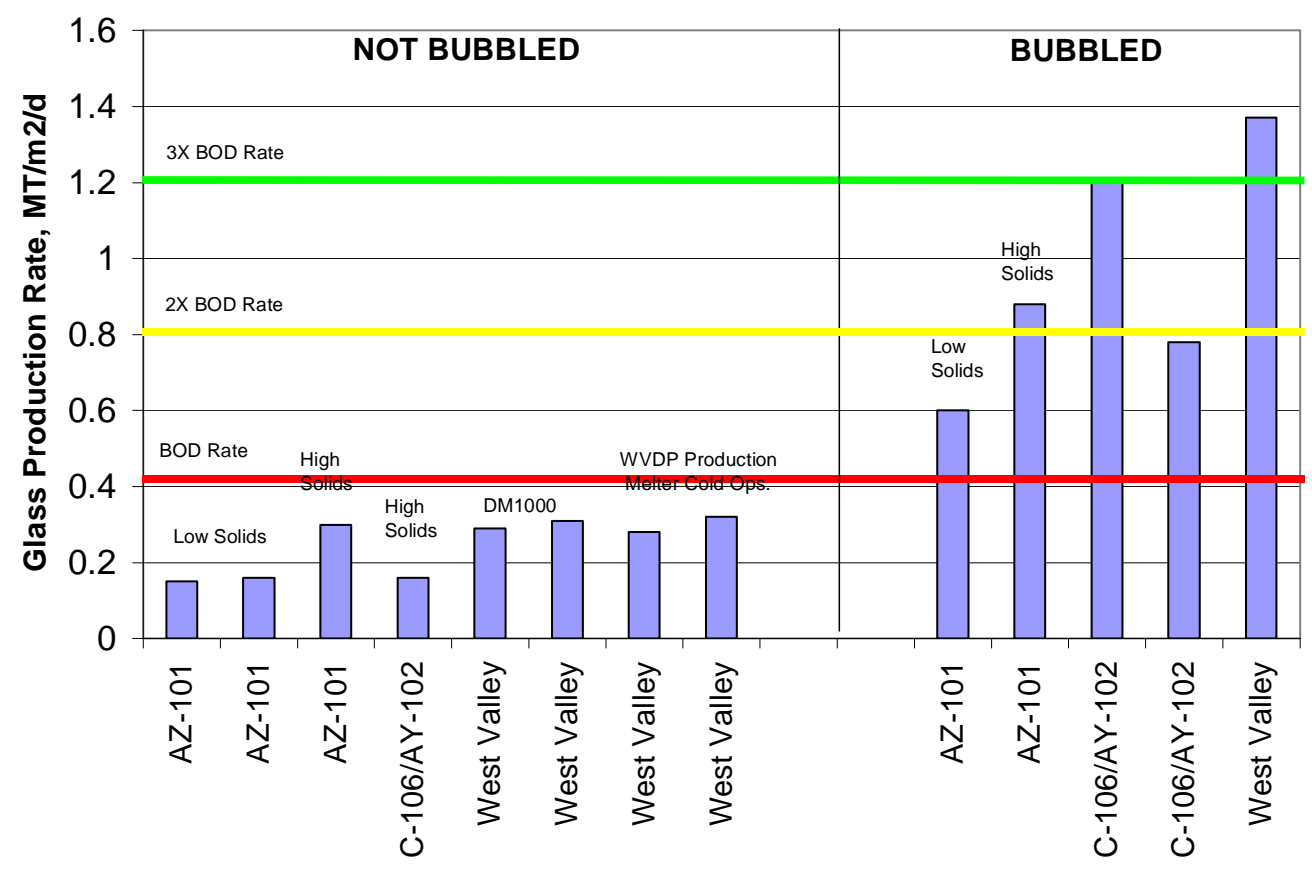

Figure 2.2. Comparison of glass production rates for Hanford WTP (AZ101, C106/AY102) and West Valley HLW feeds with and without bubbling determined on the DM1000 melter $\left(1.2 \mathrm{~m}^{2}\right)$. The DM1000 rates for West Valley feed without bubbling compares well to those obtained during WVDP cold commissioning runs. 


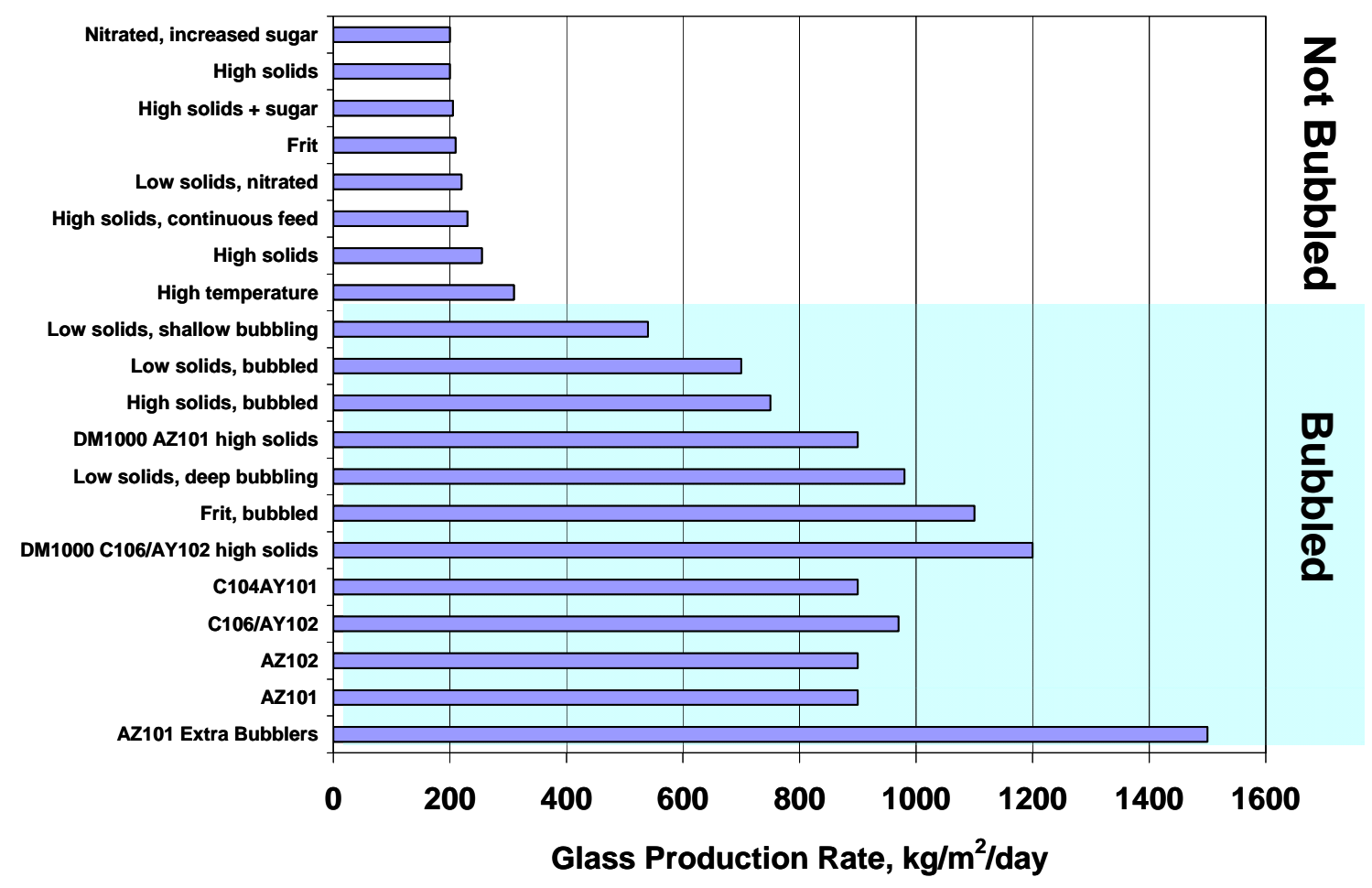

Figure 2.3. Effect of bubbling on glass production rate for a range of Hanford WTP HLW feeds (AZ101, AZ102, C106/AY102, C104/AY101) and feed conditions (solids content, frit, glass formers, nitrated feeds, etc.) determined on two different melters (DM1000 and DM1200, both $1.2 \mathrm{~m}^{2}$ ). Enhancement due to bubbling is large and robust. 


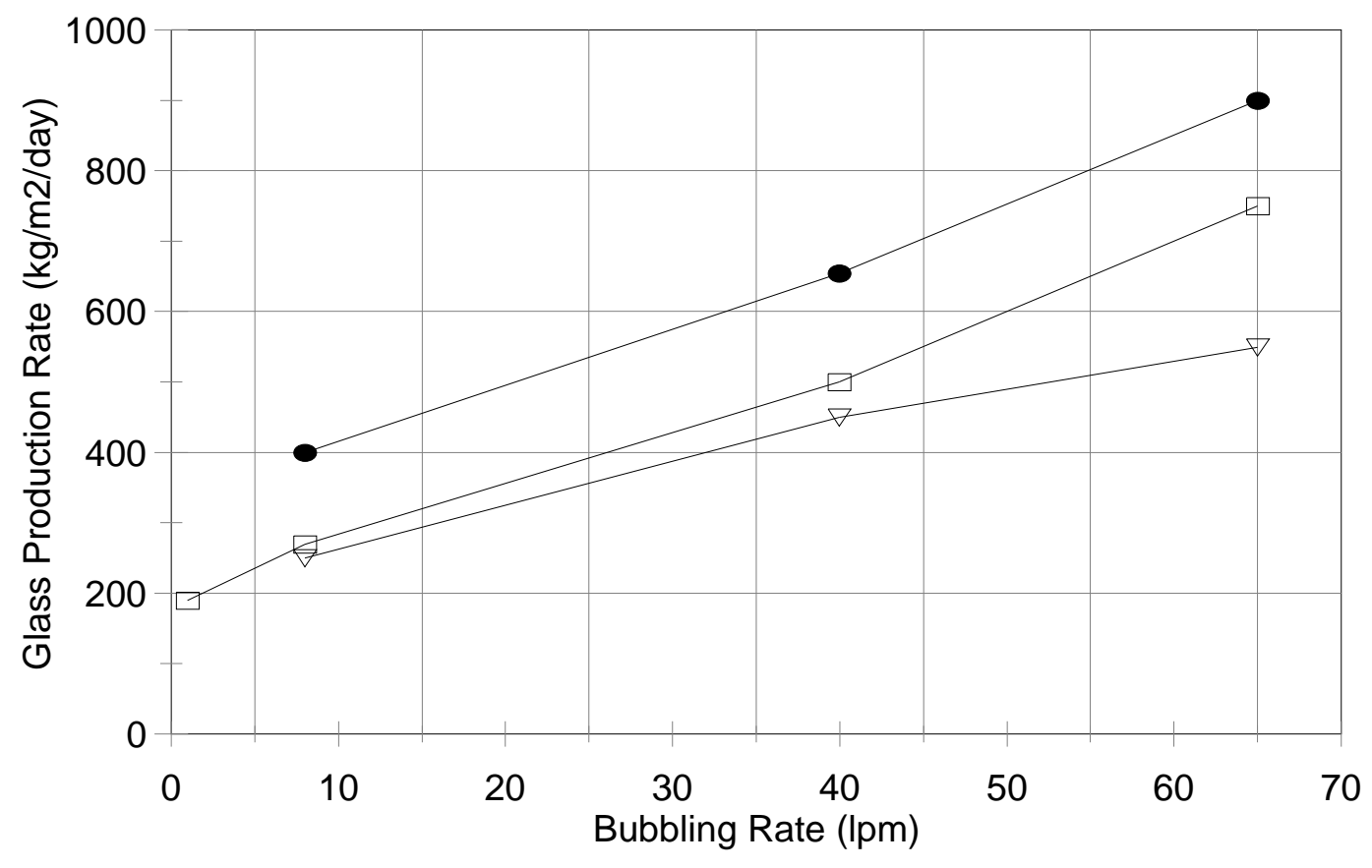

$$
\text { - } 530 \mathrm{~g} / \mathrm{l} \square 400 \mathrm{~g} / \mathrm{l} \nabla 300 \mathrm{~g} / \mathrm{l}
$$

Figure 2.4. Effect of bubbling rate on glass production rate for WTP HLW AZ101 feeds determined on the DM1200 melter $\left(1.2 \mathrm{~m}^{2}\right)$. Melter rate is controllable over a wide dynamic range by changing the bubbler flow rates. 


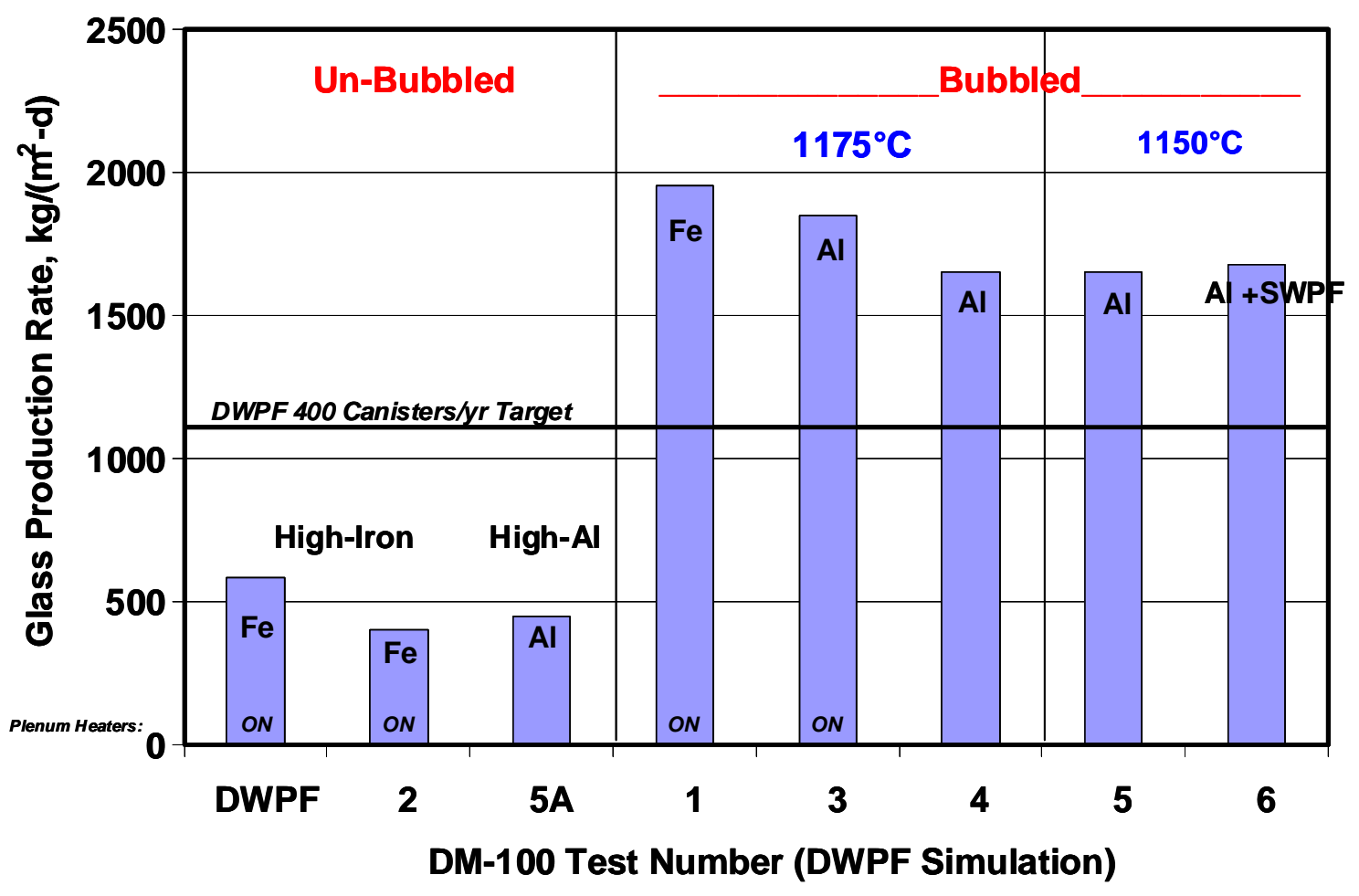

Figure 2.5. Results from DM 100 test melter campaigns conducted on simulated DWPF feeds. Both high iron and high aluminum type SRS HLW compositions were evaluated, with and without bubbling, with and without lid heaters, at two melt pool operating temperatures, and with the addition of SWPF product. All test cases with JHCM bubbling surpassed the required production rate to produce 400 canisters per year $\left(1.13 \mathrm{MT} / \mathrm{m}^{2} /\right.$ day $)$. 


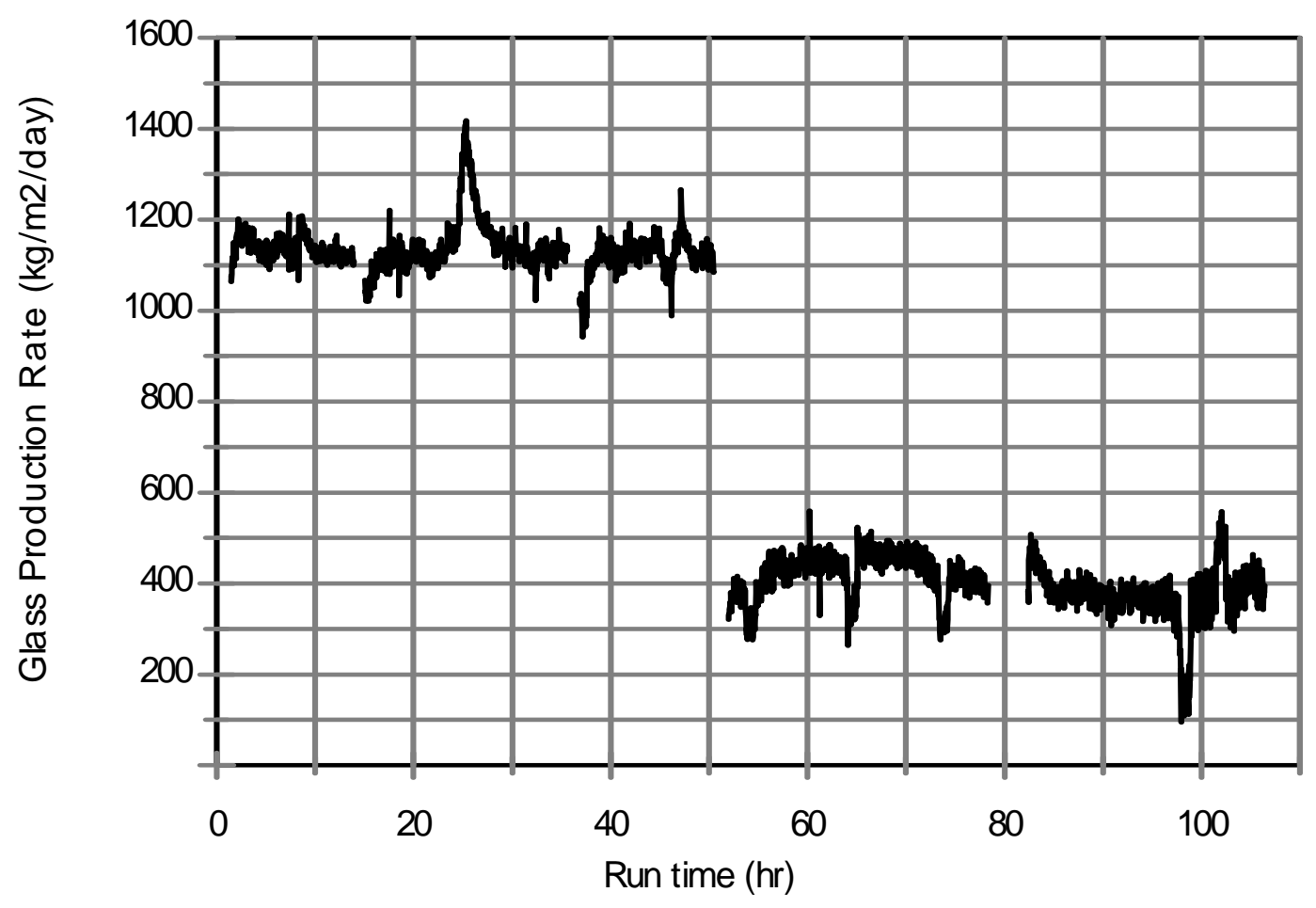

Figure 2.6. Glass production rates (hourly moving averages) for SRS Sludge Batch 19. Note: The latter portion of the test was conducted without bubbling. 
The Catholic University of America Vitreous State Laboratory
Engineering Study for DWPF Bubblers Final Report, VSL-10R1770-1, Rev. 0

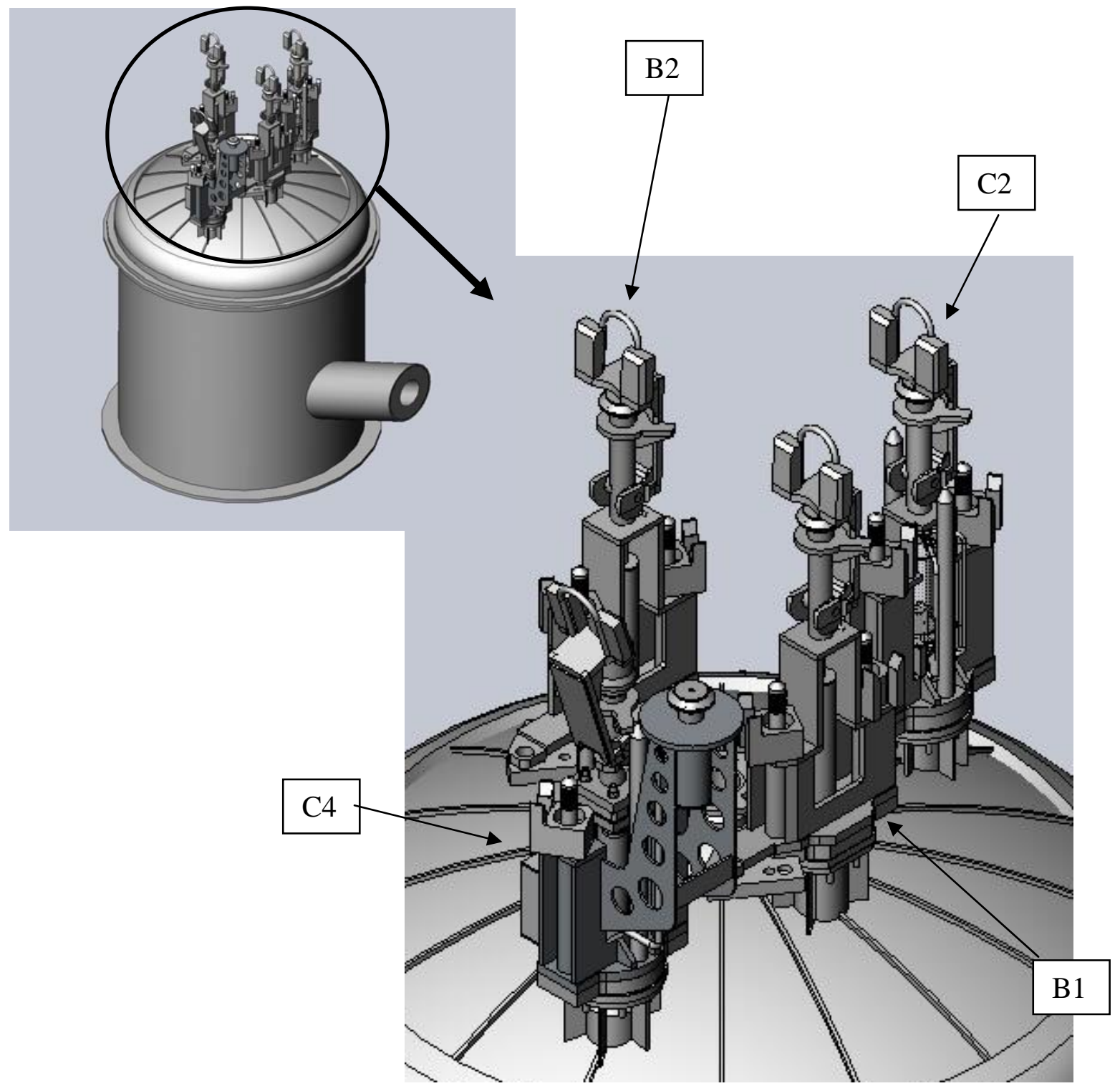

Figure 3.1. DWPF melter lid with bubblers installed (only bubbler assemblies shown). 


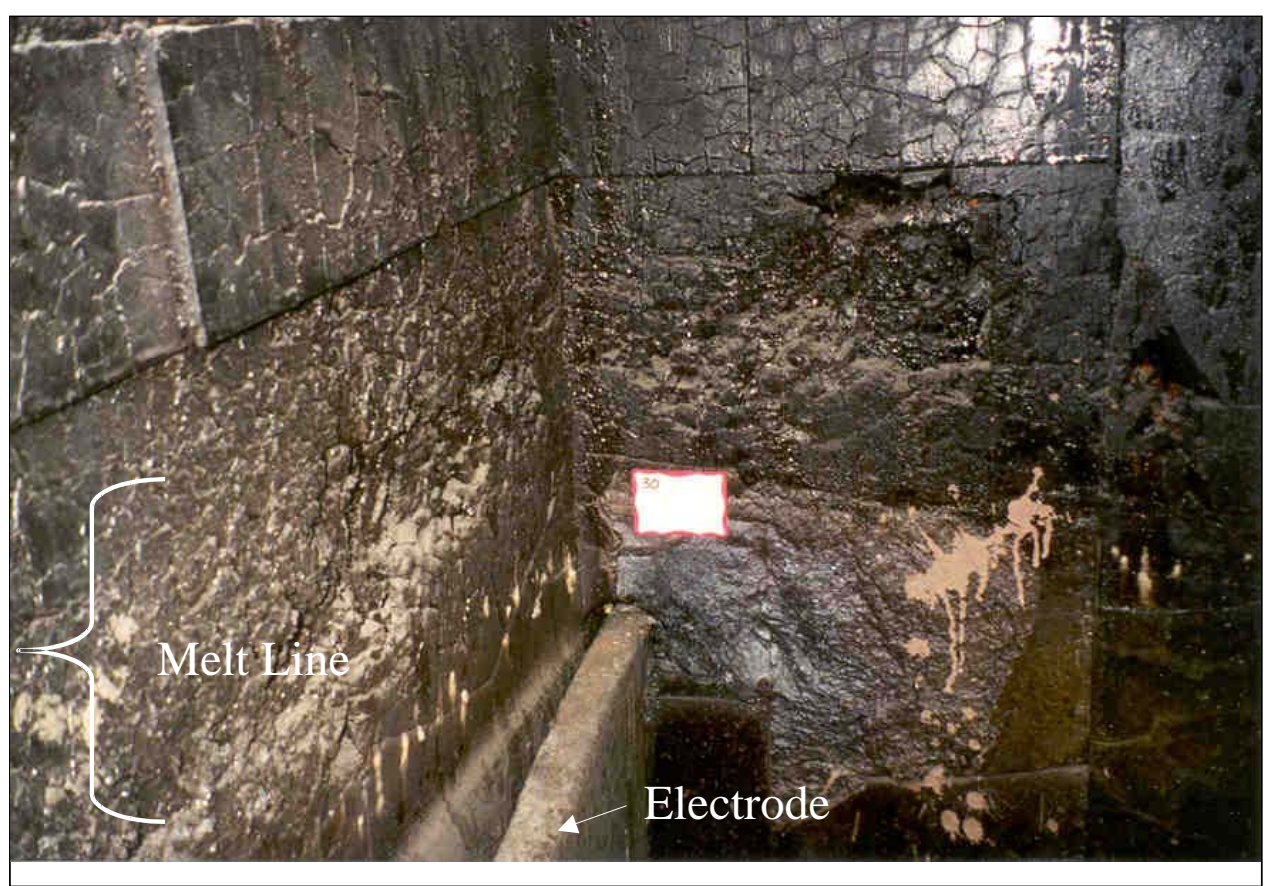

Figure 3.2. DM-5000A melter K-3 refractory at melt line after a year of operations. 


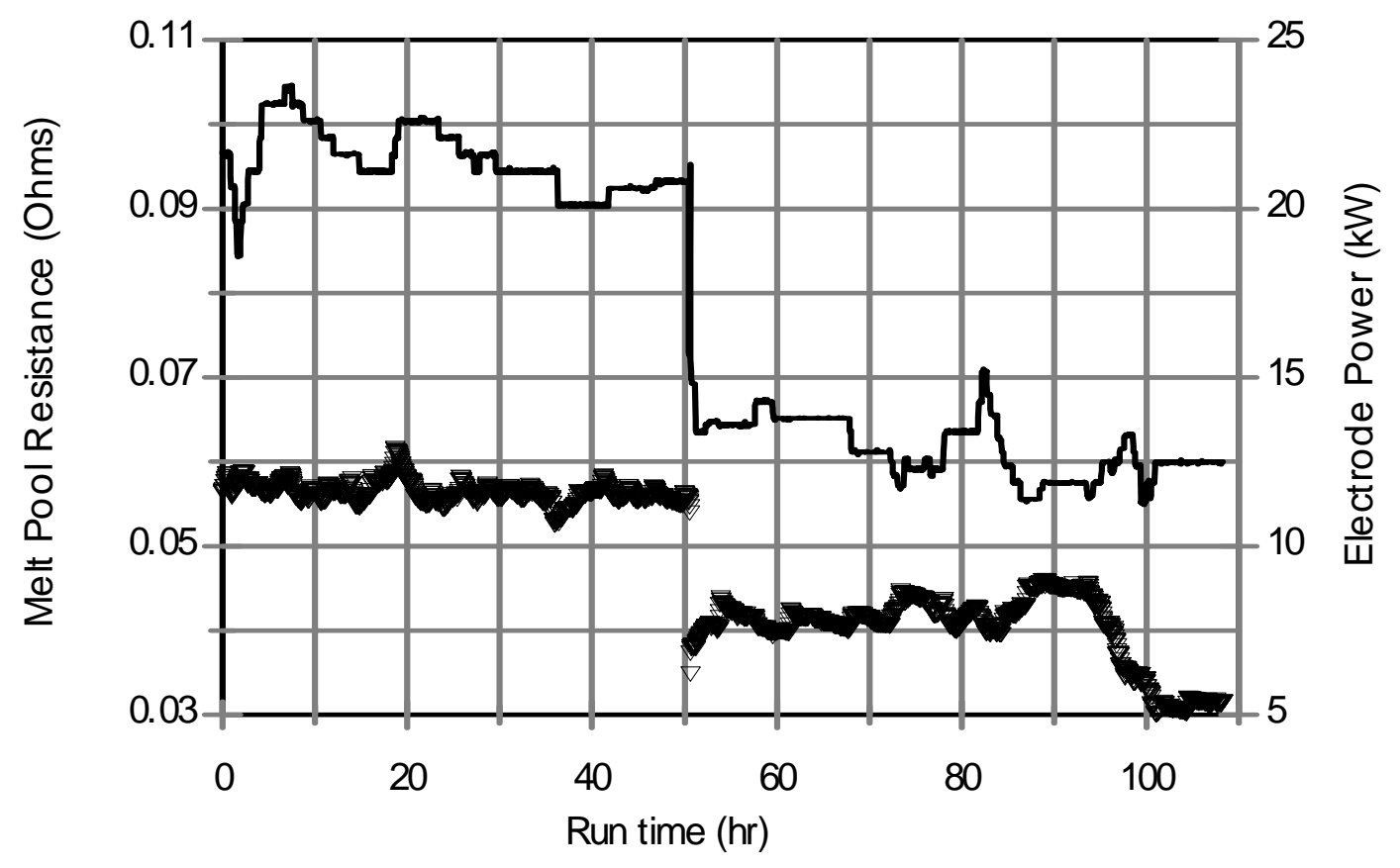

Figure 4.1. Melt pool resistance and total electrode power during processing SRS SB19. Note: The latter portion of the test was conducted without bubbling. 


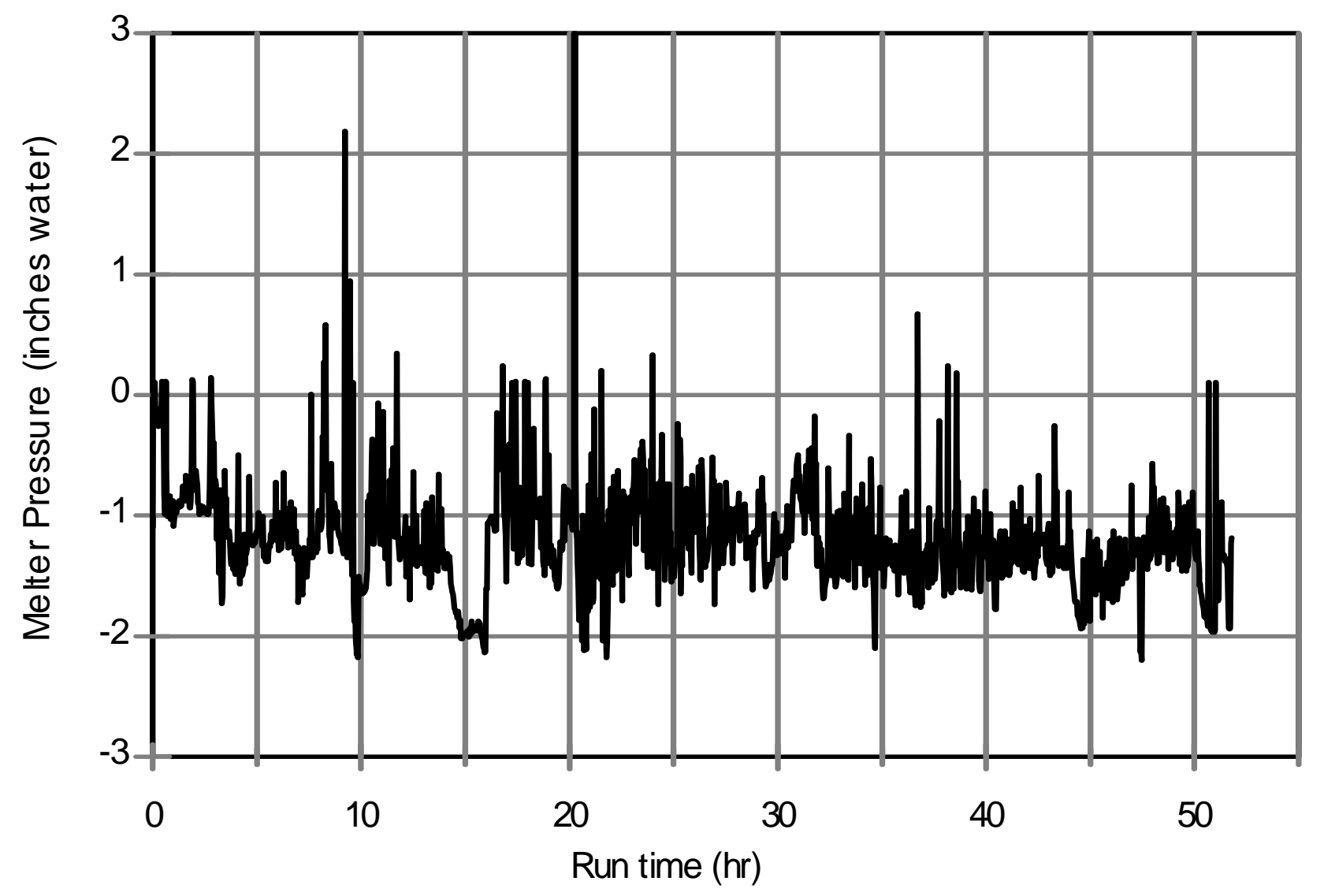

Figure 5.1. Melter Pressure recorded every 2 minutes during DM100 tests with SRS SB19 simulant produced by Harrell Industries. Test conducted with air bubbling. 


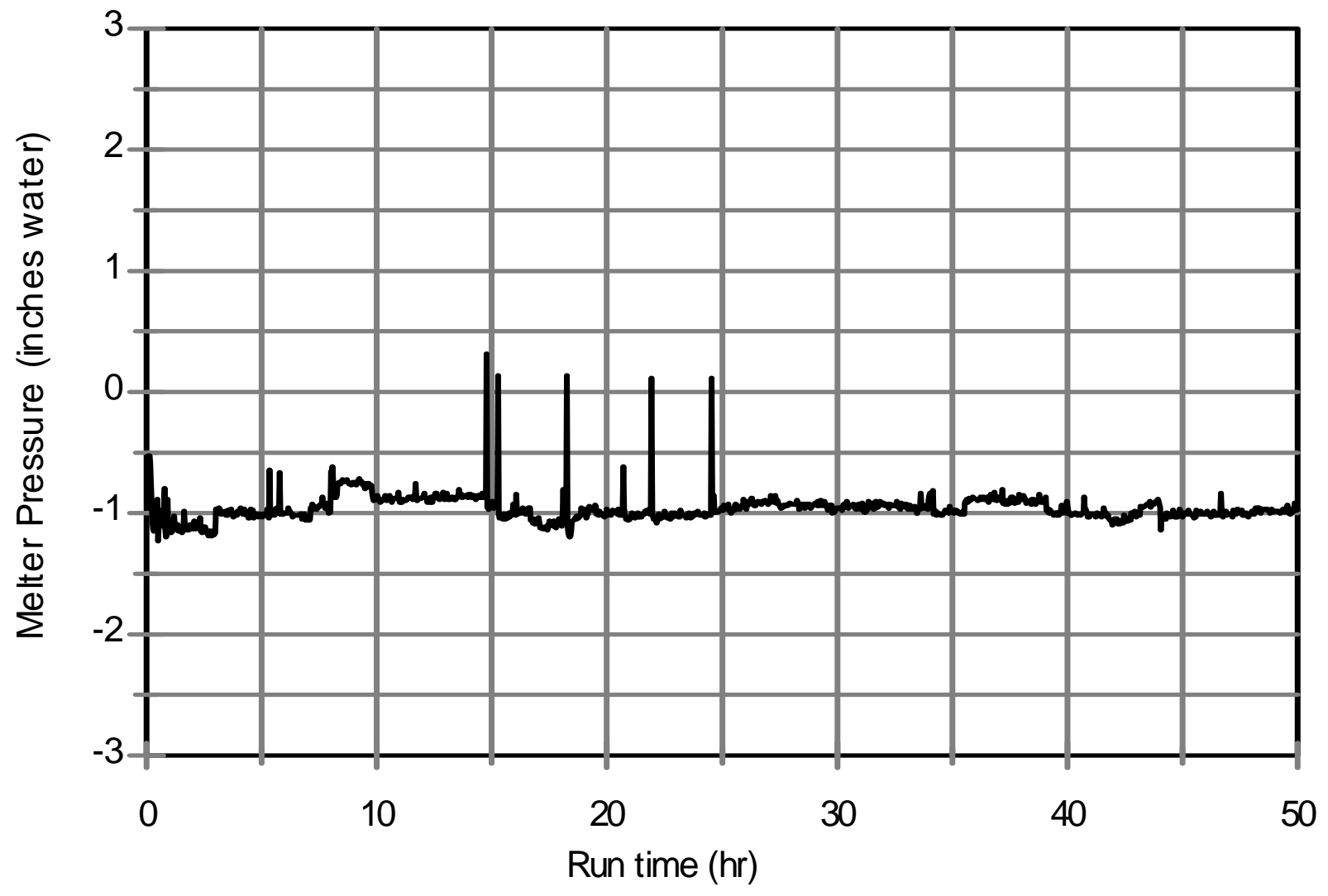

Figure 5.2. Melter Pressure recorded every 2 minutes during DM100 tests with SRS SB19 simulant produced by Harrell Industries. Test conducted without bubbling. 


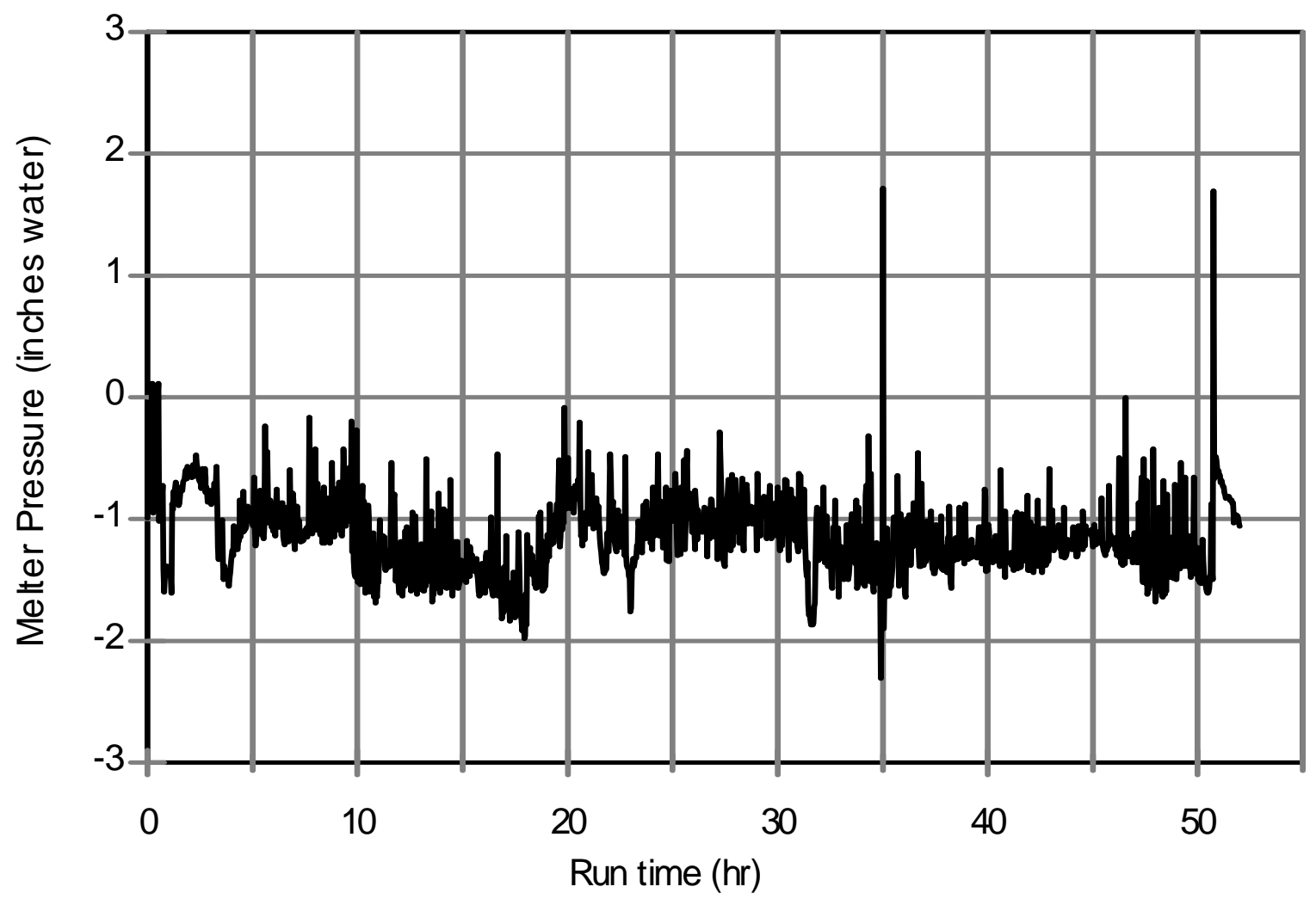

Figure 5.3. Melter Pressure recorded every 2 minutes during DM100 tests with SRS SB19 simulant produced by Harrell Industries. Test conducted with argon bubbling. 


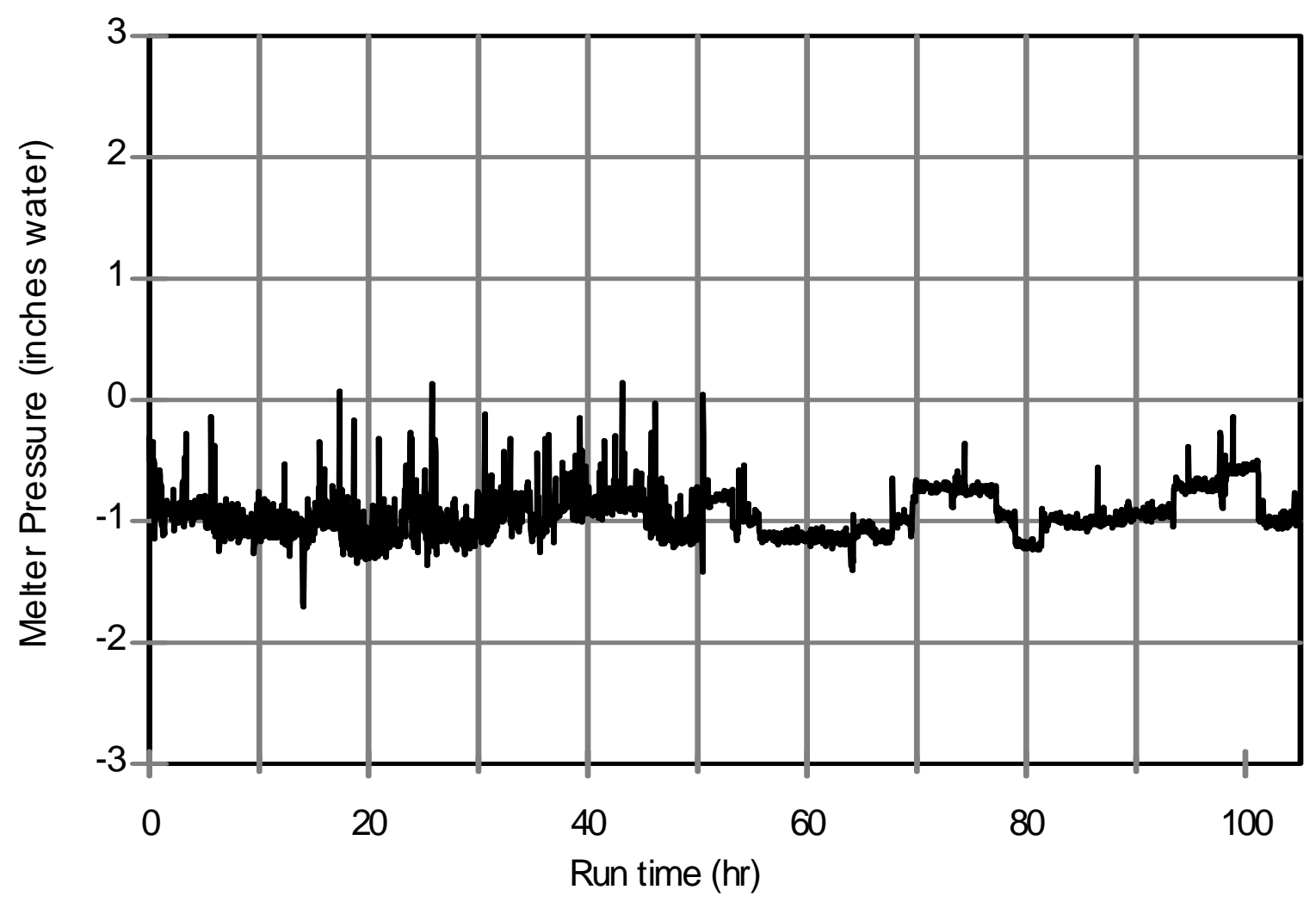

Figure 5.4. Melter Pressure recorded every 2 minutes during DM100 tests with SRS SB19 simulant produced by NOAH. Note first 50 hours Testing conducted with bubbling, last 50 hours conducted without bubbling. 


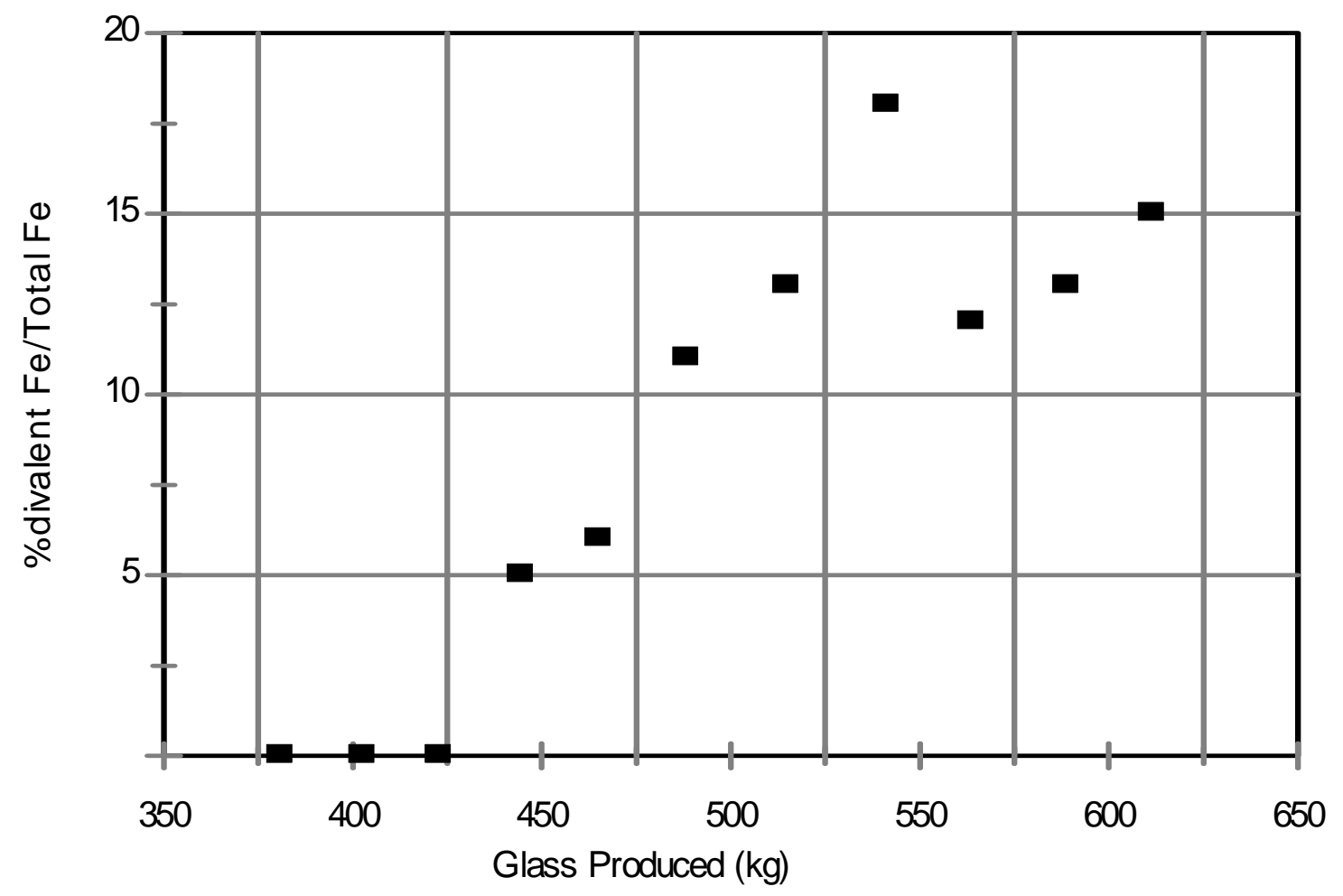

Figure 6.1. Measured divalent iron concentrations during DM100 tests with SRS SB19 simulant produced by Harrell Industries. Test conducted with argon bubbling. 


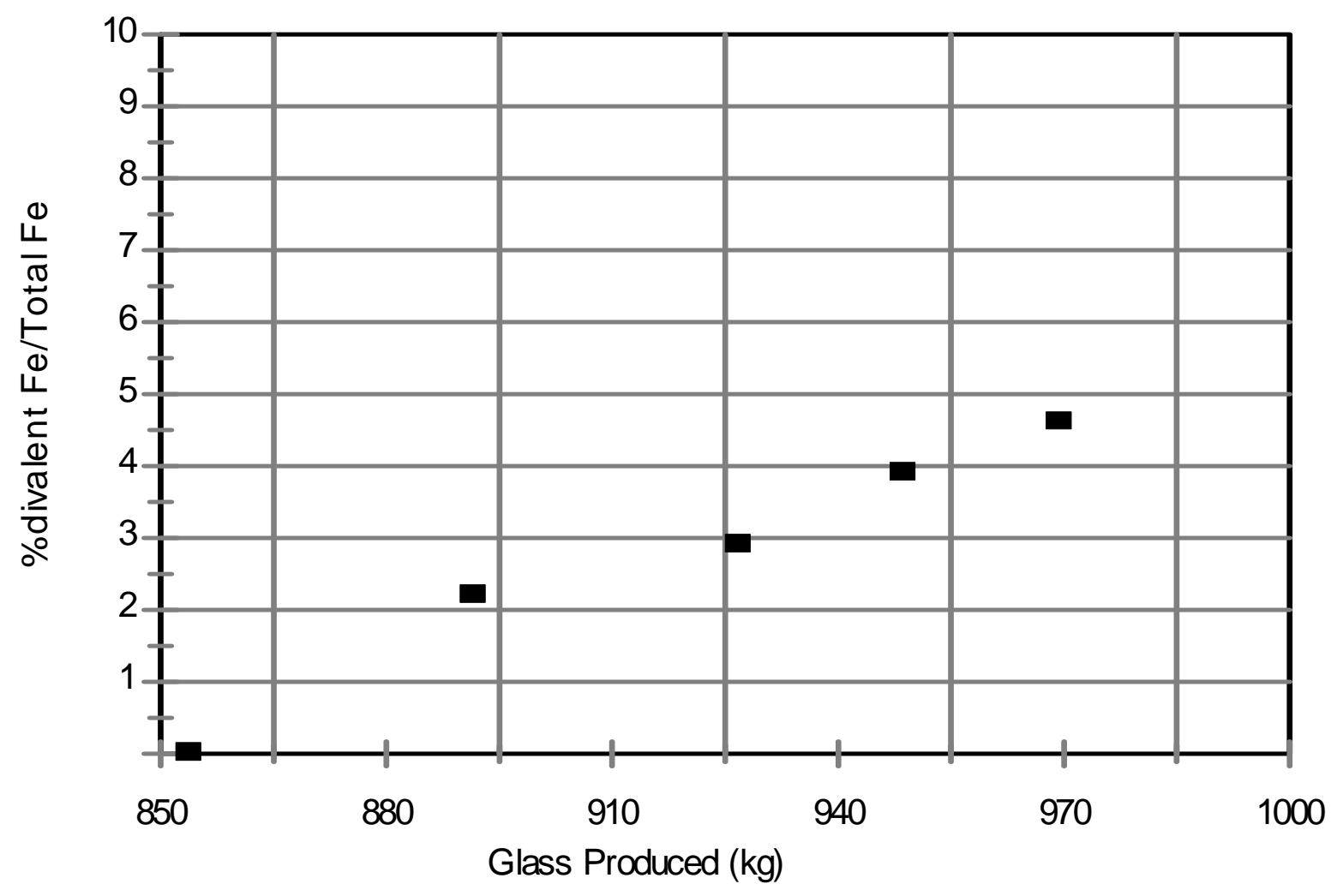

Figure 6.2. Measured divalent iron concentrations during DM100 tests with SRS SB19 simulant produced by NOAH. Test conducted without bubbling. 


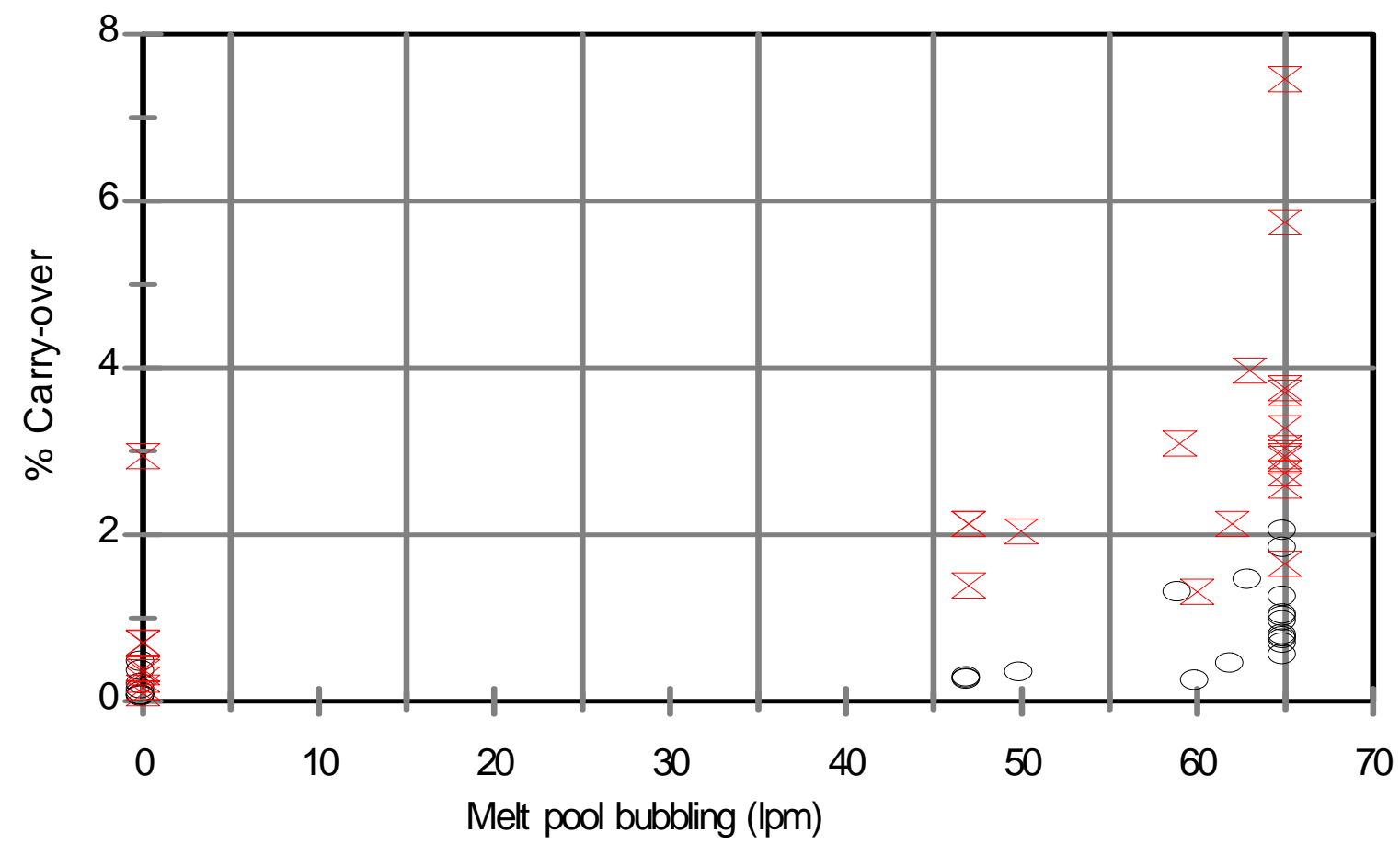

$$
\text { - Solids } \mathbf{Z} \text { Cs }
$$

Figure 7.1. Measured Carryover from the DM1200 while processing various Hanford simulated HLW streams. 


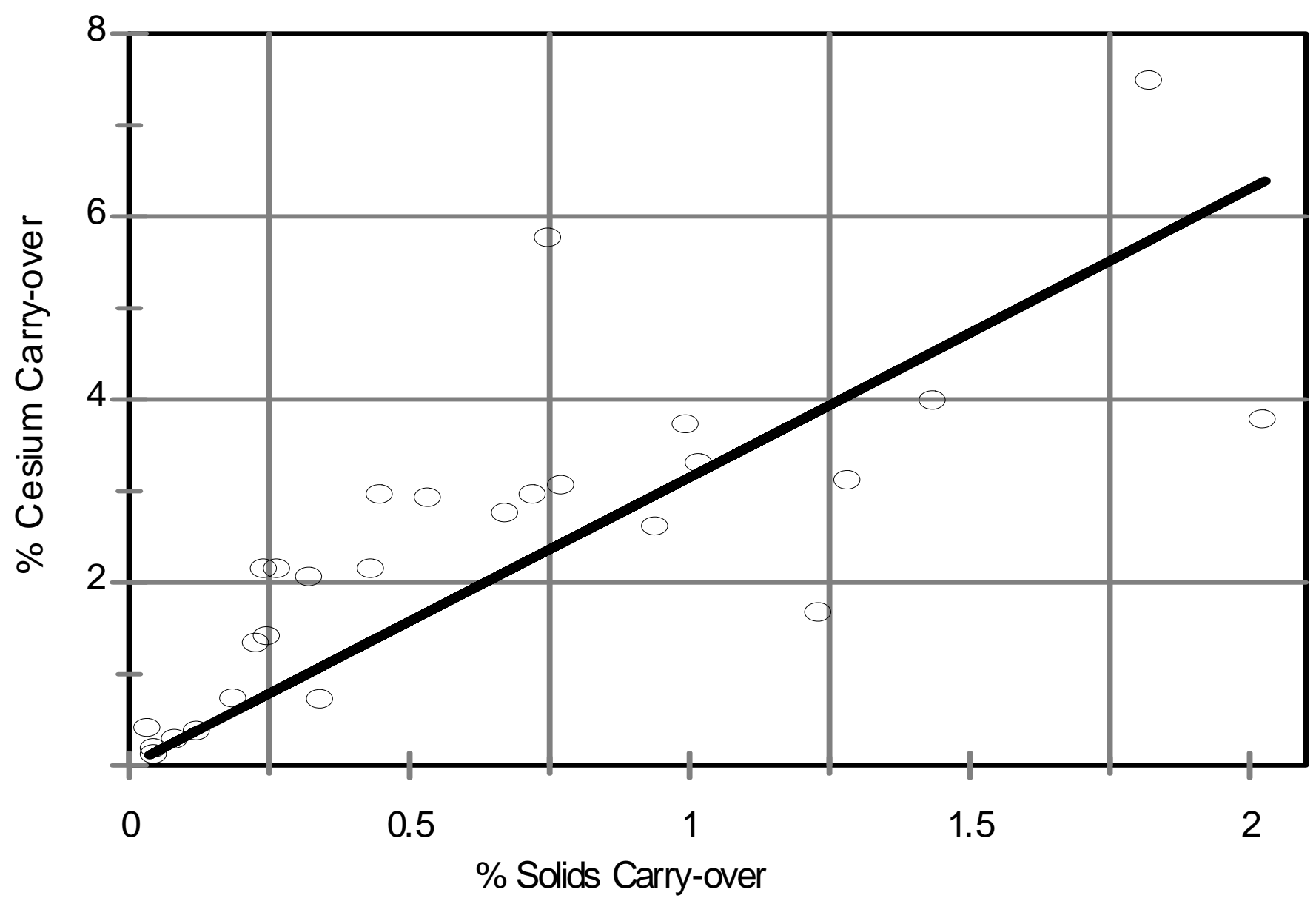

Figure 7.2. Relationship between solids and cesium carryover from the DM1200 while processing various Hanford simulated HLW streams. 